\title{
PHYSICAL AND HYDROLOGIC PROPERTIES OF ROCK OUTCROP SAMPLES AT YUCCA MOUNTAIN, NEVADA
}

by Lorraine E. Flint, Alan L. Flint, U.S. Geological Survey; Christopher A. Rautman, Sandia National Laboratories; and Jonathan D. Istok, Oregon State University

\section{U.S. GEOLOGICAL SURVEY}

Open-File Report 95-280

Prepared in cooperation with the

NEVADA OPERATIONS OFFICE,

U.S. DEPARTMENT OF ENERGY, under

Interagency Agreement DE-Al08-92NV10874 


\section{U.S. DEPARTMENT OF THE INTERIOR BRUCE BABBITT, Secretary \\ U.S. GEOLOGICAL SURVEY \\ Gordon P. Eaton, Director}

The use of trade, product, industry, or firm names is for descriptive purposes only and does not imply endorsement by the U.S. Government.

For additional information write to:

Chief, Earth Science Investigations

Program

Yucca Mountain Project Branch

U.S. Geological Survey

Box 25046, MS 421

Denver Federal Center

Denver, Colorado 80225
Copies of this report can be purchased from:

U.S. Geological Survey

Branch of Information Services

Box 25286

Denver, Colorado 80225 


\section{CONTENTS}

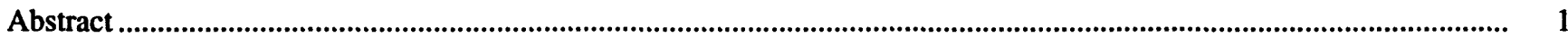

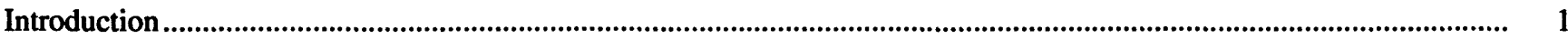

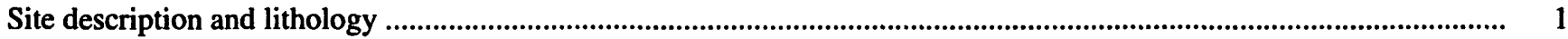

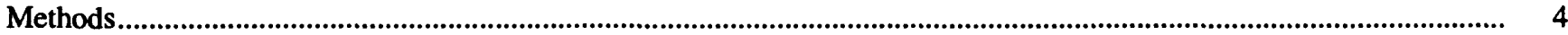

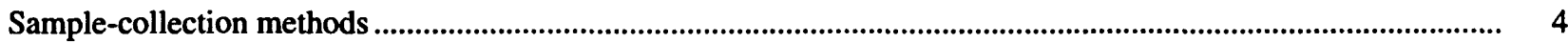

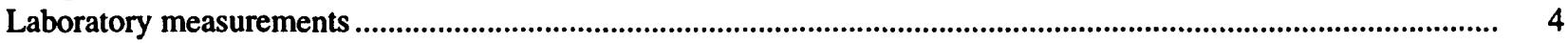

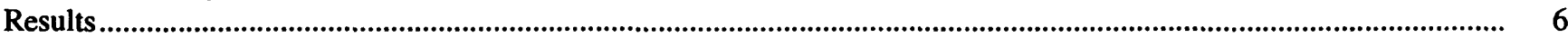

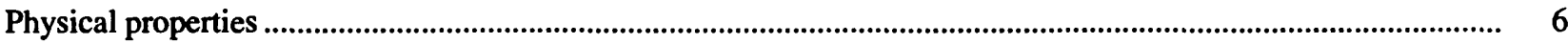

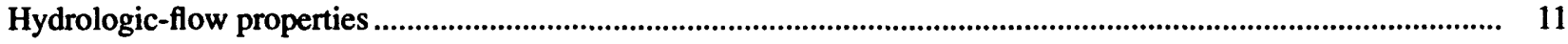

Estimates of hydrologic units for flow modeling ............................................................................................. 13

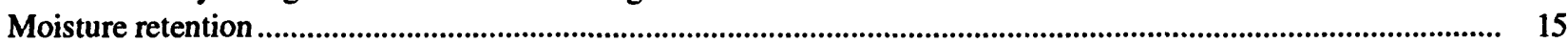

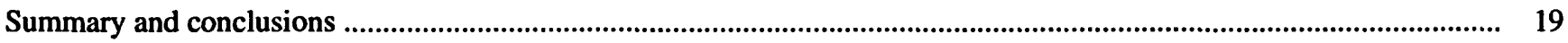

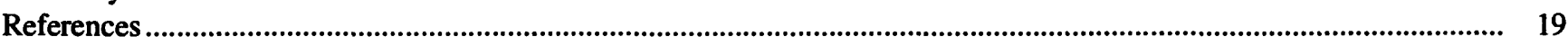

Appendix I: Data of physical properties and flow properties for eight outcrop transects............................................ 21

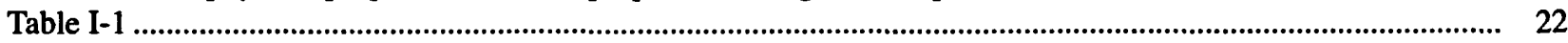

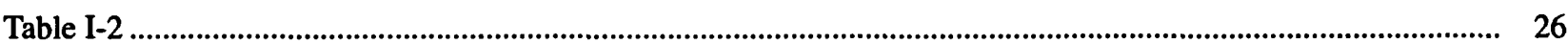

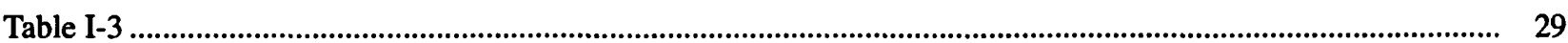

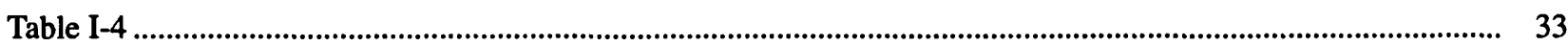

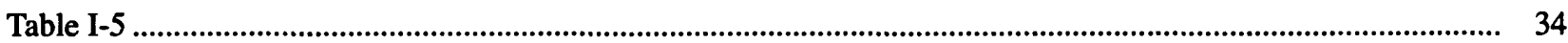

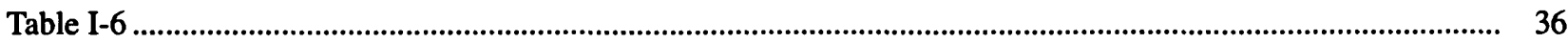

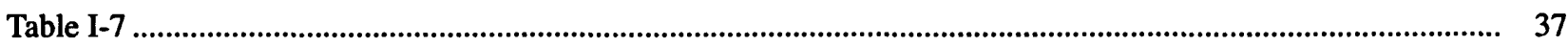

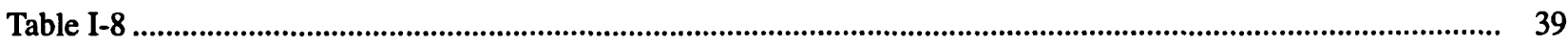

Appendix II: Moisture-retention measurements for subsamples of 41 outcrop transect cores..........................................4 41

Appendix III: Graphs of moisture-retention data and curve fits for subsamples of 41 outcrop transect cores.................... 45

\section{FIGURES}

1. Map showing study area, potential repository boundary, and location of surface outcrop-sampling transects

2. Conceptual stratigraphic column showing lithostratigraphic units ....................................................................... 3

3-12. Graphs showing:

3. Porosity and particle density for core samples from Solitario Canyon vertical transect........................... 7

4. Porosity and particle density for core samples from Busted Butte vertical transect ................................. 7

5. Porosity and particle density for core samples from Yucca Wash vertical transect ................................... 7

6. Porosity and particle density for core samples from Pagany Wash vertical transect ................................. 8

7. Porosity and particle density for core samples from Calico Hills Formation vertical transect ................... 8

8. Porosity and particle density for core samples from Yucca Crest horizontal transect................................ 8

9. Porosity and particle density for core samples from shardy base horizontal transect .............................. 9

10. Porosity and particle density for core samples from Topopah Spring Tuff caprock horizontal transect........................................................................................................................... 9

11. Relationship of porosity and saturated hydraulic conductivity for samples from (a) Solitario Canyon transect, and (b) Yucca Wash transect.

12. Relationship of porosity and van Genuchten parameters for (a) Alpha ( $\alpha$ ), and (b) $n$, for subsamples from 41 transect samples 


\section{TABLES}

1. Transects and their location, northing and easting according to Nevada State Plane Coordinate System, length, number of samples, and lithologic description

2. Descriptive statistics for each unit sampled for all transects for porosity, bulk density, and particle density calculated from $105^{\circ} \mathrm{C}$ oven-dry weights, and saturated hydraulic conductivity and sorptivity with number of samples

3. Nonlinear regression analysis performed for porosity and saturated hydraulic conductivity for the Solitario Canyon transect and the Yucca Wash transect

Descriptive statistics for all transects, combining lithology into hydrogeologic units for porosity, bulk density, and particle density calculated from $105^{\circ} \mathrm{C}$ oven-dry weights, and saturated hydraulic conductivity and sorptivity with number of samples

5. Properties and moisture-retention characteristics for subsamples from outcrop transect samples

6. Linear regressions of van Genuchten $\alpha$ and $n$ parameters versus porosity for welded, nonwelded, vitrophyre, and Calico Hills Formation samples

\section{CONVERSION FACTORS}

\begin{tabular}{rll}
\hline Multiply & By & To obtaln \\
\hline centimeter $(\mathrm{cm})$ & & \\
centimeter squared $\left(\mathrm{cm}^{2}\right)$ & 0.3937 & inch \\
cubic centimeter $\left(\mathrm{cm}^{3}\right)$ & 0.1550 & inch squared \\
cubic centimeter per cubic & 0.0610 & cubic inch \\
centimeter $\left(\mathrm{cm}^{3} / \mathrm{cm}^{3}\right)$ & 1.0000 & cubic inch per cubic inch \\
gram per cubic centimeter $\left(\mathrm{g} / \mathrm{cm}^{3}\right)$ & 0.0361 & pound per cubic inch \\
kilometer $(\mathrm{km})$ & 0.6214 & mile \\
megapascals $(\mathrm{MPa})$ & 10.0 & bars \\
meter $(\mathrm{m})$ & 3.2810 & feet \\
meter per second $(\mathrm{m} / \mathrm{s})$ & 3.2810 & feet per second \\
& 3.2810 & \\
meter per square root of second & &
\end{tabular}

Degree Celsius $\left({ }^{\circ} \mathrm{C}\right)$ may be converted to degree Fahrenheit $\left({ }^{\circ} \mathrm{F}\right)$ by using the following equation:

$$
{ }^{\circ} \mathrm{F}=9 / 5\left({ }^{\circ} \mathrm{C}\right)+32 \text {. }
$$

Degree Fahrenheit $\left({ }^{\circ} \mathrm{F}\right)$ may be converted to degree Celsius $\left({ }^{\circ} \mathrm{C}\right)$ by using the following equation:

$$
{ }^{\circ} \mathrm{C}=5 / 9\left({ }^{\circ} \mathrm{F}-32\right) \text {. }
$$




\title{
Physical and Hydrologic Properties of Rock Outcrop Samples at Yucca Mountain, Nevada
}

\author{
By Lorraine E. Flint, Alan L. Flint, Christopher A. Rautman, and Jonathan D. Istok
}

\section{Abstract}

A data set was developed from laboratory measurements of physical and hydrologic properties of surface outcrop samples collected from eight transects at Yucca Mountain, Nevada. Transects were located to represent the vertical and spatial variability of nonwelded and welded tuffs in major flow units. Horizontal variability was examined for several lithologic zones by conducting horizontal transects. Physical properties measured were bulk density, particle density, and porosity. Hydrologic properties were saturated hydraulic conductivity, sorptivity determined from measurements of imbibition, and moisture retention. Curves were fit to moisture-retention data using van Genuchten and Brooks and Corey equations.

Descriptive statistics of all rock properties showed major differences between nonwelded and welded units. Hydrogeologic units, based on physical and hydrologic properties, were determined to simplify flow modeling. Moistureretention curve-fit parameters were compiled for predicting unsaturated flow. Relationships of porosity to saturated hydraulic conductivity and van Genuchten parameters were examined.

\section{INTRODUCTION}

Studies are underway at Yucca Mountain, Nevada, to characterize physical and hydrologic conditions for a potential high-level radioactive-waste repository. Site characterization requires the development of three-dimensional models describing hydrogeologic units in terms of inputs for numerical models (physical and hydrologic-flow properties). It is also important to understand the spatial distribution of these properties, vertically and horizontally, in order to estimate values at unmeasured points. Deterministic processes of volcanism caused the initial formation of the rock units, and it is useful to be able to correlate rock properties with the more qualitative descriptions of rock lithology that occur on a larger scale (Rautman and Flint, 1992).

Preliminary data were collected to develop methods and evaluate spatial relations to determine sampling frequency. In addition, a data base was developed to provide some of the parameters needed for preliminary flow-modeling exercises. Surface transects of rock outcrops facilitated rapid collection of closely spaced samples of all units exposed at and around Yucca Mountain. This report presents the data collected, descriptive statistics for various units, preliminary hydrogeologic units, and analyses of porosity compared with flow properties.

There may be skepticism associated with the use of outcrop samples, many of which have undergone some degree of weathering, to represent subsurface material properties. However, there is evidence that physical and hydrologic properties measured on outcrop samples can be predicted in boreholes (Istok and others, 1994) even when using nonwelded rocks that weather more rapidly. In addition, subsurface borehole moisture conditions have been successfully modeled using parameters developed from measurements taken on surface outcrop samples (Flint and others, 1993).

\section{SITE DESCRIPTION AND LITHOLOGY}

Yucca Mountain is $130 \mathrm{~km}$ northwest of Las Vegas, Nevada (fig. 1), and is composed of approximately $6 \mathrm{~km}^{2}$ of ash-flow and ash-fall tuffs. These rocks have been tilted, faulted and eroded, and dip to the east-southeast, providing exposures of the tuffs of the Paintbrush Group and underlying tuffaceous beds of the Calico Hills Formation (fig. 2). At the north end of Yucca Mountain in Yucca Wash (fig. 1), most of the tuff of the Paintbrush Group is exposed south of Yucca Wash. The tuffs are composed of vitric to largely devitrified rhyolitic and quartz-latitic flows that range from nonwelded to densely welded rock with interbedded, nonwelded pumice and tuff. The Paintbrush Group is composed of two major thick flow units, the Tiva Canyon Tuff and the Topopah Spring Tuff. Geologic nomenclature used in this report is based on the units described by Scott and Bonk (1984). Between these members are thinly bedded and nonwelded units, as 


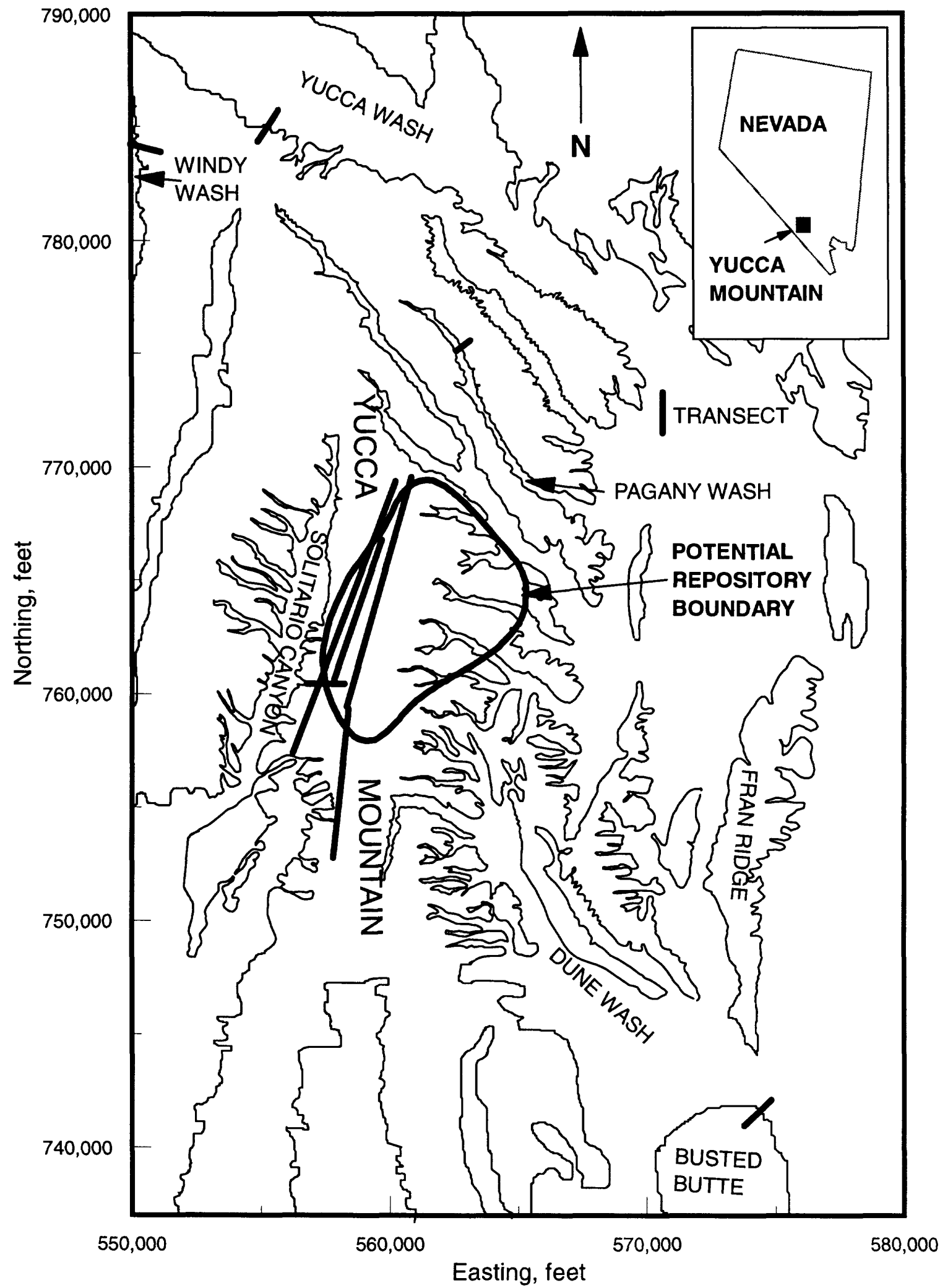

Figure 1. Study area, potential repository boundary, and location of surface outcrop-sampling transects. 


\begin{tabular}{|c|c|c|c|c|}
\hline \multicolumn{2}{|c|}{$\begin{array}{l}\text { Geologic } \\
\text { Unit }\end{array}$} & \multirow{2}{*}{$\begin{array}{c}\begin{array}{c}\text { Informal } \\
\text { Geologic } \\
\text { Nomenclature }\end{array} \\
\text { ccr - caprock }\end{array}$} & \multirow{2}{*}{\begin{tabular}{|c}
$\begin{array}{c}\text { Zonation of } \\
\text { Buesch and } \\
\text { others(1995) }\end{array}$ \\
Tpcrv \\
\end{tabular}} & $\begin{array}{c}\text { Thermal/ } \\
\text { Mechanical } \\
\text { Nomenclature } \\
\text { (Ortiz and } \\
\text { others, 1985) } \\
\end{array}$ \\
\hline \multirow{21}{*}{ 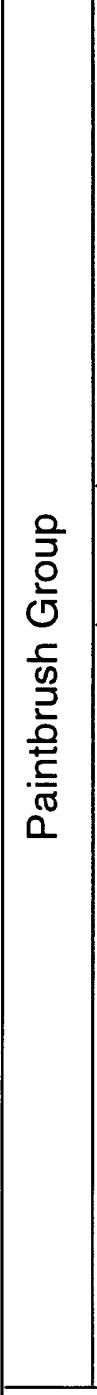 } & \multirow{8}{*}{$\begin{array}{l}\text { Tiva } \\
\text { Canyon } \\
\text { Tuff }\end{array}$} & & & \multirow{7}{*}{ TCw } \\
\hline & & cuc - upper cliff & Tpcm & \\
\hline & & cul - upper lithophysal & Tpcrl & \\
\hline & & cks - clinkstone & Tpcpmn & \\
\hline & & cll - lower lithophysal & Tpcpll & \\
\hline & & ch-hackly & Tpcplnh & \\
\hline & & cc-columnar & $\begin{array}{l}\text { Tpcplnc } \\
\text { Tpcpv3 }\end{array}$ & \\
\hline & & ccs - shardy base & $\begin{array}{l}\text { Tpcpv2 } \\
\text { Tpcpv1 }\end{array}$ & \multirow{5}{*}{ PTn } \\
\hline & Yucca Mountain Tuff & & & \\
\hline & Pah Canyon Tuff & & & \\
\hline & \multirow{11}{*}{$\begin{array}{l}\text { Topopah } \\
\text { Spring } \\
\text { Tuff }\end{array}$} & \multirow{2}{*}{ tn- upper nonwelded } & Tptrv3 & \\
\hline & & & Tptrv2 & \\
\hline & & tc - caprock & Tptrv1 & \multirow{4}{*}{ TSw1 } \\
\hline & & tr - rounded & Tptrn & \\
\hline & & \multirow{2}{*}{ tul - upper lithophysal } & Tptrl & \\
\hline & & & Tptpul & \\
\hline & & tnl - nonlithophysal & Tptpmn & \multirow{3}{*}{ TSw2 } \\
\hline & & tll - lower lithophysal & Tptpll & \\
\hline & & $\mathrm{tm}$ - mottled & Tptpln & \\
\hline & & tv - basal vitrophyre & Tptpv3 & TSw3 \\
\hline & & nonwelded base & $\begin{array}{l}\text { Tptpv2 } \\
\text { Tptpv1 }\end{array}$ & \multirow{2}{*}{$\mathrm{CHn} 1$} \\
\hline \multicolumn{2}{|c|}{ Calico Hills Formation } & Tht - zeolitized & & \\
\hline 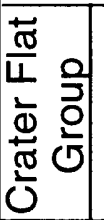 & $\begin{array}{l}\text { Prow } \\
\text { Pass } \\
\text { Tuff }\end{array}$ & pp - prow pass & & \\
\hline
\end{tabular}

Figure 2. Conceptual stratigraphic column showing lithostratigraphic units. 
well as the Yucca Mountain and Pah Canyon Tuffs. Underlying the Topopah Spring Tuff are the tuffaceous beds of the Calico Hills Formation, which are nonwelded rocks that have been zeolitized at the north end of Yucca Mountain, yet remain vitric toward the south end of the mountain. There are no vitric rocks in the tuffaceous beds of the Calico Hills Formation exposed on or near Yucca Mountain. The Prow Pass Tuff is the most recently deposited and, therefore, the uppermost flow unit within the Crater Flat Group, which underlies the Calico Hills Formation.

The Pah Canyon and Yucca Mountain Tuffs are relatively thick to the north in Yucca Wash and contain both welded and nonwelded intervals. However, the welded units thin rapidly southward toward the proposed repository, and only thin intervals of nonwelded rocks occur in the center of the potential repository block. Conversely, the Tiva Canyon Tuff thins to the north, conforms to the topography formed by older rocks, and is missing several areas in this region. Despite the significant thickness changes from north to south, some units exhibit consistent physical and hydrologic properties from Pagany Wash, south to Busted Butte (Istok and others, 1994).

\section{METHODS}

\section{Sample-Collection Methods}

Transects were located to sample all lithologic units exposed at Yucca Mountain (fig. 1), as well as to provide spatial coverage to assess the horizontal variability of several units. These comprised eight separate transects: five vertical transects, each covering several rock units, and three horizontal transects to evaluate the spatial variability of particular units. The location, length, number of samples, and general lithology for each transect are listed in table 1.

The vertical transects were located at (1) Solitario Canyon, at the southern end of the potential repository area, where the Tiva Canyon Tuff, bedded and nonwelded tuffs and upper Topopah Spring Tuff were sampled; (2) Busted Butte to the south, where the Topopah Spring Tuff was sampled; (3) Yucca Wash at the north end of Yucca Mountain, where the tuffs of the Paintbrush Group and Calico Hills Formation were sampled; (4) Windy Wash west of Yucca Mountain, where the entire section of the tuffaceous beds of Calico Hills were sampled; and (5) Pagany Wash, about three-fourths of the way up the wash, where the upper portion of the Tiva Canyon Tuff caprock

(fig. 1) is preserved.
The horizontal transects of selected lithologic units were conducted at (1) Solitario Canyon, sampling the nonwelded base of the Tiva Canyon Tuff (shardy base); (2) Solitario Canyon, sampling the vitric caprock of the Topopah Spring Tuff; and (3) Yucca Crest, sampling the upper-cliff unit of the Tiva Canyon Tuff. The base of the Tiva Canyon Tuff is a zone that transitions from the densely welded tuffs to the underlying nonwelded and bedded tuffs. This unit (shardy base) is approximately 7-10 $\mathrm{m}$ thick throughout the potential repository region and grades from partially welded and 12-15 percent porosity to nonwelded and 50-55 percent porosity. It represents a stratigraphic feature that may form a hydrologic-flow barrier. This unit was sampled in detail and discussed by Istok and others (1994) and Rautman and others (1995). The vitric, densely welded caprock unit of the Topopah Spring Tuff (vitric caprock) is very thin, approximately 0.2 to $0.4 \mathrm{~m}$ thick, and seems to be laterally extensive over the entire study area. The unit has a porosity of 1 to 4 percent and underlies a high-porosity ( $40-60$ percent) nonwelded tuff. It represents a lithologic discontinuity that may influence downward movement of water and result in lateral diversion. The rocks on the crest of Yucca Mountain belong to the upper-cliff unit of the Tiva Canyon Tuff, which changes in porosity from approximately 30 percent to 10 percent over a short vertical distance, so that erosion on the crest of the ridge has produced a slight north-south trend in porosity. Because this unit forms most of the exposed bedrock surface over the potential repository, it was important to characterize the material properties of this upper boundary on a north-south trend.

Sampling was performed using water and a hand-held, gas-powered drill with a $2.5-\mathrm{cm}$ I.D. core bit. Field samples ranged from 3 to $10 \mathrm{~cm}$ long. Samples were placed in plastic bags and labeled with a transect identification and a sample number. This number was either the distance along the transect or a consecutive position value. Relative vertical sample positions were measured using a 1.5-m Jacob's staff and Brunton compass, and they were adjusted to true stratigraphic positions. Relative horizontal positions were measured in the field using a Topofil string measuring device or $30.5-\mathrm{m}$ chain.

\section{Laboratory Measurements}

Cores were prepared for measurement in the laboratory by trimming the ends to a final core length of approximately $5 \mathrm{~cm}$. If less core was obtained, the final size was kept as long as possible. All cores were labeled with a permanent ink marker. Core samples 
Table 1. Transects and their location, northing and easting according to Nevada State Plane Coordinate System, length, number of samples, and lithologic description

[Vertical transects start at the listed location and extend downslope; horizontal transects start at the listed location and extend northward; m, meters]

\begin{tabular}{|c|c|c|c|c|c|c|}
\hline Transect ID & Location description & Northing & Eastlng & $\begin{array}{l}\text { Length } \\
\text { (m) }\end{array}$ & $\begin{array}{l}\text { Number } \\
\text { of } \\
\text { samples }\end{array}$ & Llthologle description \\
\hline $\begin{array}{l}\text { Solitario Canyon } \\
\text { (vertical) }\end{array}$ & $\begin{array}{l}\text { West side of crest, } \\
\text { below USW UZ-6s. }\end{array}$ & 231,650 & 170,140 & 315 & 169 & $\begin{array}{l}\text { Upper cliff zone of the Tiva Canyon } \\
\text { Tuff to the top of the lower litho- } \\
\text { physal zone of the Topopah Spring } \\
\text { Tuff. }\end{array}$ \\
\hline $\begin{array}{l}\text { Busted Butte } \\
\text { (vertical) }\end{array}$ & $\begin{array}{l}\text { Northeast side of } \\
\text { Busted Butte. }\end{array}$ & 225,920 & 174,650 & 135 & 102 & $\begin{array}{l}\text { Upper nonwelded tuff of the } \\
\text { Topopah Spring Tuff to the basal } \\
\text { vitrophyre. }\end{array}$ \\
\hline $\begin{array}{l}\text { Yucca Wash } \\
\text { (vertical) }\end{array}$ & $\begin{array}{l}\text { South side of } \\
\text { Yucca Wash. }\end{array}$ & 238,660 & 168,550 & 290 & 139 & $\begin{array}{l}\text { Caprock of the Tiva Canyon Tuff } \\
\text { through the Calico Hills } \\
\text { Formation. }\end{array}$ \\
\hline $\begin{array}{l}\text { Pagany Wash } \\
\text { (vertical) }\end{array}$ & $\begin{array}{l}\text { Upper Pagany Wash, } \\
\text { north-facing slope. }\end{array}$ & 236,220 & 170,700 & 25 & 20 & $\begin{array}{l}\text { Caprock of the Tiva Canyon Tuff to } \\
\text { the upper lithophysal zone. }\end{array}$ \\
\hline $\begin{array}{l}\text { Calico Hills } \\
\text { (vertical) }\end{array}$ & $\begin{array}{l}\text { Windy Wash, south- } \\
\text { facing slope. }\end{array}$ & 238,660 & 167,640 & 102 & 66 & $\begin{array}{l}\text { Calico Hills Formation and } \\
\text { Prow Pass Tuff. }\end{array}$ \\
\hline $\begin{array}{l}\text { Yucca Crest } \\
\text { (horizontal) }\end{array}$ & $\begin{array}{l}\text { Crest of Yucca } \\
\text { Mountain. }\end{array}$ & 229,510 & 170,230 & 5,030 & 45 & $\begin{array}{l}\text { Upper cliff zone of the } \\
\text { Tiva Canyon Tuff. }\end{array}$ \\
\hline $\begin{array}{l}\text { Shardy Base } \\
\text { (horizontal) }\end{array}$ & West side of crest. & 231,650 & 170,080 & 701 & 65 & $\begin{array}{l}\text { Nonwelded base of the } \\
\text { Tiva Canyon Tuff. }\end{array}$ \\
\hline $\begin{array}{l}\text { Topopah Caprock } \\
\text { (horizontal) }\end{array}$ & West side of crest. & 231,340 & 170,080 & 1,823 & 50 & $\begin{array}{l}\text { Vitric caprock of the } \\
\text { Topopah Spring Tuff. }\end{array}$ \\
\hline
\end{tabular}

were saturated with $\mathrm{CO}_{2}$ after evacuation of air under a vacuum to enable the saturation of small internal pores and then submersed in distilled, de-aired water and left overnight. Samples were removed, dried with a damp towel (American Society of Testing Materials, 1977), and weighed to determine saturated weight. The sample was then suspended in a beaker of water in a wire basket to determine volume displacement and then dried in a relative humidity oven at $60^{\circ} \mathrm{C}$ and 45 percent relative humidity and reweighed. Relative-humidity drying removes water from the pores but retains water in the crystal or mineral structure (Bush and Jenkins, 1970). Hydrologic-flow properties were measured before conventional oven drying $\left(105^{\circ} \mathrm{C}\right)$ because structural damage may occur in certain samples with delicate clay structures or zeolites. Finally the samples were dried at $105^{\circ} \mathrm{C}$ to obtain a standard dry weight.

A representative set of 41 samples was selected for additional measurements to form a composite vertical profile of all units. Imbibition tests were conducted on these samples to determine sorptivity at relativehumidity-dried saturations. Samples were weighed and placed on a wet towel saturated by using a Mariotte system with a constant head of zero. They were reweighed repeatedly, and times and weights were recorded in order to describe the quantity of water imbibed with time. When plotted as water imbibed versus the square root of time (t), early imbibition (I) is calculated as sorptivity $(\mathrm{S})$ according to $\mathrm{I}=\mathrm{St}^{0.5}$ (Philip, 1957; Talsma, 1969).

After the imbibition tests, the samples were resaturated, and saturated hydraulic conductivity was determined on the same 41 samples using a steadystate permeameter that forces water through the core at a measured pressure while weighing the outflow with time. All samples were then dried at $105^{\circ} \mathrm{C}$ for 48 hours for final calculations. Porosity [(saturated weight-dry weight)/volume], bulk density (dry weight/ volume), and particle density [porosity/(1-bulk density)] were calculated. Following these measurements, subsamples approximately $1 \mathrm{~cm}$ long were cut, and moisture-retention curves were determined for the subsamples using a chilled-mirror psychrometer (Model CX-2 Water Activity Meter, Decagon Devices, Inc., Pullman, Wash.) to determine water potential at various saturations. Each of the moisture-retention curves were fitted using (1) van Genuchten (1980) fitting $\alpha$ and $n$, while $m=n-1 / n$; (2) fitting $\alpha, n$, and $m$; and (3) Brooks and Corey (1964). For the van Genuchten fits, residual water content was estimated 
from the difference between relative-humidity ovendry weight and $105^{\circ} \mathrm{C}$ oven-dry weight.

\section{RESULTS}

\section{Physical Properties}

Trends in porosity and particle density are observed in each of the eight transects (figs. 3-10). The major flow units (Tiva Canyon and Topopah Spring Tuffs) are apparent in the Solitario Canyon transect (fig. 3), with high porosity zones at the top of each major flow unit and very high porosity zones in the nonwelded units of the Paintbrush Tuff (Ptn, Ortiz and others, 1985). Particle density follows similar trends in the welded units but is very low in the PTn. Samples from Busted Butte (fig. 4) show similar trends in properties in the Topopah Spring unit as those from Solitario Canyon, and porosity is very low, 2-3 percent, in the basal vitrophyre. The Yucca Wash vertical transect (fig. 5) extends from the top of the Tiva Canyon Tuff through the PTn, the Topopah Spring Tuff and the tuffaceous beds of Calico Hills Formation. There appears to be more scatter in the porosities of these cores, which is probably due to differences in welding. The Yucca Mountain and Pah Canyon Tuffs are present in the Yucca Wash transect, and the Yucca Mountain Tuff comprises a full suite of nonwelded to welded tuffs. Densely welded caprock of the Tiva Canyon Tuff occurs in this transect, and in the Pagany Wash transect (fig. 6). Low porosity values that increase rapidly with depth are recorded for samples from both of these transects. Most of the densely welded Tiva Canyon Tuff caprock has been eroded south of Drill Hole Wash (fig. 1), resulting in exposures of the more permeable lower caprock and upper-cliff zones. Zeolitized rock in the Calico Hills Formation (fig. 7) increase slightly in porosity with depth throughout the transect. Two samples of the Prow Pass Tuff of the Crater Flat Tuff are also present in the Calico Hills transect.

The horizontal transect on Yucca Crest was designed to investigate the properties of the upper cliff unit of the Tiva Canyon Tuff, which decreases in porosity with depth fairly rapidly (fig. 8). A regression analysis was performed on porosity with depth and showed a slight trend of decreasing porosity toward the south, where the surface of the mountain is eroded slightly more. The horizontal transect through the nonwelded shardy base of the Tiva Canyon Tuff (fig. 9), originally designed to investigate horizontal variability, actually identified vertical trends. Based on the data from the Solitario Canyon transect, the top of the unit is low in porosity (15 percent) and increases to about 55 percent porosity over a vertical distance of approximately $7 \mathrm{~m}$. Any deviation in elevation during sampling, such as moving downslope due to topographic changes along the horizontal transect, resulted in a change in porosity. Comparison of the data with the vertical transect at Solitario Canyon indicates that the interpretation of the changes was due to the vertical porosity trend, rather than lateral variation. These trends were investigated by Istok and others (1995) with a series of 26 vertical transects through the unit to produce a 2-dimensional representation of porosity and permeability that supported interpretations of influences of deterministic processes on hydrologic properties and the interpretation of a small degree of horizontal variability, while the vertical variability, though large, was predictable. The transect along the exposure of the vitric top of the caprock of the Topopah Spring Tuff (fig. 10) was planned following the measurements of physical and hydrologic properties on samples from the Solitario Canyon transect. The porous PTn under this extremely low porosity, very thin unit $(0.2-0.3 \mathrm{~m})$, has been overlooked or averaged into larger units in several modeling exercises (Wittwer and others, 1992; Brown and others, 1994). The sampling of this unit exhibits some of the same problems associated with the sampling of the shardy base unit, that of rapid vertical change in porosity. There are several locations along this transect where the porosity exceeds 6 percent. These locations most likely indicate a deviation downslope from the upper contact of the unit rather than lateral variation.

All individual measurements for each core sample are listed in Appendix I, with all samples listed for each transect along with transect distance, physical properties, and hydrologic-flow properties. Not all measurements were obtained from all samples.

Descriptive statistics were calculated for porosity, bulk density, particle density, saturated hydraulic conductivity, and sorptivity for each unit sampled for all transects combined (table 2). The principal differences between units are due to the variation in welding, which most directly influences porosity. Another characteristic influencing porosity is secondary alteration. Mean porosity varies from 3 percent in the vitric caprock and basal vitrophyre of the Topopah Spring Tuff to as high as 52 percent in the bedded and pumicefall tuffs. The variation in bulk density shows the inverse trend. Particle density varies from $2.56 \mathrm{~g} / \mathrm{cm}^{3}$ in the densely welded caprock of the Tiva Canyon Tuff to $2.31 \mathrm{~g} / \mathrm{cm}^{3}$ in the zeolitized part of the Calico Hills Formation. Particle density generally is fairly uniform for all the welded units and for the rocks that have somewhat lower densities in the nonwelded units. 
Solitario Canyon Transect

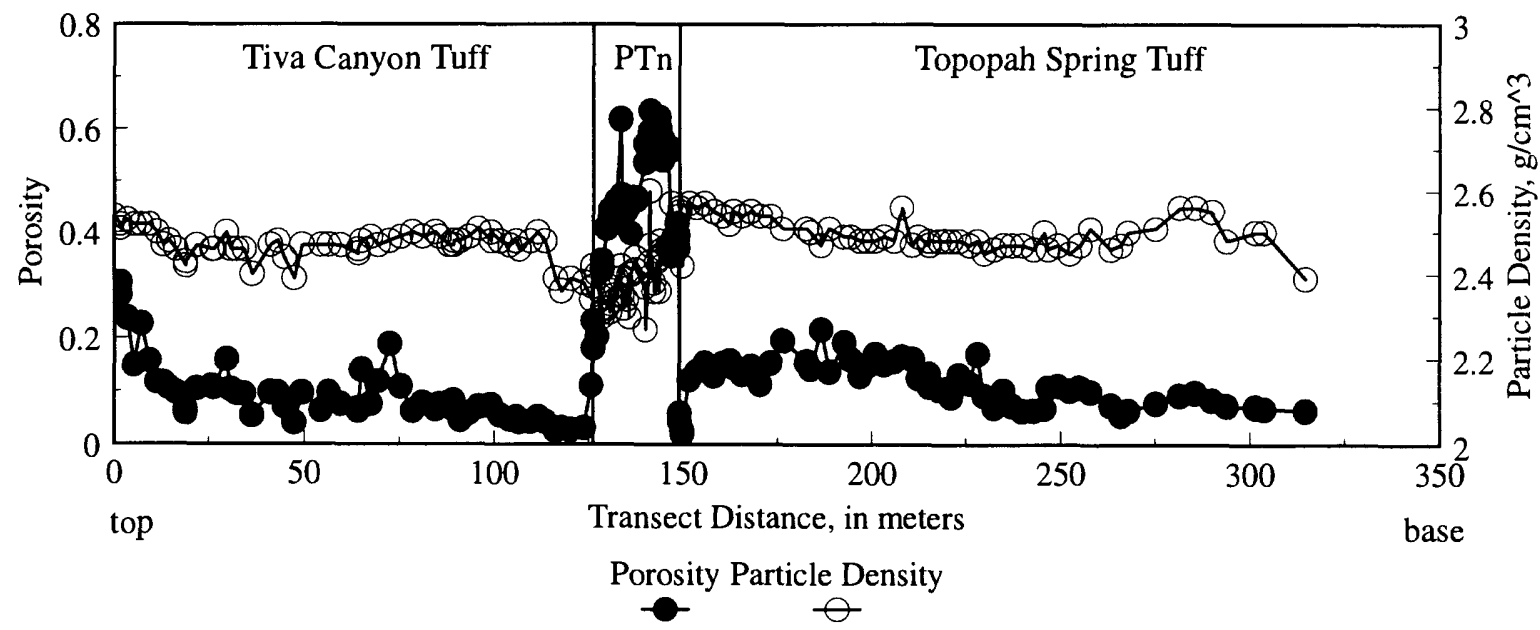

Figure 3. Porosity and particle density for core samples from Solitario Canyon vertical transect.

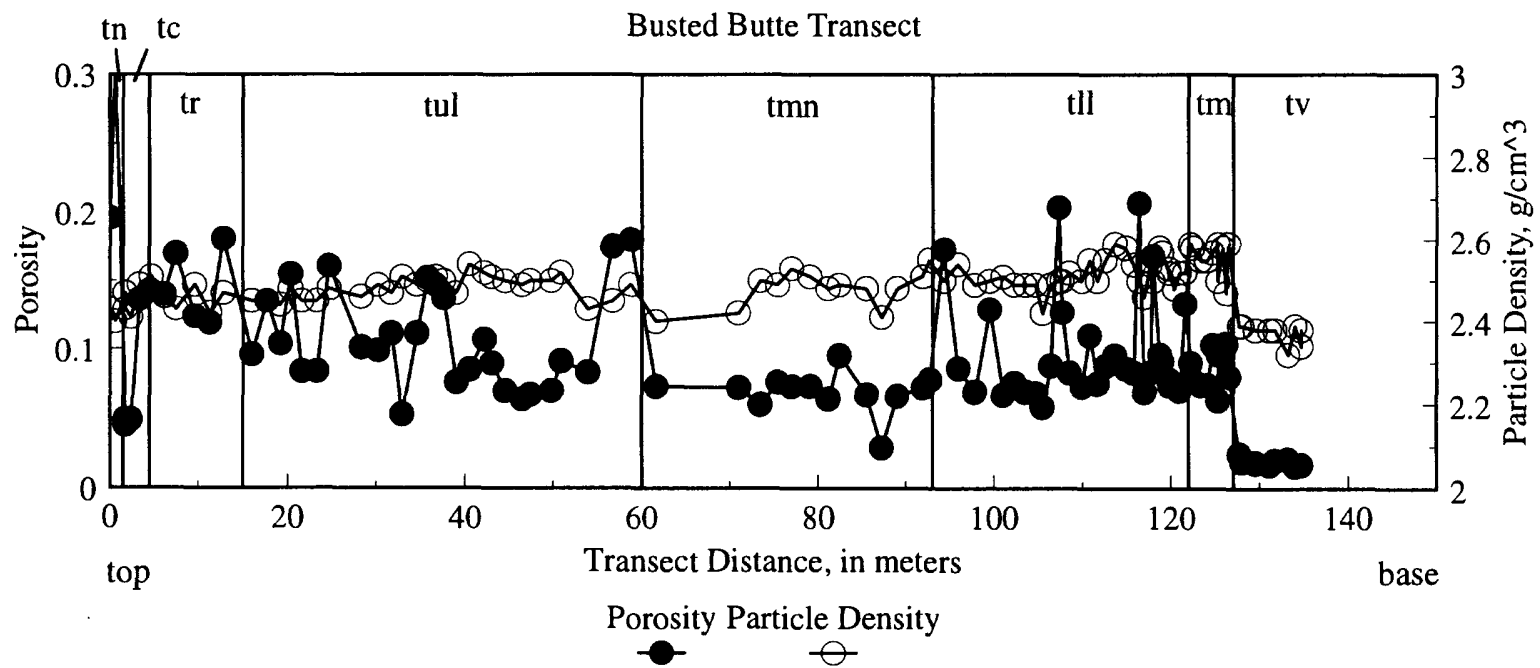

Figure 4. Porosity and particle density for core samples from Busted Butte vertical transect.

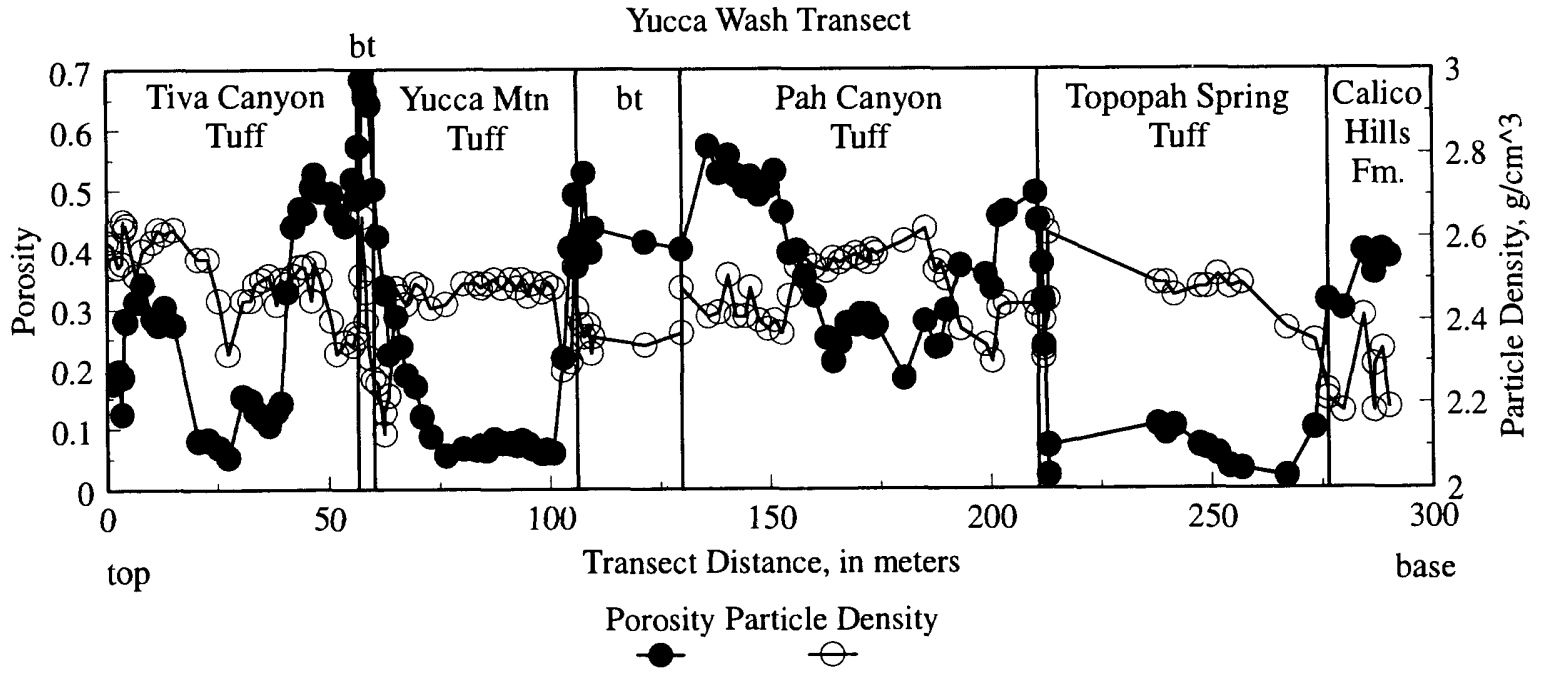

Figure 5. Porosity and particle density for core samples from Yucca Wash vertical transect. 
Pagany Wash Transect

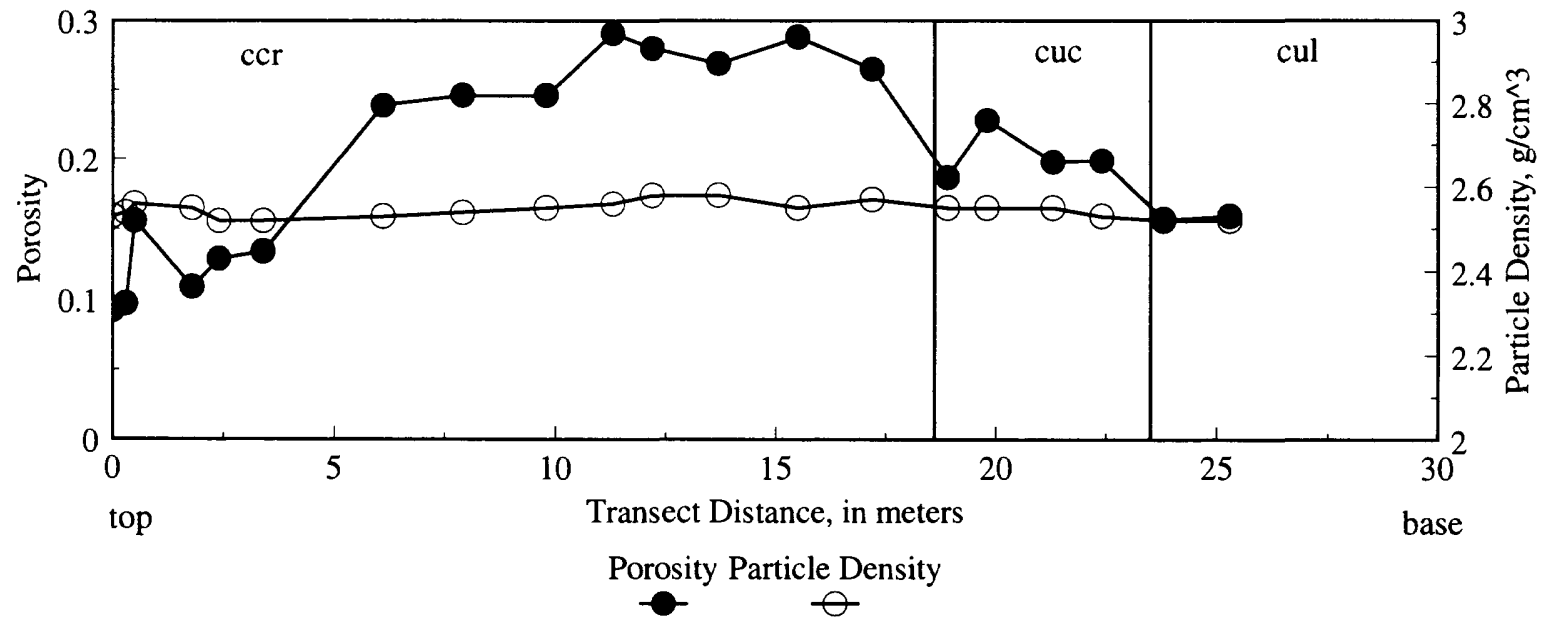

Figure 6. Porosity and particle density for core samples from Pagany Wash vertical transect.

Calico Hills Transect

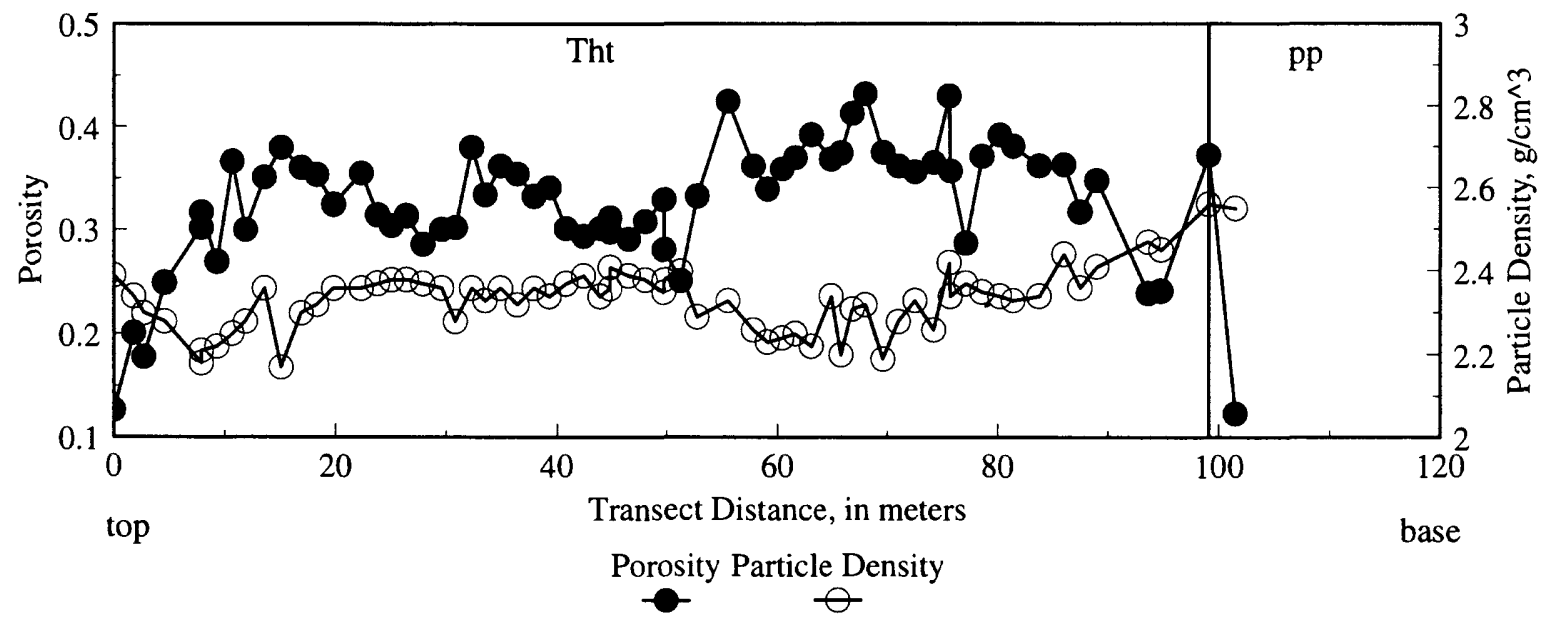

Figure 7. Porosity and particle density for core samples from Calico Hills Formation vertical transect.

Yucca Crest Transect

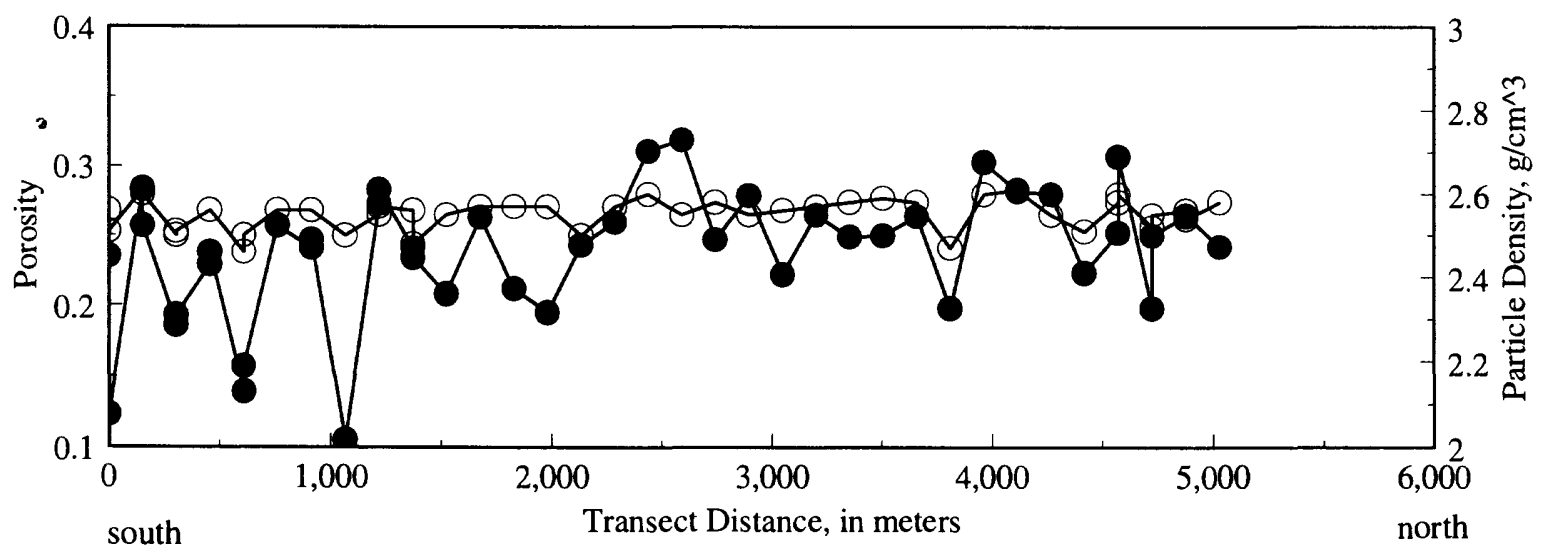

Porosity Particle Density

$\rightarrow-\theta$

Figure 8. Porosity and particle density for core samples from Yucca Crest horizontal transect. 
Shardy Base Transect

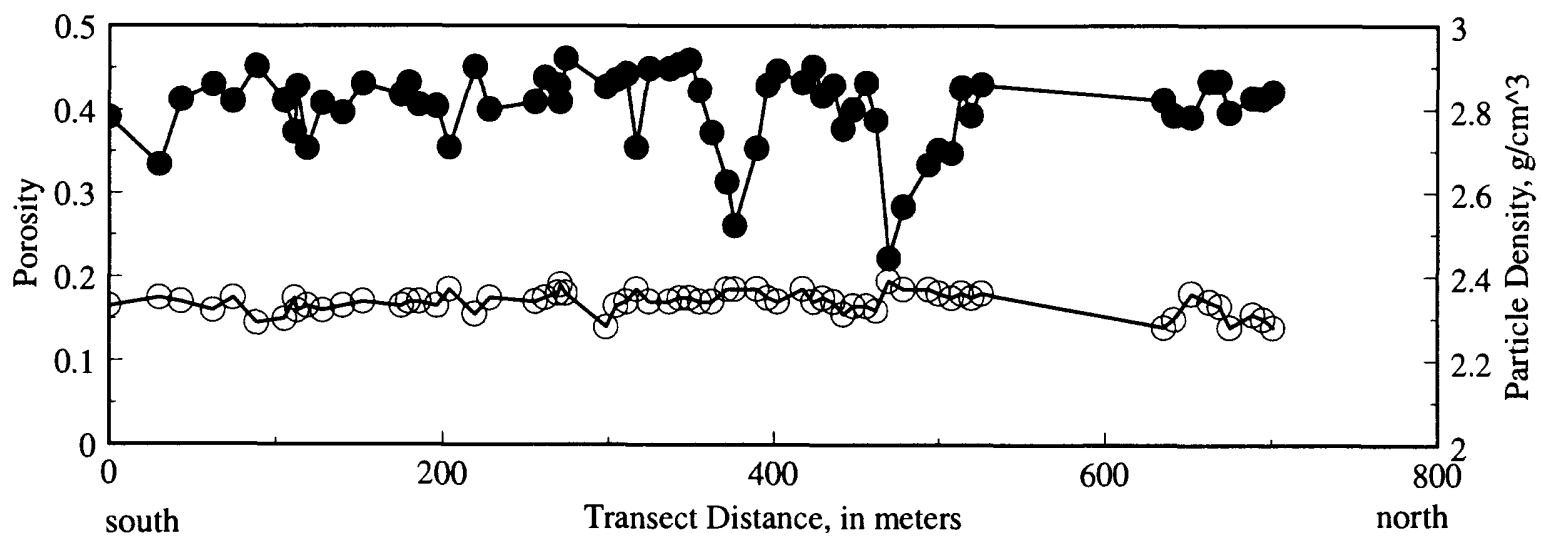

Porosity Particle Density

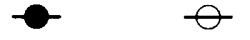

Figure 9. Porosity and particle density for core samples from shardy base horizontal transect.

Topopah Spring Caprock Transect

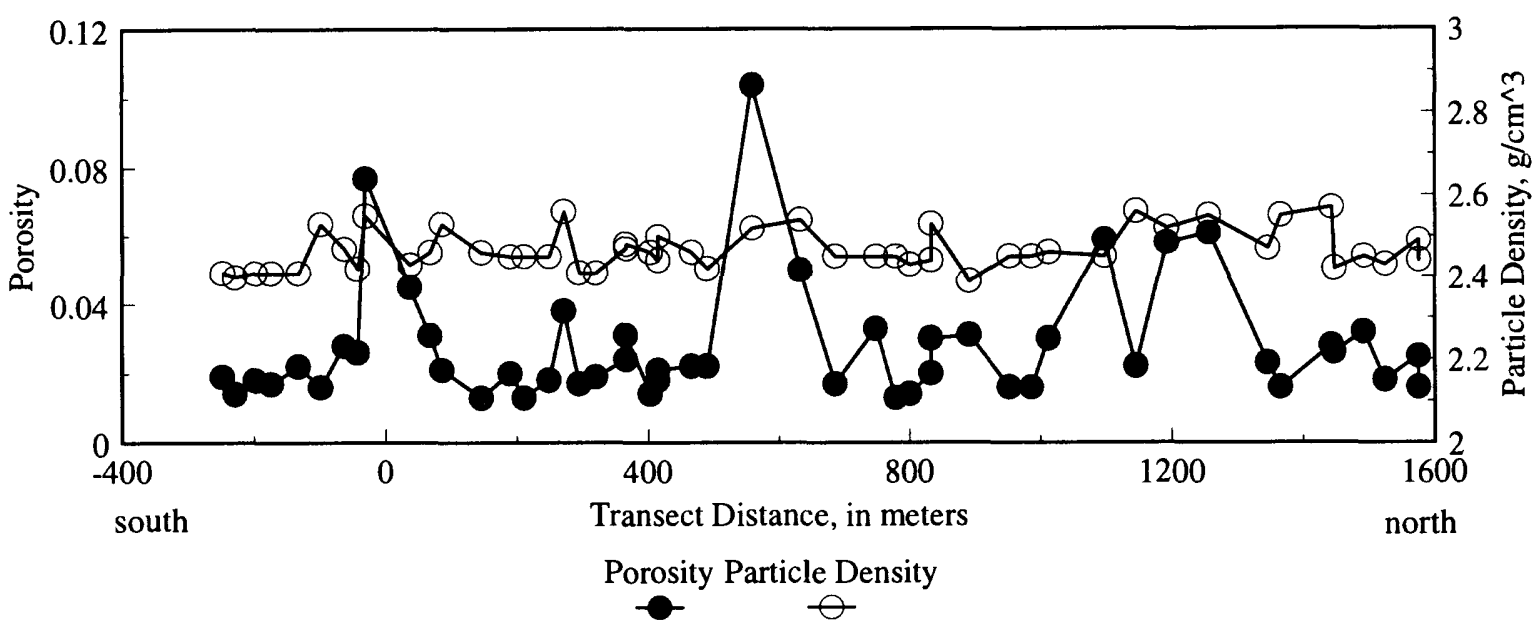

Figure 10. Porosity and particle density for core samples from Topopah Spring Tuff caprock horizontal transect. 


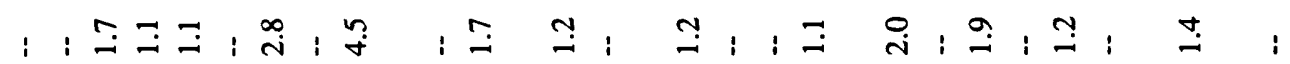

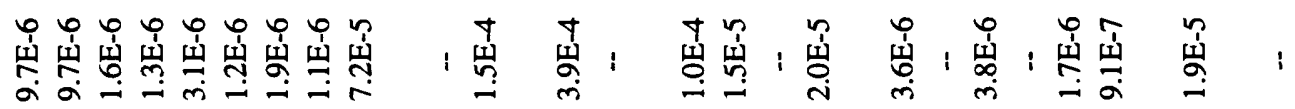

กำmm-n-

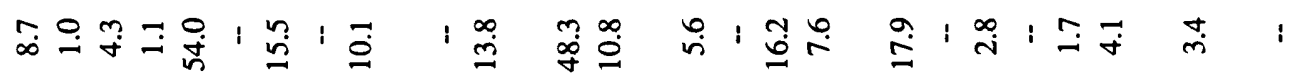

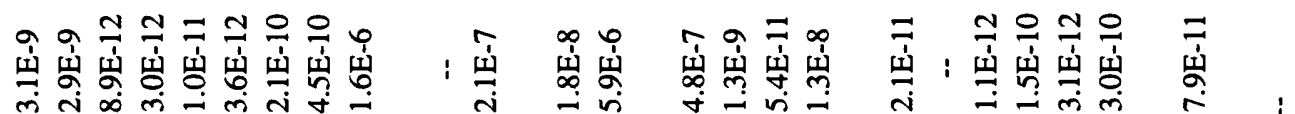

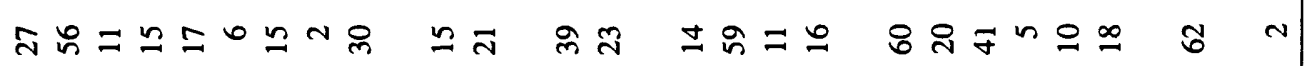

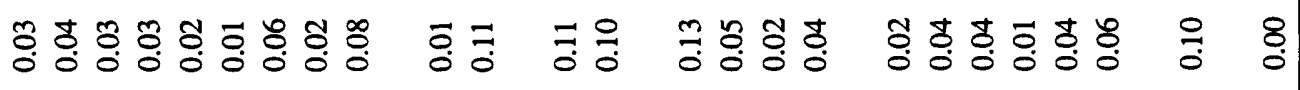

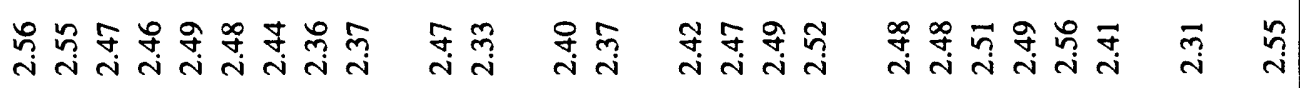

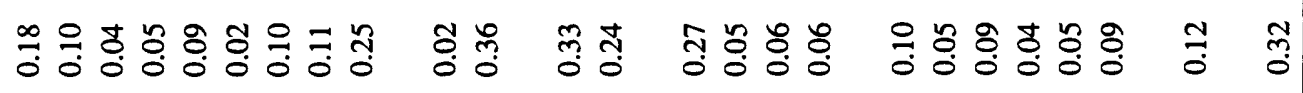

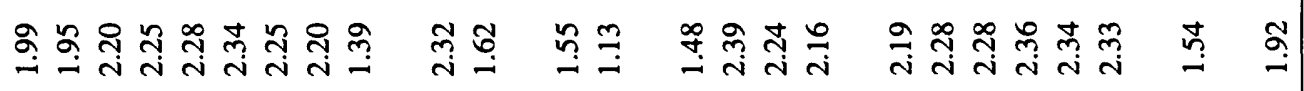

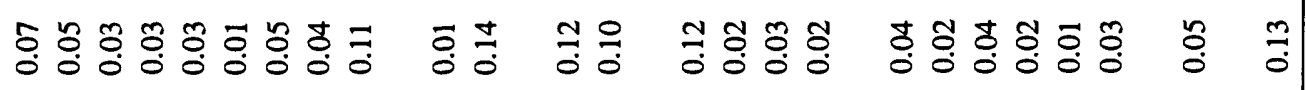

청 궁 


\section{Hydrologic-Flow Properties}

Saturated hydraulic conductivity (also referred to as conductivity) was not determined on very lowporosity samples with conductivities below $1 \mathrm{E}-12 \mathrm{~m} / \mathrm{s}$ due to equipment limitations. This biases the calculation of mean conductivity when it is compared to other properties that were measured on many more samples. Conductivity ranged from $5.9 \mathrm{E}-6 \mathrm{~m} / \mathrm{s}$ for bedded tuffs to $3.0 \mathrm{E}-12 \mathrm{~m} / \mathrm{s}$ for the clinkstone unit of the Tiva Canyon Tuff.

Conductivity appears to be well correlated with the physical properties. Porosity of most of the tuffs may be of a similar nature, that is, pore structure and tortuosity. Some of the tuffs have alterations to the porosity, such as zeolites, which form in the flow channels of the highly porous Calico Hills Formation and reduce conductivity. Another difference is in vitric caprock and vitrophyre samples (vitrophyre), many of which have microfractures that contribute to saturated flow but do not represent a large enough volume to affect porosity. The relationship between measurements of conductivity and porosity is improved when porosity is calculated using relative-humidity-dried weights compared to when $105^{\circ} \mathrm{C}$ dry weights are used. This observation is attributed to the presence of clay minerals in some samples. These clays contain loosely bound structural water that is not available for flow. When dried in a high relative-humidity environment, water is removed from the flow channels but maintained in the minerals, thus allowing for more relevant flow-channel porosity determinations.

Nonlinear regression analyses were performed on porosity and conductivity values measured on sam- ples from the Solitario Canyon transect and for samples from the Yucca Wash transect (table 3). A scatterplot of conductivity and porosity for the Solitario Canyon transect (fig. 11a) illustrates the separate grouping of the vitrophyre samples (vitric caprock of the Topopah Spring Tuff and vitrophyre of the Tiva Canyon Tuff). The regressions were done on lithologic groupings of samples in order to increase the predictive capability. Coefficients of determination $\left(\mathrm{r}^{2}\right)$ are high for the Solitario Canyon transect with $\mathrm{r}^{2}=0.72$ for the vitric samples and $\mathrm{r}^{2}=0.90$ for all remaining welded and nonwelded samples.

The Yucca Wash transect has a larger scatter of points due to the inclusion of the samples from the Calico Hills Formation and several samples of the Pah Canyon Tuff. The samples from the Calico Hills Formation contain large amounts of zeolites, but the Pah Canyon Tuff samples also appear to have high amounts of clay. This is suggested by the large difference in these samples between porosities calculated from relative humidity dry weights, which retains the water in clays, and $105^{\circ} \mathrm{C}$ oven-dry weights, which removes the water from the clays. These samples have high porosities, but the development of zeolites and clays within the pore channels restricts flow, thus changing the relationship between porosity and saturated hydraulic conductivity. The vitrophyre and vitric caprock samples, on the other hand, have higher conductivities than would be suggested by their very low porosities. These vitrophyre samples have a bimodal pore-size distribution (discussed in following section) with very low matrix porosity due to the vitrification but have small microfractures that transmit water yet contribute little

Table 3. Nonlinear regression analysis performed for porosity and saturated hydraulic conductivity for the Solitario Canyon transect and the Yucca Wash transect

[N, number of samples; $r^{2}$, coefficient of determination; $K_{s}$, saturated hydraulic conductivity; $\phi$, porosity, calculated from relative-humidity drying]

\begin{tabular}{llrr}
\hline \multicolumn{1}{c}{ Transect N lithology } & \multicolumn{1}{c}{ Regression equation } & \multicolumn{2}{c}{${ }^{2}$} \\
\hline Solitario Canyon transect & & & \\
$\quad$ Welded and nonwelded & $\mathrm{K}_{\mathrm{s}}=-13.9+33.1 \phi-30.8 \phi^{2}$ & 0.90 & 36 \\
$\quad$ Vitric & $\mathrm{K}_{\mathrm{s}}=-7.4-56.6 \phi+417.6 \phi^{2}$ & 0.72 & 6 \\
Yucca Wash transect & & & \\
Welded and nonwelded & $\mathrm{K}_{\mathrm{s}}=0.00009-0.0007 \phi+0.0012 \phi^{2}$ & 0.39 & 100 \\
Welded and nonwelded, no clays & $\mathrm{K}_{\mathrm{s}}=-11.9+18.1 \phi-10.7 \phi^{2}$ & 0.77 & 88 \\
Clay (Pah Canyon Tuff and Calico Hills Formation) & $\mathrm{K}_{\mathrm{s}}=-8.8-13.1 \phi+32.1 \phi^{2}$ & 0.50 & 12 \\
Calico Hills Formation & $\mathrm{K}_{\mathrm{s}}=11.6-168.0 \phi+318.7 \phi^{2}$ & 0.84 & 6 \\
Vitric & $\mathrm{K}_{\mathrm{s}}=-9.1-40.8 \phi+506.9 \phi^{2}$ & 0.28 & 7 \\
\hline
\end{tabular}


(a)

Solitario Canyon Transect

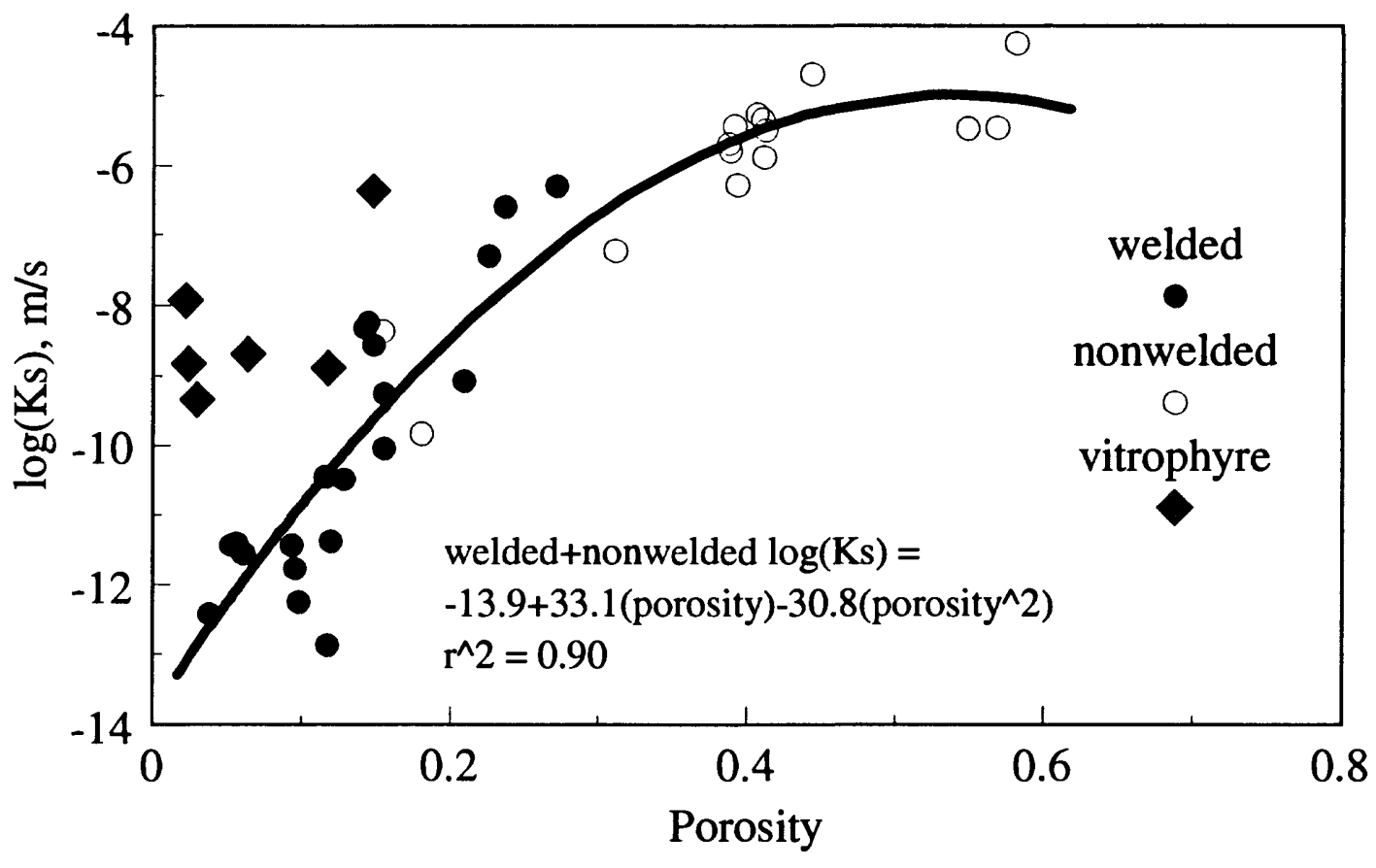

(b)

Yucca Wash Transect

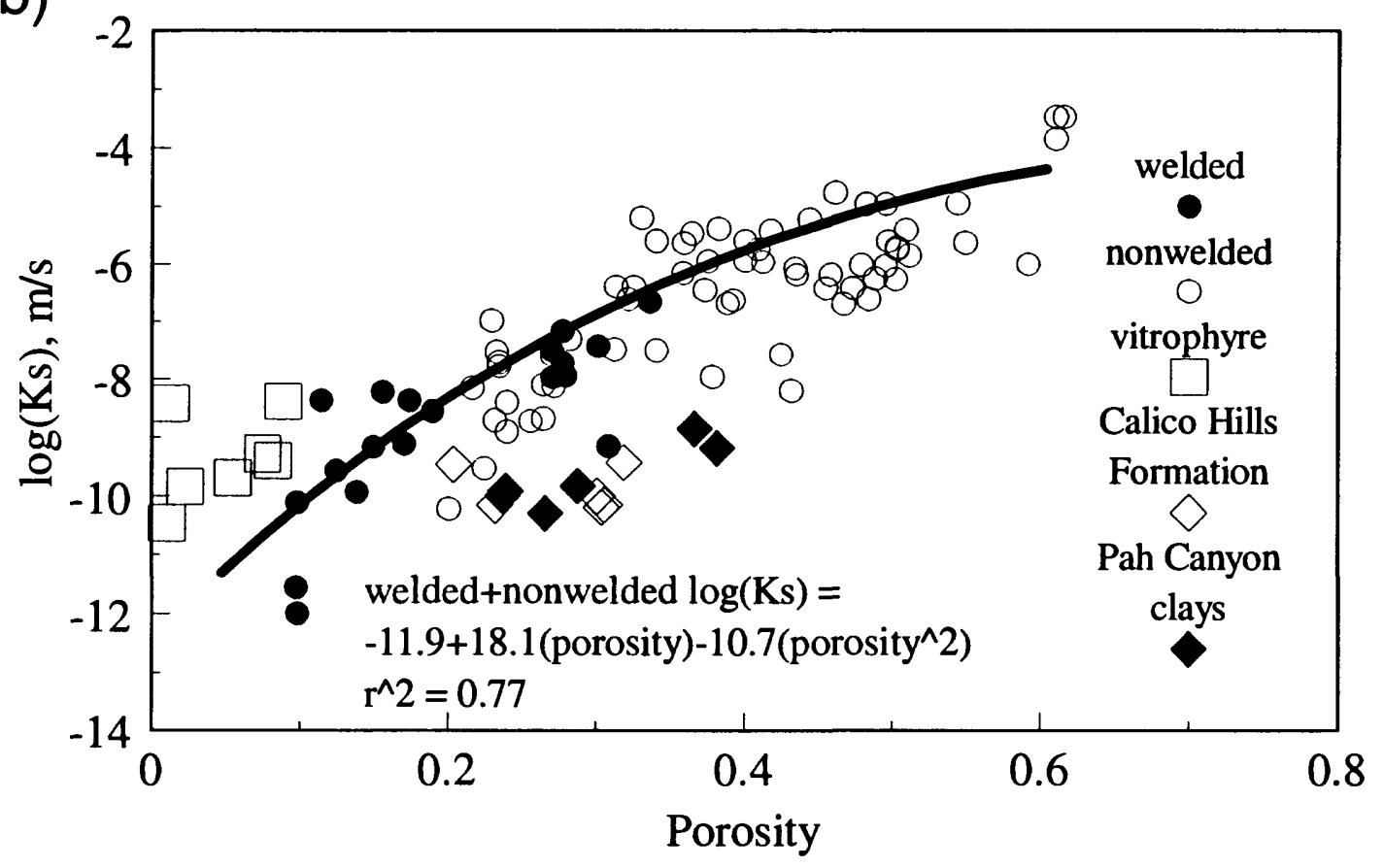

Figure 11. Relationship of porosity and saturated hydraulic conductivity for samples from (a) Solitario Canyon transect, and (b) Yucca Wash transect. Regression lines are for analyses on welded plus nonwelded samples only. 
to the porosity. Consequently, regression analyses were performed for several groupings of samples (fig. 1lb). The samples from the Calico Hills Formation are analyzed separately (Calico Hills) and also along with the clayey samples from the Pah Canyon Tuff discussed above (Pah Canyon Tuff). The vitrophyre and vitric caprock samples are analyzed separately (vitrophyre). The remaining nonwelded samples combined with all the welded samples comprised the last regression analysis. For ease of presentation, only regression lines and equations for the welded plus nonwelded samples (not including those with high amounts of clays) are included on figures $11 \mathrm{a}$ and $b$, but all equations and $r^{2}$ values are listed in table 3 . There are some differences between the regression equations developed using samples from the two transects. These differences may represent influences of lateral spatial variability on the relationship between porosity and conductivity. The differences more likely are due to the much thicker PTn present to the north in the Yucca Wash transect and the larger range in porosity, as well as the inclusion of the samples of the welded parts of the Pah Canyon and Yucca Mountain Tuffs. For these two transects, the most significant relationships between conductivity and porosity occur in the welded and nonwelded samples, not including samples with clays or vitric samples.

Sorptivity was determined for many fewer samples than conductivity and has a narrower range in values between units. The trends are similar for both measurements though with lower sorptivity in the welded units and the highest values in the nonwelded units.

\section{Estimates of Hydrologic Units for Flow Modeling}

Many of the lithologic units reflect predictable hydrologic and physical properties; however, some of these properties are not bounded by lithostratigraphic contacts. This is noticeably true in the upper Tiva Canyon Tuff where the caprock unit grades downward from densely welded to moderately welded tuff and is underlain by the upper cliff zone that is moderately welded tuff at the top and changes rapidly with depth to densely welded tuff. The references to welding in this paper are loosely characterized, however, and primarily infer a relationship with rock density. More current thought suggests that many of the rocks initially characterized as moderately welded are actually welded to densely welded but have a reduced density due to secondary alteration of the pores (C.A. Rautman, Sandia National Laboratory, personal commun., 1994). This example prompts the use of welding character rather than lithologic description and contacts to define hydrogeologic units with similar hydrologic properties and a reduction in variation within the unit.

To compile a complete set of data to accurately represent the means of each unit present in the unsaturated zone (table 4), the saturated hydraulic-conductivity data were extended to include estimates of conductivity for those samples upon which measurements could not be taken because of extremely low flow rates. Estimates of conductivity were made for densely welded samples using the regression for welded plus nonwelded samples from figure 11 a for the Solitario Canyon transect. This should more accurately reflect properties of the potential repository block than the Yucca Wash transect regressions. These estimates are included with measured data in calculations of mean and standard deviation for each hydrogeologic unit. The stratified nature of each of the major flow units is maintained, and the Tiva Canyon Tuff is divided into densely welded caprock, moderately welded units, and welded units. All nonwelded tuffs from the Paintbrush Group are in one unit, and the calculations of the Topopah Spring Tuff include welded rocks with and without incorporating highly vitric samples. The Calico Hills Formation samples and Prow Pass Tuff samples are maintained separately because of the lack of data for samples from the Prow Pass unit, and therefore, no evidence supports combining the units.

This approach reduces the standard deviation of property values within hydrogeologic units and more accurately represents the changes with depth that occur. The surface of Yucca Mountain is variably covered by the three Tiva Canyon units due to weathering and erosion (Flint and Flint, 1994). This is significant in the construction of hydrologic models because the surface unit will control the upper boundary conditions for infiltration at all locations. The weak point in this approach is in combining the nonwelded units of the Paintbrush Group that vary laterally in thickness, as well as including very thin layers that may or may not be laterally extensive. The rapid changes in physical properties with depth that occur, especially in the nonwelded base of the Tiva Canyon Tuff, as well as the intervening bedded and ash-fall tuffs, need to be described for each location to adequately describe the hydrologic character for a flow model. An additional problem with this approach is the exclusion of the more welded Yucca Mountain Tuff that is located north of the potential repository location. This welded unit appears to be absent within the potential repository block itself, which could reduce the impact of this omission and probably only restrict the user to smaller 


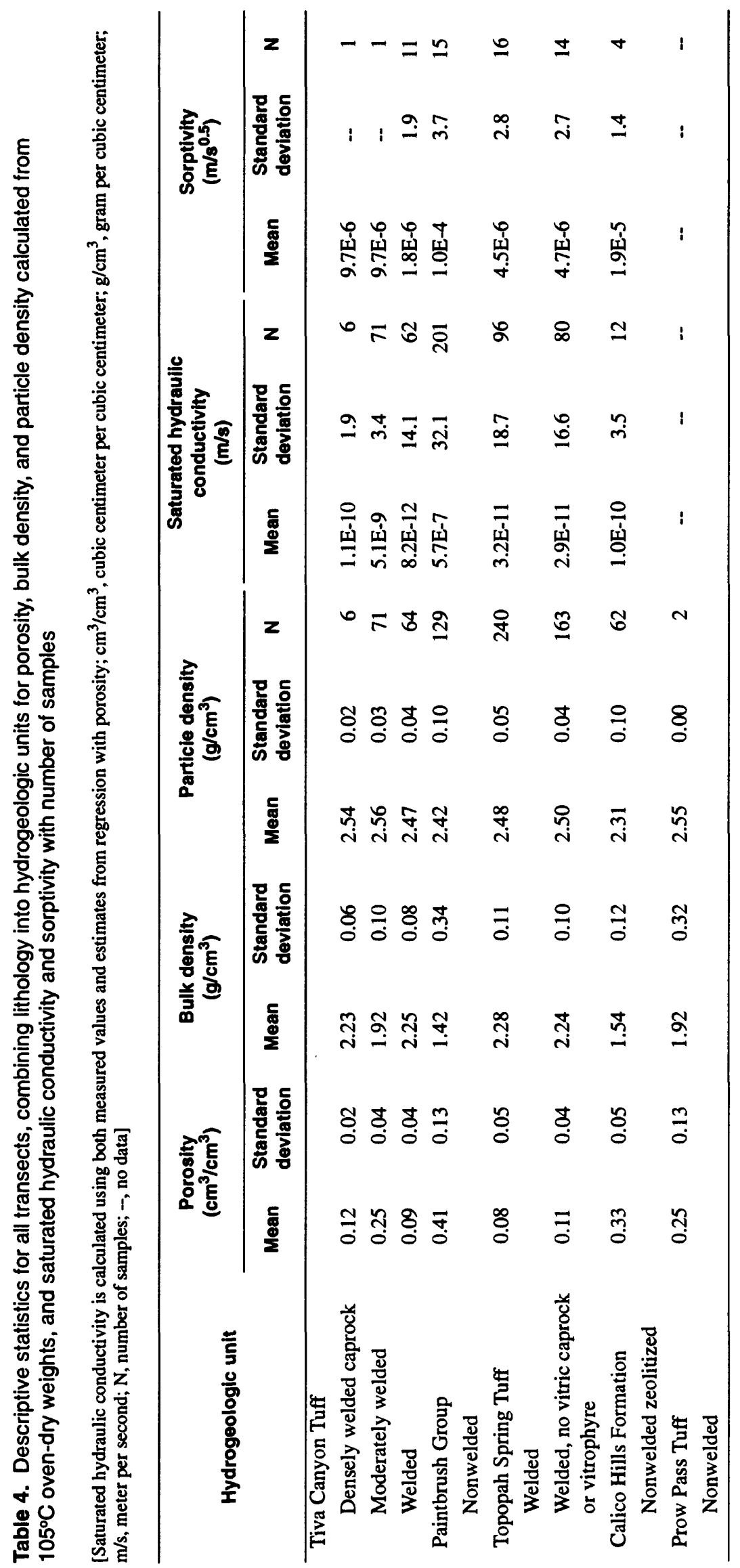


scale hydrologic modeling. Alternatively, this unit may be very important in light of flux estimates made by Flint and Flint (1994), suggesting that the tuffs in the northern portions of the site have much higher surface fluxes than those over the repository block due to downcutting of the washes, which exposes the higher porosity PTn at the surface. As high flux boundary conditions correspond to surface exposures of the PTn, a detailed geometry of the site and the inclusion of welded tuffs within the thick PTn to the north are critical information when flow models are being developed. In any case, this set of calculations provides a substantial improvement over the data sets used in simplified models that have predominated in the past (Nitao and others, 1992; Montazer and Wilson, 1984) and primarily adds the distinction of the variably welded Tiva Canyon Tuff, which is exposed at varying elevations in the flow unit over the surface of the site.

\section{Moisture Retention}

The results of the moisture-retention characterization are tabulated in table 5, with bulk density and porosity for the subsample (denoted as the sample ID from the original core plus an "s"). Included are residual water-content estimates from the original sample that were used in the van Genuchten parameter modeling. The moisture-retention data are tabulated in Appendix II and are plotted with the three models fit to the data for each of the 41 core samples in

Appendix III.

The two van Genuchten models generally fit the data very well. The three-parameter (estimated $m$ ) estimation model was not very different from the twoparameter (calculated $m$ ) model but in some cases fit the air-entry section of the data slightly better. The Brooks and Corey model fit many of the curves very well, but when it did not match, it generally underpredicted the wet end of the curve relative to the van Genuchten models. In general, the van Genuchten alpha parameter (approximately equal to the reciprocal of the air-entry pressure) increased as the porosity decreased, with the result that the welded samples have higher alpha values. This tendency was not observed for samples of Topopah Spring Tuff vitric caprock (BT1s and BT2s), which tended to lose water from the microfractures as the core dried and resulted in a higher alpha parameter. The data for BT1s may indicate a possible double-peak curve, which might describe a separate curve for fractures and matrix. Alternatively, the Tiva Canyon Tuff vitrophyre samples had extremely low alpha values and very high air-entry pressures. The resolution of the chilled-mirror psy- chrometer is plus or minus $0.13 \mathrm{MPa}$, however, and the description of air entry using the data may be slightly in error. The types of rocks in which the three models differed the most are the very low-porosity welded samples and the high-porosity samples with many larger pores that resulted in plots with a very flat slope at the wet end of the curve.

Relationships of porosity versus van Genuchten parameters were examined as a possible surrogate to intensive laboratory measurements (figs. 12a and b), and simple linear regressions were developed (table 6) for predictive purposes. For predictive purposes and considering the variability of $\boldsymbol{n}$ for all samples, porosity is fairly well related to $n$ for nonwelded samples $\left(r^{2}=0.44\right)$, while the welded samples have a narrow range of porosity and a larger range for $\alpha$ and $n$ that reduces predictive capabilities. This interpretation is also made in light of the study done by Glass and others (1994) that used regressions of porosity and van Genuchten parameters to predict parameters for modeling flow through a slab of Topopah Spring Tuff that had many measurements of porosity. Their relationships between porosity and van Genuchten parameters did not appear to be very good (no $r^{2}$ value was included in the paper) yet moisture-retention curves generated from the best and worst case predictions were very similar. The Calico Hills Formation zeolitized samples also have a narrow range of porosity; but whereas $\alpha$ has a large range, $n$ is clustered around 1.2, so despite the high $\mathrm{r}^{2}$ value $(0.98)$, the predictive value is low. While the relationship of porosity to permeability shown in figures $11 \mathrm{a}$ and $\mathrm{b}$ shows similarity for all the vitrophyre samples (includes both vitric caprock and vitrophyre), the data for the $\alpha$ parameter suggest some differences. All vitrophyre samples have very low porosity but air entry (approximately $1 /$ van Genuchten $\alpha$, and equal to Brooks and Corey $\alpha$ ) is low for the two Topopah Spring Tuff vitric caprock samples, whereas it is high for the Tiva Canyon and Topopah Spring Tuff vitrophyre samples. This indicates that the size of the microfractures may be larger for the caprock samples. The similarity of saturated hydraulic conductivities for these samples, however, suggests that the microfractures in the vitrophyre samples, while having an air- entry value near zero, will fill with water under a positive head, as done during a permeability measurement (or, for that matter, under a perched water body, in tuffs exposed at the surface, or during fracture flow) and contribute to higher flow rates. This may also suggest that the high permeability of these samples is due more to a lack of tortuosity of the microfractures rather than the larger size relative to pores. An implication of the difference in air entry and the similarity in saturated 


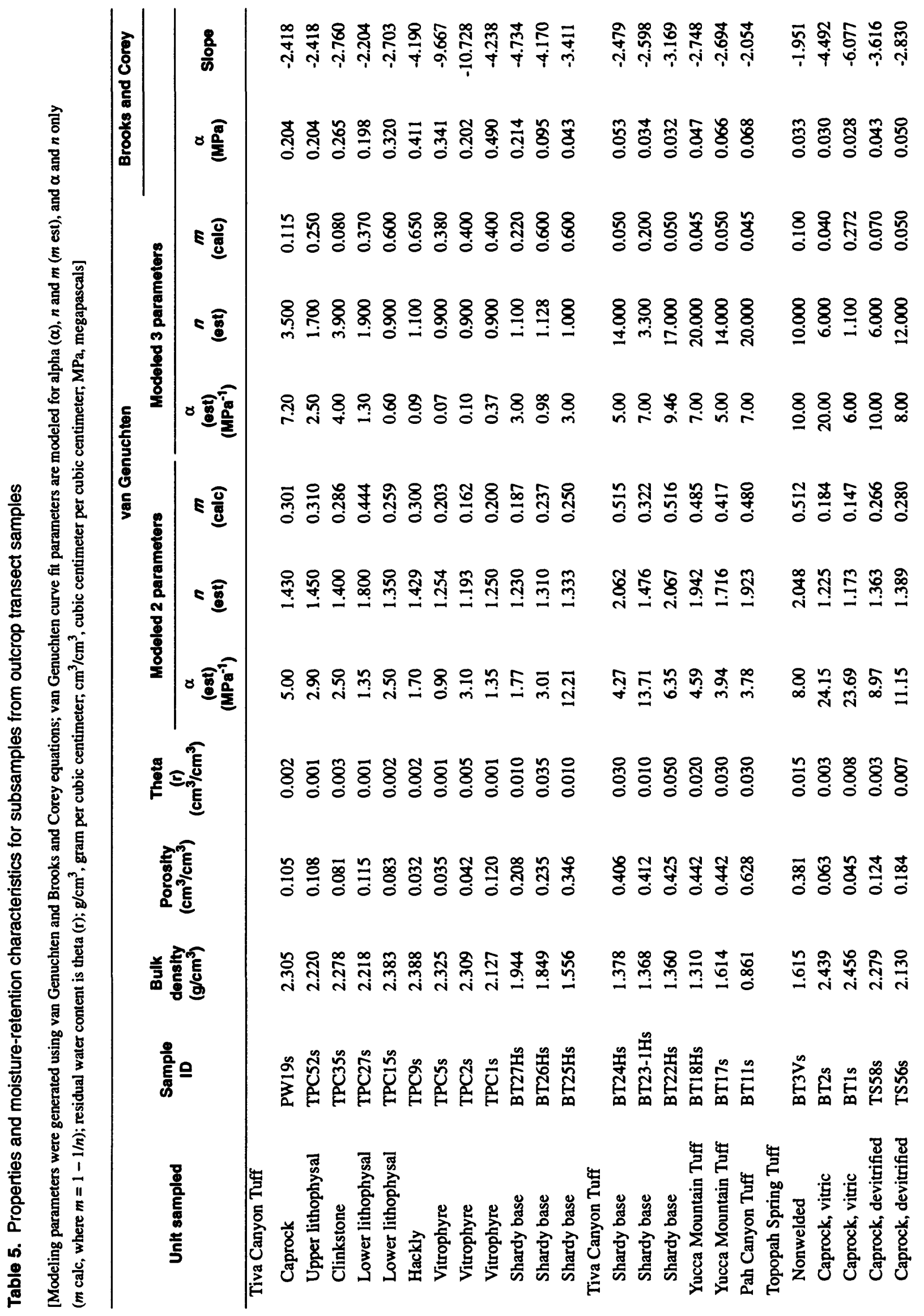




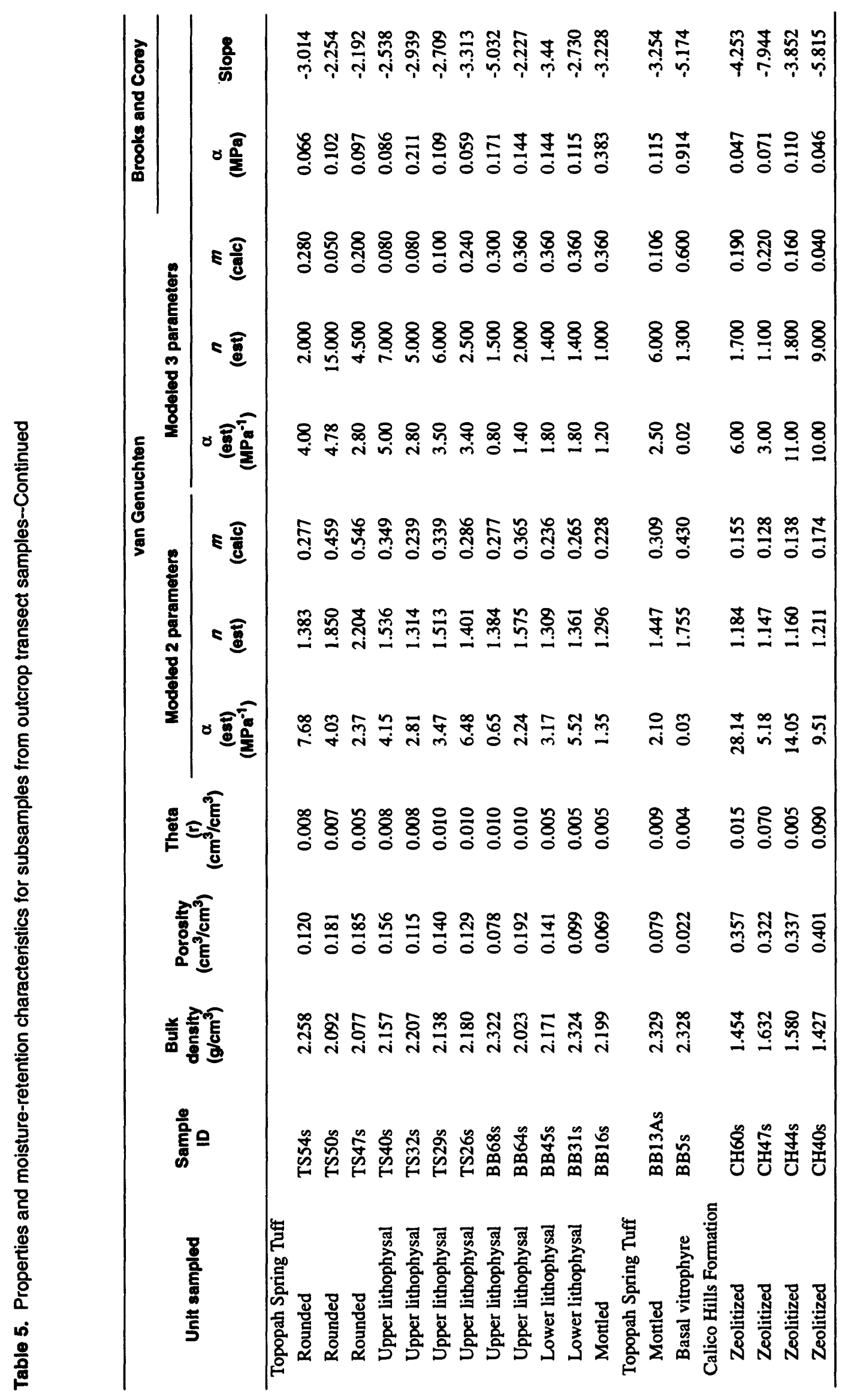


(a)

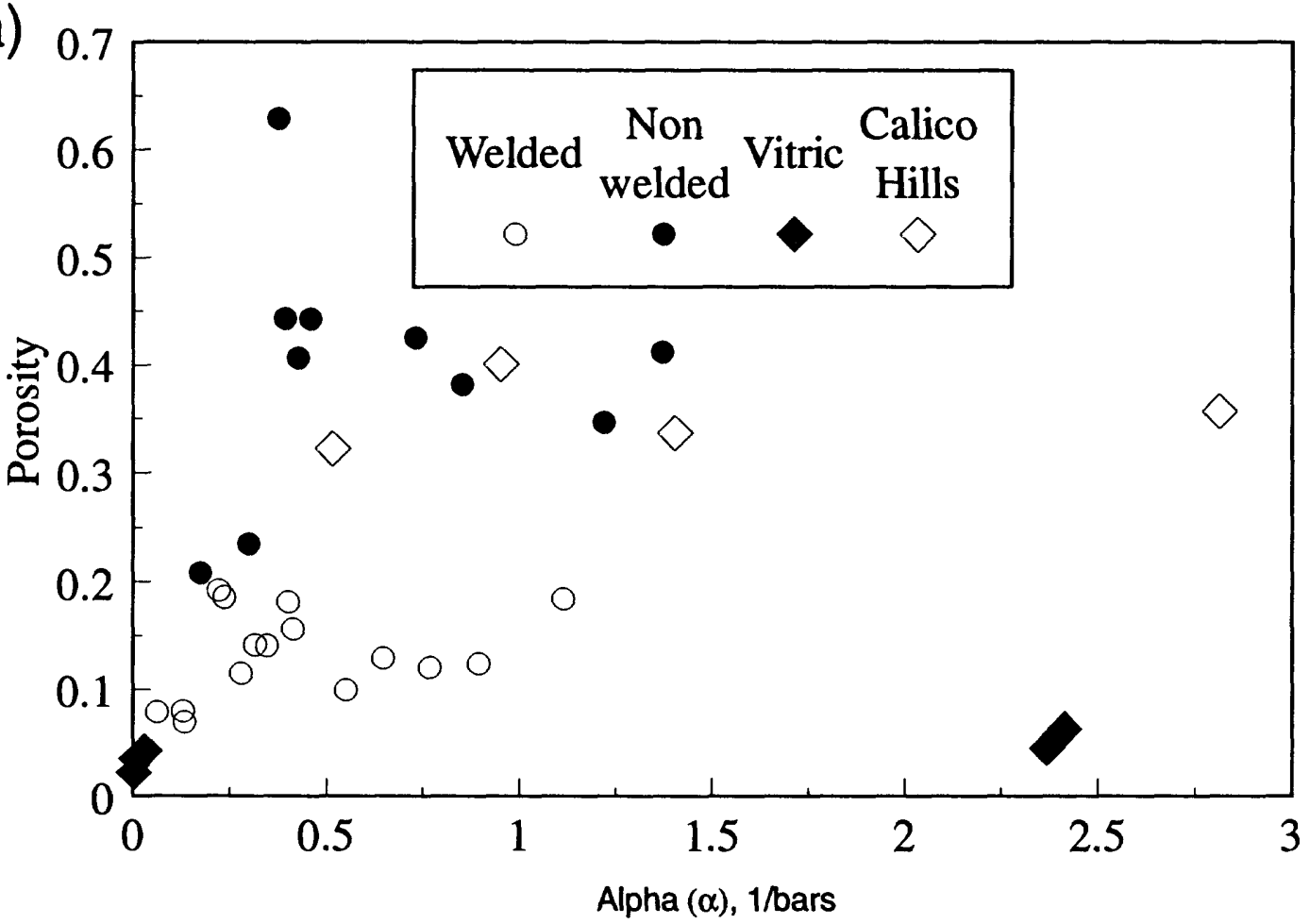

(b)

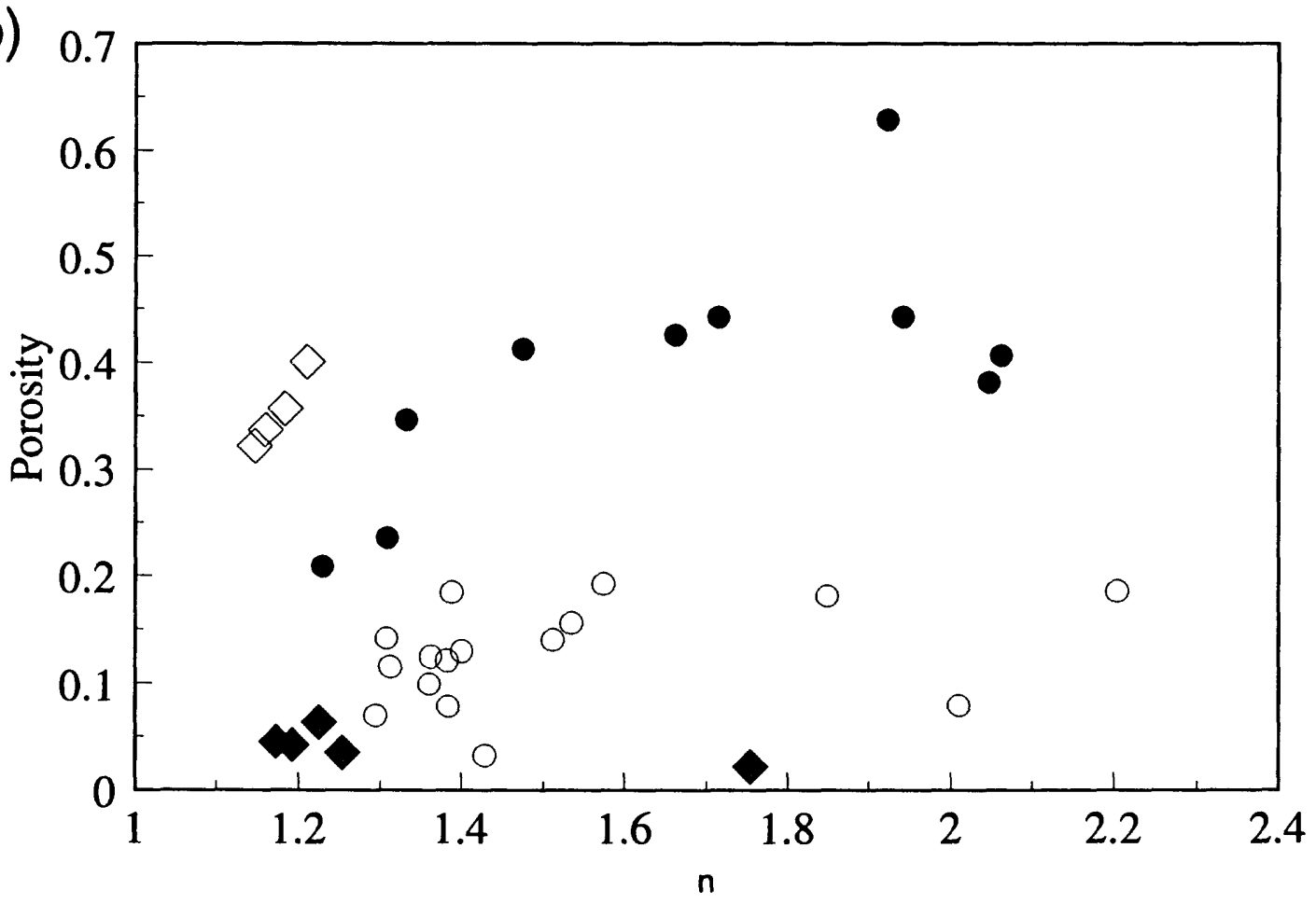

Figure 12. Relationship of porosity and van Genuchten parameters for (a) Alpha ( $\alpha$ ), and (b) $n$, for subsamples from 41 transect samples. 
hydraulic conductivity may be that in 1-dimensional modeling of flow through these units, water is more likely to enter the vitric caprock under unsaturated conditions, whereas higher saturations may be necessary for flow to occur through the Tiva Canyon and Topopah Spring Tuff vitrophyres.

Table 6. Linear regressions of van Genuchten $\alpha$ and $n$ parameters versus porosity for welded, nonwelded, vitrophyre, and Calico Hills Formation samples

$\left[r^{2}\right.$, coefficient of determination; $N$, number of samples; $\phi$, porosity]

\begin{tabular}{lccc}
\hline \multicolumn{1}{c}{ Sample } & Regression equation & $\mathrm{r}^{2}$ & $\mathrm{~N}$ \\
\hline Welded & $\alpha=0.032+2.87(\phi)$ & 0.20 & 20 \\
& $n=1.17+2.66(\phi)$ & 0.20 & 20 \\
Nonwelded & $\alpha=0.49+0.31(\phi)$ & 0.01 & 10 \\
& $n=0.95+1.94(\phi)$ & 0.44 & 10 \\
Calico Hills & $\alpha=0.29+3.19(\phi)$ & 0.01 & 4 \\
Formation & & & \\
& $n=0.89+0.81(\phi)$ & 0.98 & 4 \\
Vitrophyre & $\alpha=0.84-0.96(\phi)$ & 0.01 & 7 \\
& $n=1.40-1.21(\phi)$ & 0.05 & 7 \\
\hline
\end{tabular}

\section{SUMMARY AND CONCLUSIONS}

A set of data has been provided that includes physical- and hydrologic-flow property measurements on surface-outcrop samples from most of the rock units at Yucca Mountain. Observed porosity values range from 2 to 60 percent, and saturated hydraulicconductivity values range from $1 \mathrm{E}-12$ to $4 \mathrm{E}-6 \mathrm{~m} / \mathrm{s}$. The porosity range is much smaller within a lithologic unit. However, large variations may occur over very short vertical distances in the shardy-base subunit of the Tiva Canyon Tuff. In this unit, porosity changes from 15 percent to 55 percent within about $7.3 \mathrm{~m}$. Another example is the transition zone in the upper Topopah Spring Tuff, where the vitric caprock (4-percent porosity) changes abruptly to nonwelded tuff (39-percent porosity) over a vertical distance of a few centimeters. It is apparent that there are many subunits with distinct properties that could affect the estimation of ground-water flow through the unsaturated zone.

Porosity appears to be a reasonable surrogate or estimator for saturated hydraulic conductivity and possibly van Genuchten moisture-retention parameters for the welded and nonwelded tuffs. These relationships are different for the tuffs with higher water-holding capacity such as zeolitized Calico Hills Formation tuff and some of the nonwelded units that retain large vol- umes of water when dried under relative-humidity conditions. The relationship is also different for densely welded, highly vitric samples such as the vitric caprock or vitrophyres that have microfractures. These relationships appear to be useful for estimating properties and parameters for modeling water flow in the absence of complete data sets.

Previous hydrologic modeling efforts have used data from a few samples to devise parameters for models that consist of relatively few layers such as the Tiva Canyon Tuff, the bedded and nonwelded units of the Paintbrush Group, the Topopah Spring Tuff, and the tuffs of the Calico Hills Formation. The data in this report describe many subtleties and rapid gradational changes within these generalized hydrogeologic-flow units. These differences may require substantially more layers to adequately model water flow. Major geologic boundaries do not always reflect hydrologic differences, as in the upper Tiva Canyon Tuff welded and moderately welded units. The existence of very rapid vertical changes will probably require 2-dimensional or 3-dimensional models in several locations to predict the likely occurrence of lateral diversions of flow.

Although there have been some successful comparisons between properties measured on surface outcrop samples and those from borehole samples, it is generally not possible to collect both types of samples in the same location. Additionally, there is inherent lateral variability between sampling locations. Therefore, these samples may not represent the true physical and hydrologic property values that exist in the subsurface. However, there also have been studies that indicate that formation saturations throughout the unsaturated zone can be predicted using model parameters characterized from outcrop samples. Despite the limitations inherent in an outcrop study, there is little question that there is significant vertical, and much less lateral variability of physical and hydrologic properties at Yucca Mountain.

\section{REFERENCES}

American Society of Testing Materials, 1977, Adsorption and bulk specific gravity of natural building stone: American Society of Testing Materials, ANSI/ASTM R97-47 Annual Book of ASTM Standards, part 19.

Brooks, R.H., and Corey, A.T., 1964, Hydraulic properties of porous media: Fort Collins, Colorado State University, Hydrology Paper 3.

Brown, T.P., Lehman, L.L., Nieber, J.L., 1994, Testing conceptual unsaturated zone models for Yucca Mountain: Proceedings International High-Level Radioactive Waste Conference, Las Vegas, Nevada, May 22-26, 1994, p. 1999-2006. 
Buesch, D.C., Spengler, R.W., Moyer, T.C., and Geslin, J.K., (1996), Proposed revised stratigraphic nomenclature and macroscopic identification of lithostratigraphic units of the Paintbrush Group exposed at Yucca Mountain, Nevada: U.S. Geological Survey Open-File Report 94-469.

Bush, D.C., and Jenkins, R.E., 1970, Proper hydration of clays for rock property determinations: Journal of Petroleum Technology, v. 22, no. 7, p. 800-804.

Flint, A.L., and Flint, L.E., 1994, Spatial distribution of potential near-surface moisture flux at Yucca Mountain: Proceedings International High-Level Radioactive Waste Conference, Las Vegas, Nevada, May 22-26, 1994.

Flint, A.L., Flint, L.E., and Hevesi, J.A., 1993, Influence of long term climate change on net infiltration at Yucca Mountain, Nevada: Proceedings International HighLevel Radioactive Waste Conference, Las Vegas, Nevada, April 25-30, 1993.

Glass, R.J., Flint, A.L., Tidwell, V.C., Peplinski, W., Castro, Y., 1994, Fracture-matrix interaction in Topopah Spring tuff-Experiment and numerical simulation: Proceedings International High-Level Radio active Waste Conference, Las Vegas, Nevada, May 22-26, 1994.

Istok, J.D., Rautman, C.A., Flint, L.E., and Flint, A.L., 1994, Spatial variability in hydrologic properties of a volcanic tuff: Ground Water, v. 32, no. 5, p. 751-60.

Montazer, P., and Wilson, W.E., 1984, Conceptual hydrologic model of flow in the unsaturated zone, Yucca Mountain, Nevada: U.S. Geological Survey WaterResources Investigations Report 84-4345, 55 pp.

Nitao, J.J., Buscheck, T.A., Chestnut, D.A., 1992, The implications of episodic nonequilibrium fracture-matrix flow on site suitability and total site performance: Proceedings International High-Level Radioactive Waste Conference, Las Vegas, Nevada, April 12-16, 1992, p. 279-296.

Ortiz, T.S., Williams, R.L., Nimick, F.B., Whittet, B.C., and South, D.L., 1985, A three-dimensional model of refer- ence thermal/mechanical and hydrological stratigraphy at Yucca Mountain, southern Nevada: Albuquerque, N. Mex., Sandia National Laboratories, SAND84$1076,76 \mathrm{p}$.

Philip, J.R., 1957, The theory of infiltration 4. Sorptivity and algebraic infiltration equations: Soil Science, v. 84, p. 257-264.

Rautman, C.A., and Flint, A.L., 1992, Deterministic processes and stochastic modeling: Albuquerque, N. Mex., Sandia National Laboratories, SAND911925C.

Rautman, C.A., Flint, L.E., Flint, A.L., and Istok, J.D., Physical and hydrologic properties of outcrop samples from a nonwelded to welded tuff transition, Yucca Mountain, Nevada: U.S. Geological Survey Water-Resources Investigations Report 95-4061.

Sawyer, D.A., Flock, R.J., Lanphere, M.A., Warren, R.G., Broxton, D.E., and Hudson, M.R., 1994, Episodic calern volcanisms in the Miocene southwestern Nevada volcanic field-Revised stratigraphic framework, ${ }^{40} \mathrm{Ar} /{ }^{39} \mathrm{Ar}$ geochronology, and implications for magmatism and extension: Geologic Society American Bulletin, v. 106, no. N, p. 1304-1318.

Scott, R.B., and Bonk, J., 1984, Preliminary geologic map of Yucca Mountain with geologic sections, Nye County, Nevada: U.S. Geological Survey Open-File Report 84-494, scale 1:12,000.

Talsma, T., 1969, In-situ measurement of sorptivity: Australian Journal of Soil Research, v. 7, p. 269-276.

van Genuchten, M.Th., 1980, A closed-form equation for predicting the hydraulic conductivity of unsaturated soils: Soil Science Society of America Journal, v. 44 , p. $892-898$.

Wittwer, C.S., Bodvarsson, G.S., Chornack, M.P., Flint, A.L., Flint, L.E., Lewis, B.D., Spengler, R.W., and Rautman, C.A., 1992, Design of a threedimensional site-scale model for the unsaturated zone at Yucca Mountain, Nevada: Proceedings International High-Level Radioactive Waste Conference, Las Vegas, Nevada, April 12-16, 1992, p. 263-271. 


\section{APPENDIX I: DATA OF PHYSICAL PROPERTIES AND FLOW PROPERTIES FOR EIGHT OUTCROP TRANSECTS}


Table l-1. Solitario Canyon vertical transect physical properties, dry bulk density, porosity, and particle density calculated using relative-humidity oven and $105^{\circ} \mathrm{C}$ oven-dry weights; saturated hydraulic conductivity and sorptivity calculated from imbibition experiments on relative-humidity-dried samples. Estimates of saturated hydraulic conductivity done using regression equations in table 3.

\begin{tabular}{|c|c|c|c|c|c|c|c|c|c|c|c|}
\hline \multirow[b]{2}{*}{$\begin{array}{c}\text { Sample } \\
\text { ID }\end{array}$} & \multirow[b]{2}{*}{$\begin{array}{l}\text { Litho- } \\
\text { logy }\end{array}$} & \multirow[b]{2}{*}{$\begin{array}{l}\text { Tran- } \\
\text { sect } \\
\text { dis- } \\
\text { tance } \\
(\mathbf{m})\end{array}$} & \multicolumn{3}{|c|}{ Relative-humidity oven dried } & \multicolumn{3}{|c|}{$105^{\circ} \mathrm{C}$ oven dried } & \multirow{2}{*}{$\begin{array}{c}\text { Measured } \\
\text { saturated } \\
\text { hydraulic } \\
\text { conduc- } \\
\text { tivity } \\
\text { (m/s) }\end{array}$} & \multirow{2}{*}{$\begin{array}{c}\text { Estimated } \\
\text { saturated } \\
\text { hydraulic } \\
\text { conduc- } \\
\text { tivity } \\
(\mathrm{m} / \mathrm{s})\end{array}$} & \multirow{2}{*}{$\begin{array}{c}\text { RH- } \\
\text { dried } \\
\text { sorp- } \\
\text { tivity } \\
\left(\mathrm{m} / \mathrm{s}^{0.5}\right)\end{array}$} \\
\hline & & & $\begin{array}{c}\text { Dry } \\
\text { bulk } \\
\text { density } \\
\left(\mathbf{g} / \mathrm{cm}^{3}\right)\end{array}$ & $\begin{array}{c}\text { Porosity } \\
\left(\mathrm{cm}^{3} /\right. \\
\left.\mathrm{cm}^{3}\right)\end{array}$ & $\begin{array}{l}\text { Particle } \\
\text { density } \\
\left(\mathrm{g} / \mathrm{cm}^{3}\right)\end{array}$ & $\begin{array}{c}\text { Dry } \\
\text { bulk } \\
\text { density } \\
\left(\mathrm{g} / \mathrm{cm}^{3}\right)\end{array}$ & $\begin{array}{c}\text { Porosity } \\
\left(\mathrm{cm}^{3} /\right. \\
\left.\mathrm{cm}^{3}\right)\end{array}$ & $\begin{array}{l}\text { Particle } \\
\text { density } \\
\left(\mathrm{g} / \mathrm{cm}^{3}\right)\end{array}$ & & & \\
\hline TPC60 & cuc & 0.0 & 1.84 & 0.272 & 2.53 & 1.84 & 0.274 & 2.54 & $4.8 \mathrm{E}-07$ & & \\
\hline ТРС59 & cuc & 1.7 & 1.75 & 0.303 & 2.51 & 1.75 & 0.305 & 2.52 & & $2.1 E-07$ & \\
\hline ТPC58 & cuc & 1.7 & 1.80 & 0.279 & 2.50 & 1.80 & 0.282 & 2.51 & & $9.3 \mathrm{E}-08$ & \\
\hline TPC57 & cuc & 3.5 & 1.93 & 0.237 & 2.53 & 1.93 & 0.237 & 2.53 & $2.4 \mathrm{E}-07$ & & 9.7E-06 \\
\hline ТРC56 & cuc & 5.3 & 2.14 & 0.149 & 2.52 & 2.14 & 0.149 & 2.52 & & $2.5 \mathrm{E}-10$ & \\
\hline ТРC55-2 & cuc & 7.2 & 1.95 & 0.226 & 2.52 & 1.95 & 0.227 & 2.52 & 4.9E-08 & & \\
\hline ТРC54 & cuc & 9.3 & 2.12 & 0.156 & 2.51 & 2.12 & 0.157 & 2.52 & $8.7 E-11$ & & $6.0 \mathrm{E}-05$ \\
\hline ТРC53 & cul & 11.4 & 2.21 & 0.116 & 2.50 & 2.21 & 0.117 & 2.50 & $3.4 \mathrm{E}-11$ & & $2.8 \mathrm{E}-06$ \\
\hline ТPC52 & cul & 13.1 & 2.18 & 0.116 & 2.47 & 2.18 & 0.116 & 2.47 & & $3.6 \mathrm{E}-11$ & \\
\hline ТРC51 & cul & 14.5 & 2.21 & 0.106 & 2.47 & 2.21 & 0.107 & 2.48 & & $2.0 \mathrm{E}-11$ & \\
\hline ТРС50 & cul & 16.3 & 2.22 & 0.096 & 2.46 & 2.22 & 0.098 & 2.46 & $1.7 \mathrm{E}-12$ & & $9.2 \mathrm{E}-07$ \\
\hline TPC49 & cul & 18.9 & 2.29 & 0.053 & 2.41 & 2.28 & 0.059 & 2.42 & & $6.3 E-13$ & \\
\hline ТPC48 & cul & 18.9 & 2.26 & 0.067 & 2.42 & 2.26 & 0.068 & 2.43 & & $1.7 \mathrm{E}-12$ & \\
\hline ТPC47 & cul & 21.9 & 2.21 & 0.104 & 2.46 & 2.21 & 0.105 & 2.47 & & $1.8 \mathrm{E}-11$ & \\
\hline ТPC46-I & cul & 25.8 & 2.19 & 0.108 & 2.46 & 2.19 & 0.109 & 2.46 & & $2.2 \mathrm{E}-11$ & \\
\hline ТPC45 & cul & 26.4 & 2.19 & 0.105 & 2.45 & 2.19 & 0.107 & 2.46 & & $1.9 \mathrm{E}-11$ & \\
\hline ТРC44 & cks & 29.7 & 2.10 & 0.160 & 2.50 & 2.10 & 0.160 & 2.50 & & $4.4 \mathrm{E}-10$ & \\
\hline ТРC43 & cks & 30.8 & 2.21 & 0.103 & 2.46 & 2.20 & 0.104 & 2.46 & & $1.7 \mathrm{E}-11$ & \\
\hline ТРC42 & cks & 32.3 & 2.23 & 0.093 & 2.45 & 2.22 & 0.096 & 2.46 & & $9.3 \mathrm{E}-12$ & \\
\hline ТPC41 & cks & 34.3 & 2.23 & 0.093 & 2.46 & 2.23 & 0.095 & 2.46 & & $9.1 \mathrm{E}-12$ & \\
\hline ТPC40 & cks & 36.4 & 2.27 & 0.052 & 2.40 & 2.27 & 0.054 & 2.40 & & $6.0 \mathrm{E}-13$ & \\
\hline ТРС39 & cks & 41.3 & 2.23 & 0.095 & 2.47 & 2.23 & 0.097 & 2.47 & & $1.0 \mathrm{E}-11$ & \\
\hline ТРC38 & cks & 43.1 & 2.24 & 0.094 & 2.47 & 2.24 & 0.096 & 2.48 & $3.6 \mathrm{E}-12$ & & $1.4 \mathrm{E}-06$ \\
\hline ТРС37 & cks & 44.8 & 2.28 & 0.066 & 2.44 & 2.27 & 0.071 & 2.44 & & $1.5 \mathrm{E}-12$ & \\
\hline ТРC36 & $\mathrm{cks}$ & 47.4 & 2.30 & 0.035 & 2.38 & 2.29 & 0.041 & 2.39 & & $1.9 \mathrm{E}-13$ & \\
\hline ТРC35 & cks & 49.5 & 2.24 & 0.093 & 2.47 & 2.24 & 0.096 & 2.47 & & $8.9 \mathrm{E}-12$ & \\
\hline ТРС34 & cks & 54.4 & 2.32 & 0.061 & 2.47 & 2.31 & 0.064 & 2.47 & $2.7 \mathrm{E}-12$ & & $1.1 \mathrm{E}-06$ \\
\hline ТРС33 & cks & 56.5 & 2.24 & 0.093 & 2.47 & 2.23 & 0.096 & 2.47 & & $9.1 \mathrm{E}-12$ & \\
\hline ТРС 32 & cks & 59.6 & 2.29 & 0.070 & 2.47 & 2.29 & 0.076 & 2.47 & & $2.1 \mathrm{E}-12$ & \\
\hline ТРС30 & cks & 64.2 & 2.29 & 0.066 & 2.45 & 2.29 & 0.068 & 2.45 & & $1.6 \mathrm{E}-12$ & \\
\hline ТРС31 & cks & 64.2 & 2.30 & 0.062 & 2.46 & 2.30 & 0.063 & 2.46 & $2.8 \mathrm{E}-12$ & & $1.4 \mathrm{E}-06$ \\
\hline ТРС29 & cll & 65.1 & 2.14 & 0.140 & 2.48 & 2.14 & 0.140 & 2.48 & & $1.4 \mathrm{E}-10$ & \\
\hline ТРС28 & cll & 67.5 & 2.30 & 0.074 & 2.49 & 2.30 & 0.076 & 2.49 & & $2.7 \mathrm{E}-12$ & \\
\hline ТPC27 & cll & 69.5 & 2.17 & 0.118 & 2.46 & 2.17 & 0.119 & 2.47 & $1.3 \mathrm{E}-13$ & & $3.3 \mathrm{E}-06$ \\
\hline ТРС26 & cll & 72.5 & 2.01 & 0.188 & 2.48 & 2.01 & 0.189 & 2.48 & & $1.8 \mathrm{E}-09$ & \\
\hline ТPC25 & cll & 75.4 & 2.22 & 0.105 & 2.48 & 2.22 & 0.108 & 2.49 & & $1.9 \mathrm{E}-11$ & \\
\hline ТPC24 & cll & 78.5 & 2.34 & 0.061 & 2.49 & 2.34 & 0.063 & 2.50 & & $1.1 \mathrm{E}-12$ & \\
\hline ТРC23 & cll & 81.2 & 2.30 & 0.077 & 2.49 & 2.30 & 0.077 & 2.49 & & $3.3 \mathrm{E}-12$ & \\
\hline ТРC22-3 & cll & 84.6 & 2.33 & 0.064 & 2.49 & 2.33 & 0.065 & 2.50 & $2.0 \mathrm{E}-09$ & & $3.4 \mathrm{E}-06$ \\
\hline TPC21 & cll & 85.5 & 2.30 & 0.073 & 2.48 & 2.30 & 0.075 & 2.49 & & $2.5 \mathrm{E}-12$ & \\
\hline ТРC20 & cll & 88.1 & 2.28 & 0.076 & 2.47 & 2.28 & 0.078 & 2.47 & & $3.0 \mathrm{E}-12$ & \\
\hline ТРC 18 & cll & 89.3 & 2.31 & 0.063 & 2.47 & 2.31 & 0.065 & 2.47 & & $1.3 \mathrm{E}-12$ & \\
\hline ТPC19 & cll & 89.3 & 2.28 & 0.080 & 2.48 & 2.28 & 0.081 & 2.48 & & $4.0 \mathrm{E}-12$ & \\
\hline ТPC17 & cll & 91.0 & 2.37 & 0.042 & 2.48 & 2.37 & 0.045 & 2.48 & & $2.9 \mathrm{E}-13$ & \\
\hline
\end{tabular}


Table 1-1. Solitario Canyon vertical transect physical properties, dry bulk density, porosity, and particle density calculated using relative-humidity oven and $105^{\circ} \mathrm{C}$ oven-dry weights; saturated hydraulic conductivity and sorptivity calculated from imbibition experiments on relative-humidity-dried samples. Estimates of saturated hydraulic conductivity done using regression equations in table 3.--Continued

\begin{tabular}{|c|c|c|c|c|c|c|c|c|c|c|c|}
\hline \multirow[b]{2}{*}{$\begin{array}{l}\text { Sample } \\
\text { ID }\end{array}$} & \multirow[b]{2}{*}{$\begin{array}{l}\text { Litho- } \\
\text { logy }\end{array}$} & \multirow[b]{2}{*}{$\begin{array}{l}\text { Tran- } \\
\text { sect } \\
\text { dis- } \\
\text { tance } \\
(\mathbf{m})\end{array}$} & \multicolumn{3}{|c|}{ Relative-humidity oven dried } & \multicolumn{3}{|c|}{$105^{\circ} \mathrm{C}$ oven drled } & \multirow{2}{*}{$\begin{array}{l}\text { Measured } \\
\text { saturated } \\
\text { hydraulic } \\
\text { conduc- } \\
\text { tivity } \\
(\mathrm{m} / \mathrm{s})\end{array}$} & \multirow{2}{*}{$\begin{array}{l}\text { Estimated } \\
\text { saturated } \\
\text { hydraulic } \\
\text { conduc- } \\
\text { tivity } \\
(\mathrm{m} / \mathrm{s})\end{array}$} & \multirow{2}{*}{$\begin{array}{c}\text { RH- } \\
\text { drled } \\
\text { sorp- } \\
\text { tivity } \\
\left(\mathrm{m} / \mathrm{s}^{0.5}\right)\end{array}$} \\
\hline & & & $\begin{array}{c}\text { Dry } \\
\text { bulk } \\
\text { density } \\
\left(\mathbf{g} / \mathbf{c m}^{3}\right)\end{array}$ & $\begin{array}{c}\text { Porosity } \\
\left(\mathrm{cm}^{3} /\right. \\
\left.\mathrm{cm}^{3}\right)\end{array}$ & $\begin{array}{l}\text { Particle } \\
\text { density } \\
\left(\mathrm{g} / \mathrm{cm}^{3}\right)\end{array}$ & $\begin{array}{c}\text { Dry } \\
\text { bulk } \\
\text { density } \\
\left(\mathbf{g} / \mathrm{cm}^{3}\right)\end{array}$ & $\begin{array}{c}\text { Porosity } \\
\left(\mathrm{cm}^{3} /\right. \\
\left.\mathrm{cm}^{3}\right)\end{array}$ & $\begin{array}{l}\text { Particle } \\
\text { density } \\
\left(\mathrm{g} / \mathrm{cm}^{3}\right)\end{array}$ & & & \\
\hline TPC16 & cll & $\overline{93.4}$ & 2.34 & 0.057 & 2.49 & 2.34 & 0.059 & 2.49 & $3.8 \mathrm{E}-12$ & & $2.8 \mathrm{E}-06$ \\
\hline TPC15-2 & cll & 95.9 & 2.33 & 0.068 & 2.50 & 2.33 & 0.070 & 2.51 & & $1.8 \mathrm{E}-12$ & \\
\hline TPC13 & $\mathrm{ch}$ & 99.2 & 2.30 & 0.071 & 2.48 & 2.30 & 0.073 & 2.48 & & $2.2 \mathrm{E}-12$ & \\
\hline TPC14-2 & $\mathrm{ch}$ & 99.2 & 2.32 & 0.072 & 2.50 & 2.32 & 0.072 & 2.50 & & $2.3 \mathrm{E}-12$ & \\
\hline TPC 12 & ch & 101.5 & 2.35 & 0.053 & -2.48 & 2.35 & 0.055 & 2.48 & $3.6 \mathrm{E}-12$ & & $1.2 \mathrm{E}-06$ \\
\hline TPCII & $\mathrm{ch}$ & 104.1 & 2.35 & 0.044 & 2.46 & 2.35 & 0.047 & 2.47 & & $3.4 \mathrm{E}-13$ & \\
\hline TPC10 & $\mathrm{ch}$ & 105.8 & 2.35 & 0.049 & 2.48 & 2.35 & 0.052 & 2.48 & & $4.9 \mathrm{E}-13$ & \\
\hline ТРC9 & $\mathrm{ch}$ & 106.7 & 2.36 & 0.038 & 2.45 & 2.35 & 0.042 & 2.46 & & $2.3 \mathrm{E}-13$ & \\
\hline ТPC8 & $c c$ & 109.6 & 2.38 & 0.039 & 2.48 & 2.37 & 0.043 & 2.48 & $3.7 \mathrm{E}-13$ & & $7.1 \mathrm{E}-07$ \\
\hline TPC7 & $\mathrm{cc}$ & 111.6 & 2.37 & 0.049 & 2.50 & 2.37 & 0.052 & 2.50 & & $4.8 \mathrm{E}-13$ & \\
\hline ТPC6 & cc & 113.5 & 2.37 & 0.040 & 2.47 & 2.37 & 0.043 & 2.48 & & $2.6 \mathrm{E}-13$ & \\
\hline TPC5 & $\mathrm{cc}$ & 116.3 & 2.33 & 0.022 & 2.39 & 2.33 & 0.026 & 2.39 & $1.2 \mathrm{E}-08$ & & $5.4 \mathrm{E}-06$ \\
\hline TPC4 & cc & 117.8 & 2.30 & 0.024 & 2.36 & 2.29 & 0.030 & 2.36 & $1.5 \mathrm{E}-09$ & & \\
\hline TPC3 & cc & 120.2 & 2.33 & 0.021 & 2.38 & 2.33 & 0.027 & 2.39 & & $6.7 \mathrm{E}-14$ & \\
\hline TPC2 & $\mathrm{cv}$ & 123.7 & 2.31 & 0.030 & 2.38 & 2.31 & 0.031 & 2.38 & $4.5 \mathrm{E}-10$ & & $1.1 \mathrm{E}-06$ \\
\hline $\mathrm{TPCl}$ & $\mathrm{cv}$ & 125.7 & 2.09 & 0.110 & 2.34 & 2.08 & 0.111 & 2.34 & & $2.5 \mathrm{E}-11$ & \\
\hline BT27-IV & $\mathrm{ccb}$ & 126.2 & 1.93 & 0.172 & 2.33 & 1.86 & 0.232 & 2.42 & & $8.5 \mathrm{E}-10$ & \\
\hline BT27H & $\mathrm{ccb}$ & 126.2 & 1.98 & 0.155 & 2.34 & 1.94 & 0.181 & 2.37 & $4.2 \mathrm{E}-09$ & & $6.6 \mathrm{E}-06$ \\
\hline BT26H & $\mathrm{ccb}$ & 127.1 & 1.95 & 0.176 & 2.37 & 1.91 & 0.203 & 2.40 & & $1.0 \mathrm{E}-09$ & \\
\hline BT25H & $\mathrm{ccb}$ & 128.6 & 1.57 & 0.312 & 2.28 & 1.54 & 0.331 & 2.30 & $5.8 \mathrm{E}-08$ & & $3.1 \mathrm{E}-05$ \\
\hline BT25-2V & $\mathrm{ccb}$ & 128.6 & 1.55 & 0.317 & 2.27 & 1.52 & 0.346 & 2.32 & & $3.4 \mathrm{E}-07$ & \\
\hline BT25-1V & $\mathrm{ccb}$ & 128.6 & 1.59 & 0.296 & 2.26 & 1.55 & 0.328 & 2.31 & & $1.7 \mathrm{E}-07$ & \\
\hline BT24V & $\mathrm{ccb}$ & 129.8 & 1.40 & 0.391 & 2.30 & 1.37 & 0.409 & 2.32 & & $2.3 \mathrm{E}-06$ & \\
\hline ВТ24H & $\mathrm{ccb}$ & 129.8 & 1.40 & 0.388 & 2.29 & 1.37 & 0.407 & 2.32 & $2.0 \mathrm{E}-06$ & & $1.7 \mathrm{E}-04$ \\
\hline ВТ23H & $\mathrm{ccb}$ & 130.5 & 1.35 & 0.407 & 2.29 & 1.31 & 0.444 & 2.36 & $5.4 \mathrm{E}-06$ & & $2.7 \mathrm{E}-04$ \\
\hline BT23-1H & $\mathrm{ccb}$ & 130.5 & 1.39 & 0.392 & 2.29 & 1.35 & 0.419 & 2.33 & $3.6 \mathrm{E}-06$ & & $2.3 \mathrm{E}-04$ \\
\hline BT23V & $\mathrm{ccb}$ & 130.5 & 1.34 & 0.415 & 2.29 & 1.32 & 0.429 & 2.31 & & $3.6 \mathrm{E}-06$ & \\
\hline BT22V & $\mathrm{ccb}$ & 131.5 & 1.36 & 0.407 & 2.30 & 1.33 & 0.435 & 2.35 & & $3.2 \mathrm{E}-06$ & \\
\hline ВТ $22 \mathrm{H}$ & $c c b$ & 131.5 & 1.40 & 0.389 & 2.30 & 1.37 & 0.417 & 2.35 & $1.6 \mathrm{E}-06$ & & $7.0 \mathrm{E}-05$ \\
\hline BT21V & $\mathrm{ccb}$ & 132.3 & 1.36 & 0.411 & 2.31 & 1.32 & 0.448 & 2.39 & $4.4 \mathrm{E}-06$ & & 9.1E-05 \\
\hline BT $21 \mathrm{H}$ & $\mathrm{ccb}$ & 132.3 & 1.28 & 0.447 & 2.32 & 1.26 & 0.462 & 2.34 & & $5.8 \mathrm{E}-06$ & \\
\hline ВТ20H & $c c b$ & 133.5 & 0.97 & 0.582 & 2.32 & 0.93 & 0.617 & 2.42 & $5.5 \mathrm{E}-05$ & & $5.8 \mathrm{E}-04$ \\
\hline BT20V & $\mathrm{ccb}$ & 133.5 & 0.93 & 0.599 & 2.33 & 0.91 & 0.620 & 2.39 & & $7.8 \mathrm{E}-06$ & \\
\hline BT19H & $y m$ & 133.8 & 1.27 & 0.450 & 2.31 & 1.24 & 0.473 & 2.35 & & $6.0 \mathrm{E}-06$ & \\
\hline BT $18 \mathrm{H}$ & $y \mathrm{~m}$ & 134.3 & 1.34 & 0.412 & 2.28 & 1.30 & 0.440 & 2.32 & $1.3 \mathrm{E}-06$ & & $2.5 \mathrm{E}-04$ \\
\hline BT 17 & $\mathrm{ym}$ & 134.9 & 1.34 & 0.413 & 2.29 & 1.31 & 0.442 & 2.34 & $3.1 \mathrm{E}-06$ & & $9.3 \mathrm{E}-05$ \\
\hline BT 16V & $y m$ & 135.6 & 1.34 & 0.431 & 2.35 & 1.30 & 0.461 & 2.40 & & 4.7E-06 & \\
\hline BT 16H & $\mathrm{ym}$ & 135.6 & 1.26 & 0.440 & 2.26 & 1.24 & 0.463 & 2.30 & & 5.3E-06 & \\
\hline BT 15 & $\mathrm{ym}$ & 136.1 & 1.49 & 0.375 & 2.38 & 1.44 & 0.399 & 2.40 & & $1.6 \mathrm{E}-06$ & \\
\hline BT $14 \mathrm{H}$ & $\mathrm{pc}$ & 137.5 & 1.33 & 0.441 & 2.39 & 1.30 & 0.468 & 2.44 & & $5.4 \mathrm{E}-06$ & \\
\hline BT14V & $\mathrm{pc}$ & 137.5 & 1.32 & 0.444 & 2.38 & 1.29 & 0.463 & 2.41 & $2.0 \mathrm{E}-05$ & & $3.4 \mathrm{E}-04$ \\
\hline BTIIV & $\mathrm{pc}$ & 139.9 & 1.13 & 0.520 & 2.35 & 1.10 & 0.535 & 2.37 & & $1.0 \mathrm{E}-05$ & \\
\hline BTII & $\mathrm{pc}$ & 139.9 & 0.98 & 0.569 & 2.28 & 0.98 & 0.571 & 2.27 & $3.4 \mathrm{E}-06$ & & $4.5 \mathrm{E}-04$ \\
\hline BT32 & bt & 141.1 & 1.00 & 0.588 & 2.41 & 0.98 & 0.596 & 2.43 & & $8.5 \mathrm{E}-06$ & \\
\hline
\end{tabular}


Table I-1. Solitario Canyon vertical transect physical properties, dry bulk density, porosity, and particle density calculated using relative-humidity oven and $105^{\circ} \mathrm{C}$ oven-dry weights; saturated hydraulic conductivity and sorptivity calculated from imbibition experiments on relative-humidity-dried samples. Estimates of saturated hydraulic conductivity done using regression equations in table 3.--Continued

\begin{tabular}{|c|c|c|c|c|c|c|c|c|c|c|c|}
\hline \multirow[b]{2}{*}{$\begin{array}{c}\text { Sample } \\
\text { ID }\end{array}$} & \multirow[b]{2}{*}{$\begin{array}{l}\text { Litho- } \\
\text { logy }\end{array}$} & \multirow{2}{*}{$\begin{array}{l}\text { Tran- } \\
\text { sect } \\
\text { dis- } \\
\text { tance } \\
\text { (m) }\end{array}$} & \multicolumn{3}{|c|}{ Reiative-humidity oven dried } & \multicolumn{3}{|c|}{$105^{\circ} \mathrm{C}$ oven dried } & \multirow{2}{*}{$\begin{array}{l}\text { Measured } \\
\text { saturated } \\
\text { hydraulic } \\
\text { conduc- } \\
\text { tivity } \\
\text { (m/s) }\end{array}$} & \multirow{2}{*}{$\begin{array}{c}\text { Estimated } \\
\text { saturated } \\
\text { hydraulic } \\
\text { conduc- } \\
\text { tivity } \\
\text { (m/s) }\end{array}$} & \multirow{2}{*}{$\begin{array}{c}\text { RH- } \\
\text { dried } \\
\text { sorp- } \\
\text { tivity } \\
\left(\mathrm{m} / \mathrm{s}^{0.5}\right)\end{array}$} \\
\hline & & & $\begin{array}{c}\text { Dry } \\
\text { bulk } \\
\text { density } \\
\left(\mathbf{g} / \mathrm{cm}^{3}\right)\end{array}$ & $\begin{array}{c}\text { Porosity } \\
\left(\mathrm{cm}^{3} /\right. \\
\left.\mathrm{cm}^{3}\right)\end{array}$ & $\begin{array}{l}\text { Particle } \\
\text { density } \\
\left(\mathrm{g} / \mathrm{cm}^{3}\right)\end{array}$ & $\begin{array}{c}\text { Dry } \\
\text { bulk } \\
\text { density } \\
\left(\mathrm{g} / \mathrm{cm}^{3}\right)\end{array}$ & $\begin{array}{c}\text { Porosity } \\
\left(\mathrm{cm}^{3} /\right. \\
\left.\mathrm{cm}^{3}\right)\end{array}$ & $\begin{array}{l}\text { Particle } \\
\text { density } \\
\left(\mathrm{g} / \mathrm{cm}^{3}\right)\end{array}$ & & & \\
\hline BT10 & $\overline{b t}$ & i41.1 & 1.10 & 0.563 & 2.52 & 1.06 & 0.591 & 2.60 & & $9.8 \mathrm{E}-06$ & \\
\hline BT31 & bt & 141.3 & 0.92 & 0.618 & 2.42 & 0.90 & 0.635 & 2.47 & & $6.4 \mathrm{E}-06$ & \\
\hline BT30V & bt & 142.2 & 0.99 & 0.581 & 2.36 & 0.97 & 0.590 & 2.38 & & $8.9 \mathrm{E}-06$ & \\
\hline BT30V & bt & 142.2 & 1.03 & 0.562 & 2.35 & 1.01 & 0.571 & 2.36 & & $9.8 \mathrm{E}-06$ & \\
\hline ВТ29H & bt & 143.0 & 0.98 & 0.595 & 2.42 & 0.97 & 0.603 & 2.43 & & 8.1 E-06 & \\
\hline BT28 & bt & 143.6 & 0.91 & 0.617 & 2.37 & 0.89 & 0.623 & 2.36 & & $6.5 E-06$ & \\
\hline ВТ9Н & bt & 143.9 & 1.02 & 0.574 & 2.40 & 0.99 & 0.601 & 2.48 & & $9.3 \mathrm{E}-06$ & \\
\hline BT9V & bt & 143.9 & 1.07 & 0.549 & 2.37 & 1.04 & 0.572 & 2.44 & $3.3 \mathrm{E}-06$ & & 1.2E-04 \\
\hline ВT8H & bt & 144.5 & 1.15 & 0.525 & 2.42 & 1.13 & 0.540 & 2.46 & & $1.0 \mathrm{E}-05$ & \\
\hline BT8V & bt & 144.5 & 1.04 & 0.569 & 2.42 & 1.02 & 0.582 & 2.45 & & $9.5 \mathrm{E}-06$ & \\
\hline BT7-2H & bt & 146.0 & 1.11 & 0.544 & 2.43 & 1.09 & 0.556 & 2.46 & & $1.0 \mathrm{E}-05$ & \\
\hline BT7V & bt & 146.0 & 1.09 & 0.552 & 2.44 & 1.08 & 0.565 & 2.47 & & $1.0 \mathrm{E}-05$ & \\
\hline BT6 & bt & 146.8 & 1.67 & 0.349 & 2.56 & 1.65 & 0.355 & 2.57 & & 8.4E-07 & \\
\hline BT5V & bt & 147.5 & 1.53 & 0.383 & 2.48 & $1.5 \mathbf{i}$ & 0.392 & 2.48 & & $1.9 \mathrm{E}-06$ & \\
\hline BT4V & bt & 148.4 & 1.45 & 0.413 & 2.48 & 1.44 & 0.418 & 2.48 & & $3.5 \mathrm{E}-06$ & \\
\hline BT4H & bt & 148.4 & 1.53 & 0.387 & 2.50 & 1.52 & 0.390 & 2.49 & & $2.1 \mathrm{E}-06$ & \\
\hline ВT3H & bt & 148.7 & 1.61 & 0.369 & 2.55 & 1.60 & 0.370 & 2.54 & & $1.4 \mathrm{E}-06$ & \\
\hline BT3-3V & bt & 148.7 & 1.54 & 0.394 & 2.55 & 1.54 & 0.395 & 2.54 & $5.0 \mathrm{E}-07$ & & 8.3E-05 \\
\hline BT I & tc, vitric & 149.0 & 2.48 & 0.039 & 2.58 & 2.44 & 0.044 & 2.56 & & $2.5 \mathrm{E}-13$ & \\
\hline BT2 & tc, vitric & 149.0 & 2.45 & 0.054 & 2.59 & 2.41 & 0.058 & 2.55 & & $7.1 \mathrm{E}-13$ & \\
\hline TS59-1 & tc & 149.7 & 2.39 & 0.017 & 2.43 & 2.37 & 0.020 & 2.42 & & $5.2 \mathrm{E}-14$ & \\
\hline TS59-2 & tc & 149.7 & 2.37 & 0.024 & 2.43 & 2.36 & 0.026 & 2.42 & & $8.5 \mathrm{E}-14$ & \\
\hline TS58 & tc & 151.5 & 2.28 & 0.118 & 2.58 & 2.26 & 0.121 & 2.57 & $1.3 \mathrm{E}-09$ & & $1.5 \mathrm{E}-05$ \\
\hline TS57 & tr & 153.6 & 2.22 & 0.134 & 2.57 & 2.21 & 0.138 & 2.56 & & $1.1 \mathrm{E}-10$ & \\
\hline TS56 & $\mathrm{tr}$ & 155.6 & 2.20 & 0.148 & 2.58 & 2.18 & 0.152 & 2.57 & $4.2 \mathrm{E}-07$ & & $2.2 \mathrm{E}-05$ \\
\hline TS55 & tr & 158.2 & 2.24 & 0.125 & 2.56 & 2.22 & 0.128 & 2.55 & & $6.2 \mathrm{E}-11$ & \\
\hline TS54 & tr & 160.5 & 2.17 & 0.149 & 2.55 & 2.16 & 0.151 & 2.54 & 2.7E-09 & & $1.9 \mathrm{E}-05$ \\
\hline TS53 & $\operatorname{tr}$ & 162.3 & 2.16 & 0.155 & 2.56 & 2.13 & 0.157 & 2.52 & & $3.4 \mathrm{E}-10$ & \\
\hline TS52 & $\mathrm{tr}$ & 163.4 & 2.20 & 0.143 & 2.57 & 2.18 & 0.144 & 2.55 & 4.7E-09 & & \\
\hline TS51 & tr & 165.8 & 2.22 & 0.131 & 2.56 & 2.21 & 0.131 & 2.54 & & $8.8 \mathrm{E}-11$ & \\
\hline TS50 & $\operatorname{tr}$ & 167.9 & 2.18 & 0.145 & 2.55 & 2.17 & 0.147 & 2.55 & 5.5E-09 & & $1.9 \mathrm{E}-05$ \\
\hline TS49 & $\operatorname{tr}$ & 170.5 & 2.27 & 0.109 & 2.54 & 2.25 & 0.112 & 2.54 & & $2.4 \mathrm{E}-11$ & \\
\hline TS48 & tr & 173.1 & 2.17 & 0.150 & 2.55 & 2.15 & 0.152 & 2.54 & & $2.6 \mathrm{E}-10$ & \\
\hline TS46 & tul & 176.3 & 2.04 & 0.192 & 2.52 & 2.02 & 0.195 & 2.51 & & 2.3E-09 & \\
\hline TS45 & tul & 182.7 & 2.14 & 0.151 & 2.52 & 2.13 & 0.155 & 2.51 & & $2.7 \mathrm{E}-10$ & \\
\hline TS44 & tul & 183.8 & 2.16 & 0.140 & 2.52 & 2.15 & 0.142 & 2.50 & & $1.5 \mathrm{E}-10$ & \\
\hline TS43 & tul & 186.5 & 1.96 & 0.214 & 2.49 & 1.94 & 0.216 & 2.47 & & $6.6 \mathrm{E}-09$ & \\
\hline TS42 & tul & 188.7 & 2.19 & 0.133 & 2.53 & 2.17 & 0.136 & 2.51 & & 9.7E-11 & \\
\hline TS41 & tul & 192.6 & 2.04 & 0.188 & 2.51 & 2.01 & 0.191 & 2.49 & & $1.9 \mathrm{E}-09$ & \\
\hline TS40 & tul & 194.5 & 2.11 & 0.156 & 2.50 & 2.10 & 0.159 & 2.49 & $5.5 \mathrm{E}-10$ & & $7.8 \mathrm{E}-06$ \\
\hline TS39 & tul & 196.9 & 2.17 & 0.124 & 2.48 & 2.16 & 0.128 & 2.48 & & $5.9 \mathrm{E}-11$ & \\
\hline TS38 & tul & 198.7 & 2.13 & 0.145 & 2.49 & 2.12 & 0.147 & 2.48 & & $1.9 \mathrm{E}-10$ & \\
\hline TS37 & tul & 200.9 & 2.08 & 0.164 & 2.49 & 2.06 & 0.169 & 2.48 & & $5.4 \mathrm{E}-10$ & \\
\hline TS36 & tul & 203.3 & 2.13 & 0.146 & 2.50 & 2.12 & 0.150 & 2.49 & & $2.1 \mathrm{E}-10$ & \\
\hline
\end{tabular}


Table 1-1. Solitario Canyon vertical transect physical properties, dry bulk density, porosity, and particle density calculated using relative-humidity oven and $105^{\circ} \mathrm{C}$ oven-dry weights; saturated hydraulic conductivity and sorptivity calculated from imbibition experiments on relative-humidity-dried samples. Estimates of saturated hydraulic conductivity done using regression equations in table 3.--Continued

\begin{tabular}{|c|c|c|c|c|c|c|c|c|c|c|c|}
\hline \multirow[b]{2}{*}{$\begin{array}{c}\text { Sample } \\
\text { ID }\end{array}$} & \multirow[b]{2}{*}{$\begin{array}{l}\text { Litho- } \\
\text { logy }\end{array}$} & \multirow[b]{2}{*}{$\begin{array}{l}\text { Tran- } \\
\text { sect } \\
\text { dis- } \\
\text { tance } \\
(m)\end{array}$} & \multicolumn{3}{|c|}{ Relative-humidity oven dried } & \multicolumn{3}{|c|}{$105^{\circ} \mathrm{C}$ oven dried } & \multirow{2}{*}{$\begin{array}{l}\text { Measured } \\
\text { saturated } \\
\text { hydraulic } \\
\text { conduc- } \\
\text { tivity } \\
(\mathrm{m} / \mathrm{s})\end{array}$} & \multirow{2}{*}{$\begin{array}{l}\text { Estimated } \\
\text { saturated } \\
\text { hydraulic } \\
\text { conduc- } \\
\text { tivity } \\
(\mathrm{m} / \mathrm{s})\end{array}$} & \multirow[b]{2}{*}{$\begin{array}{c}\text { RH- } \\
\text { dried } \\
\text { sorp- } \\
\text { tivity } \\
\left(\mathrm{m} / \mathrm{s}^{0.5}\right)\end{array}$} \\
\hline & & & $\begin{array}{c}\text { Dry } \\
\text { bulk } \\
\text { density } \\
\left(\mathrm{g} / \mathrm{cm}^{3}\right)\end{array}$ & $\begin{array}{c}\text { Porosity } \\
\left(\mathrm{cm}^{3} /\right. \\
\left.\mathrm{cm}^{3}\right)\end{array}$ & $\begin{array}{l}\text { Particle } \\
\text { density } \\
\left(g / \mathrm{cm}^{3}\right)\end{array}$ & $\begin{array}{c}\text { Dry } \\
\text { bulk } \\
\text { density } \\
\left(\mathbf{g} / \mathrm{cm}^{3}\right)\end{array}$ & $\begin{array}{c}\text { Porosity } \\
\begin{array}{c}\left(\mathrm{cm}^{3} /\right. \\
\left.\mathrm{cm}^{3}\right)\end{array}\end{array}$ & $\begin{array}{l}\text { Particle } \\
\text { density } \\
\left(g / \mathrm{cm}^{3}\right)\end{array}$ & & & \\
\hline TS35 & tul & 205.9 & 2.11 & 0.152 & 2.48 & 2.09 & 0.156 & 2.48 & & $2.9 \mathrm{E}-10$ & \\
\hline TS34 & tul & 207.9 & 2.15 & 0.162 & 2.57 & 2.14 & 0.165 & 2.56 & & $4.8 \mathrm{E}-10$ & \\
\hline TS33 & tul & 210.8 & 2.09 & 0.156 & 2.48 & 2.07 & 0.160 & 2.47 & & $3.5 \mathrm{E}-10$ & \\
\hline TS32 & tul & 212.4 & 2.19 & 0.120 & 2.49 & 2.18 & 0.124 & 2.49 & 4.1E-12 & & $2.6 \mathrm{E}-06$ \\
\hline TS31 & tul & 215.2 & 2.17 & 0.129 & 2.49 & 2.14 & 0.133 & 2.47 & & $8.0 \mathrm{E}-11$ & \\
\hline TS30 & tul & 215.2 & 2.23 & 0.104 & 2.49 & 2.21 & 0.108 & 2.48 & & $1.8 \mathrm{E}-11$ & \\
\hline TS29 & tul & 217.9 & 2.24 & 0.099 & 2.49 & 2.23 & 0.103 & 2.48 & $5.5 \mathrm{E}-13$ & & $3.7 \mathrm{E}-06$ \\
\hline TS28 & tul & 219.5 & 2.24 & 0.100 & 2.49 & 2.22 & 0.104 & 2.48 & & $1.4 \mathrm{E}-11$ & \\
\hline TS27 & tul & 221.1 & 2.28 & 0.085 & 2.49 & 2.26 & 0.089 & 2.48 & & $5.6 \mathrm{E}-12$ & \\
\hline TS26 & tul & 223.1 & 2.17 & 0.129 & 2.49 & 2.16 & 0.131 & 2.48 & $3.2 \mathrm{E}-11$ & & $3.6 \mathrm{E}-06$ \\
\hline TS26-2 & tul & 223.1 & 2.18 & 0.124 & 2.49 & 2.17 & 0.126 & 2.48 & & $6.0 \mathrm{E}-11$ & \\
\hline TS25 & tul & 225.9 & 2.21 & 0.113 & 2.49 & 2.19 & 0.115 & 2.47 & & 3.1E-11 & \\
\hline TS24 & tul & 228.0 & 2.08 & 0.167 & 2.50 & 2.06 & 0.170 & 2.48 & & $6.5 \mathrm{E}-10$ & \\
\hline TS23 & tul & 229.8 & 2.26 & 0.082 & 2.46 & 2.23 & 0.092 & 2.45 & & $4.5 \mathrm{E}-12$ & \\
\hline TS22 & tul & 232.4 & 2.32 & 0.065 & 2.48 & 2.29 & 0.069 & 2.46 & & $1.5 \mathrm{E}-12$ & \\
\hline TS21-2 & tul & 235.0 & 2.31 & 0.077 & 2.50 & 2.26 & 0.083 & 2.47 & & $3.3 \mathrm{E}-12$ & \\
\hline TS21-1 & tul & 235.0 & 2.26 & 0.096 & 2.50 & .2 .22 & 0.100 & 2.47 & & $1.1 \mathrm{E}-11$ & \\
\hline TS20 & tul & 237.1 & 2.32 & 0.066 & 2.48 & 2.29 & 0.072 & 2.47 & & $1.6 \mathrm{E}-12$ & \\
\hline TS19 & tul & 239.9 & 2.36 & 0.058 & 2.50 & 2.31 & 0.063 & 2.47 & & $8.9 \mathrm{E}-13$ & \\
\hline TS 18 & tul & 242.9 & 2.34 & 0.058 & 2.48 & 2.31 & 0.064 & 2.46 & & $9.2 \mathrm{E}-13$ & \\
\hline TS17 & tul & 245.7 & 2.35 & 0.064 & 2.51 & 2.32 & 0.068 & 2.50 & & $1.4 \mathrm{E}-12$ & \\
\hline TS16 & $\mathrm{tmn}$ & 246.7 & 2.21 & 0.105 & 2.47 & 2.20 & 0.107 & 2.46 & & $1.8 \mathrm{E}-11$ & \\
\hline TS15 & $\mathrm{tmn}$ & 249.2 & 2.21 & 0.109 & 2.48 & 2.20 & 0.110 & 2.47 & & $2.4 \mathrm{E}-11$ & \\
\hline TS14 & $\operatorname{tmn}$ & 252.4 & 2.22 & 0.095 & 2.46 & 2.21 & 0.101 & 2.45 & & $1.0 \mathrm{E}-11$ & \\
\hline $\mathrm{TS} 13$ & $\mathrm{tmn}$ & 255.1 & 2.22 & 0.102 & 2.48 & 2.21 & 0.107 & 2.47 & & $1.5 \mathrm{E}-11$ & \\
\hline $\mathrm{TS} 12$ & $\mathrm{tmn}$ & 257.9 & 2.28 & 0.095 & 2.52 & 2.26 & 0.099 & 2.51 & & $1.0 \mathrm{E}-11$ & \\
\hline TSII & $\mathrm{tmn}$ & 263.3 & 2.31 & 0.070 & 2.49 & 2.28 & 0.073 & 2.46 & & $2.0 \mathrm{E}-12$ & \\
\hline TSIO & tll & 265.9 & 2.36 & 0.049 & 2.48 & 2.33 & 0.055 & 2.47 & & $5.0 \mathrm{E}-13$ & \\
\hline TS9 & tll & 267.9 & 2.36 & 0.059 & 2.50 & 2.34 & 0.064 & 2.50 & & $9.5 \mathrm{E}-13$ & \\
\hline TS8 & $t \mid 1$ & 275.2 & 2.35 & 0.075 & 2.54 & 2.32 & 0.077 & 2.51 & & $2.8 \mathrm{E}-12$ & \\
\hline TS7 & tll & 281.5 & 2.35 & 0.089 & 2.58 & 2.32 & 0.092 & 2.56 & $6.8 \mathrm{E}-12$ & & \\
\hline TS6 & tll & 285.6 & 2.34 & 0.092 & 2.58 & 2.31 & 0.096 & 2.56 & $8.2 \mathrm{E}-12$ & & \\
\hline TS5 & tll & 289.9 & 2.36 & 0.078 & 2.56 & 2.34 & 0.083 & 2.55 & $3.4 \mathrm{E}-12$ & & \\
\hline TS4 & tll & 293.8 & 2.32 & 0.063 & 2.48 & 2.30 & 0.072 & 2.48 & $1.3 \mathrm{E}-12$ & & \\
\hline TS3 & tll & 301.4 & 2.34 & 0.066 & 2.50 & 2.32 & 0.070 & 2.50 & $1.6 \mathrm{E}-12$ & & \\
\hline TS2 & tll & 303.7 & 2.35 & 0.062 & 2.50 & 2.33 & 0.067 & 2.50 & $1.2 \mathrm{E}-12$ & & \\
\hline TSI & tll & 314.6 & 2.29 & 0.035 & 2.37 & 2.24 & 0.064 & 2.39 & $1.8 \mathrm{E}-13$ & & \\
\hline
\end{tabular}


Table 1-2. Busted Butte vertical transect physical properties, dry bulk density, porosity, and particle density calculated using relative-humidity oven and $105^{\circ} \mathrm{C}$ oven-dry weights; saturated hydraulic conductivity and sorptivity calculated from imbibition experiments on relative-humidity-dried samples

\begin{tabular}{|c|c|c|c|c|c|c|c|c|c|}
\hline \multirow[b]{2}{*}{$\begin{array}{c}\text { Sample } \\
\text { ID }\end{array}$} & \multirow[b]{2}{*}{ Llthoiogy } & \multirow[b]{2}{*}{$\begin{array}{l}\text { Transect } \\
\text { dlstance } \\
\text { (m) }\end{array}$} & \multicolumn{3}{|c|}{ Relatlve-humldity oven dried } & \multicolumn{3}{|c|}{$105^{\circ} \mathrm{C}$ oven drled } & \multirow{2}{*}{$\begin{array}{c}\text { Saturated } \\
\text { hydraullc } \\
\text { conductlvity } \\
(\mathbf{m} / \mathbf{s})\end{array}$} \\
\hline & & & $\begin{array}{l}\text { Dry bulk } \\
\text { density } \\
\left(\mathrm{g} / \mathrm{cm}^{3}\right)\end{array}$ & $\begin{array}{l}\text { Porosity } \\
\left(\mathrm{cm}^{3} / \mathrm{cm}^{3}\right)\end{array}$ & $\begin{array}{l}\text { Partlcle } \\
\text { density } \\
\left(\mathrm{g} / \mathrm{cm}^{3}\right)\end{array}$ & $\begin{array}{l}\text { Dry buik } \\
\text { density } \\
\left(g / \mathrm{cm}^{3}\right)\end{array}$ & $\begin{array}{c}\text { Porosity } \\
\left(\mathrm{cm}^{3} / \mathrm{cm}^{3}\right)\end{array}$ & $\begin{array}{l}\text { Partlcie } \\
\text { density } \\
\left(9 / \mathrm{cm}^{3}\right)\end{array}$ & \\
\hline BB101 & tn & 173.4 & 1.98 & 0.174 & 2.40 & 1.96 & 0.196 & 2.43 & $4.2 \mathrm{E}-10$ \\
\hline BB 100 & tn & 172.8 & 1.67 & 0.304 & 2.40 & 1.66 & 0.309 & 2.40 & $6.5 \mathrm{E}-09$ \\
\hline BB 102 & tc, vitric & 171.9 & 2.36 & 0.045 & 2.47 & 2.35 & 0.049 & 2.47 & $1.7 \mathrm{E}-09$ \\
\hline BB99 & tc, vitric & 171.9 & 2.32 & 0.042 & 2.42 & 2.32 & 0.045 & 2.43 & \\
\hline BB98 & tc, vitric & 171.0 & 2.30 & 0.046 & 2.41 & 2.29 & 0.049 & 2.41 & $2.6 \mathrm{E}-10$ \\
\hline BB97 & tc & 169.5 & 2.16 & 0.132 & 2.48 & 2.15 & 0.136 & 2.49 & \\
\hline BB96 & tc & 167.9 & 2.16 & 0.135 & 2.50 & 2.15 & 0.142 & 2.51 & $2.9 \mathrm{E}-08$ \\
\hline BB95 & $\mathbf{t r}$ & 166.1 & 2.11 & 0.139 & 2.46 & 2.11 & 0.140 & 2.46 & 8.2E-10 \\
\hline BB94 & $\mathbf{t r}$ & 164.9 & 2.02 & 0.170 & 2.43 & 2.02 & 0.170 & 2.43 & $1.6 \mathrm{E}-10$ \\
\hline BB93 & $\mathbf{t r}$ & 162.8 & 2.18 & 0.123 & 2.49 & 2.18 & 0.124 & 2.49 & \\
\hline BB92 & tr & 160.3 & 2.14 & 0.118 & 2.42 & 2.14 & 0.119 & 2.42 & \\
\hline BB91 & $\mathbf{t r}$ & 158.5 & 2.02 & 0.181 & 2.47 & 2.02 & 0.181 & 2.47 & \\
\hline BB 90 & tul & 154.8 & 2.22 & 0.092 & 2.44 & 2.21 & 0.096 & 2.45 & \\
\hline BB89 & tul & 153.0 & 2.12 & 0.131 & 2.44 & 2.12 & 0.135 & 2.45 & $5.4 \mathrm{E}-12$ \\
\hline BB88 & tul & 151.5 & 2.19 & 0.098 & 2.43 & 2.19 & 0.104 & 2.44 & \\
\hline BB87 & tul & 150.0 & 2.10 & 0.151 & 2.47 & 2.09 & 0.155 & 2.48 & \\
\hline BB86 & tul & 148.4 & 2.26 & 0.077 & 2.44 & 2.25 & 0.084 & 2.45 & $1.8 \mathrm{E}-12$ \\
\hline BB85 & tul & 146.3 & 2.25 & 0.080 & 2.44 & 2.24 & 0.084 & 2.45 & \\
\hline BB84 & tul & 144.8 & 2.09 & 0.151 & 2.46 & 2.08 & 0.161 & 2.48 & \\
\hline BB83 & tul & 141.1 & 2.22 & 0.096 & 2.46 & 2.21 & 0.101 & 2.46 & \\
\hline BB82 & tul & 139.0 & 2.24 & 0.095 & 2.48 & 2.24 & 0.099 & 2.49 & \\
\hline BB81 & tul & 137.5 & 2.20 & 0.105 & 2.46 & 2.20 & 0.111 & 2.47 & \\
\hline BB80 & tul & 133.2 & 2.38 & 0.050 & 2.50 & 2.38 & 0.053 & 2.51 & \\
\hline BB79 & tul & 131.4 & 2.22 & 0.106 & 2.48 & 2.22 & 0.111 & 2.49 & \\
\hline BB78 & tul & 130.1 & 2.13 & 0.144 & 2.49 & 2.12 & 0.152 & 2.50 & \\
\hline BB77 & tul & 129.2 & 2.15 & 0.140 & 2.50 & 2.14 & 0.147 & 2.51 & \\
\hline BB76 & tul & 126.8 & 2.16 & 0.130 & 2.48 & 2.15 & 0.137 & 2.50 & \\
\hline BB75 & tul & 125.9 & 2.29 & 0.068 & 2.46 & 2.29 & 0.076 & 2.47 & \\
\hline BB74 & tul & 124.4 & 2.33 & 0.076 & 2.52 & 2.32 & 0.085 & 2.54 & \\
\hline BB73 & tul & 122.5 & 2.25 & 0.104 & 2.51 & 2.25 & 0.107 & 2.52 & \\
\hline BB72 & tul & 121.3 & 2.29 & 0.086 & 2.51 & 2.29 & 0.090 & 2.51 & \\
\hline BB71 & tul & 119.2 & 2.33 & 0.065 & 2.49 & 2.32 & 0.070 & 2.50 & \\
\hline BB70 & tul & 116.7 & 2.34 & 0.057 & 2.48 & 2.33 & 0.064 & 2.49 & $3.2 \mathrm{E}-12$ \\
\hline BB69 & tul & 99.4 & 2.34 & 0.063 & 2.49 & 2.33 & 0.067 & 2.50 & \\
\hline BB68 & $\mathrm{tmn}$ & 96.3 & 2.34 & 0.063 & 2.49 & 2.33 & 0.070 & 2.50 & \\
\hline BB67 & $\mathrm{tmn}$ & 95.1 & 2.30 & 0.085 & 2.51 & 2.29 & 0.091 & 2.52 & \\
\hline BB66 & $\mathrm{tmn}$ & 90.2 & 2.23 & 0.078 & 2.42 & 2.23 & 0.083 & 2.43 & \\
\hline BB65 & $\mathrm{tmn}$ & 86.9 & 2.02 & 0.172 & 2.44 & 2.02 & 0.175 & 2.45 & \\
\hline BB64 & $\mathrm{tmn}$ & 84.4 & 2.05 & 0.177 & 2.49 & 2.04 & 0.180 & 2.49 & \\
\hline BB63 & $\mathrm{tmn}$ & 81.4 & 2.24 & 0.064 & 2.39 & 2.23 & 0.073 & 2.40 & \\
\hline BB60 & tll & 71.0 & 2.25 & 0.067 & 2.42 & 2.25 & 0.072 & 2.42 & \\
\hline BB59 & tll & 68.6 & 2.36 & 0.051 & 2.49 & 2.35 & 0.060 & 2.50 & \\
\hline
\end{tabular}


Table 1-2. Busted Butte vertical transect physical properties, dry bulk density, porosity, and particle density calculated using relative-humidity oven and $105^{\circ} \mathrm{C}$ oven-dry weights; saturated hydraulic conductivity and sorptivity calculated from imbibition experiments on relative-humidity-dried samples--Continued

\begin{tabular}{|c|c|c|c|c|c|c|c|c|c|}
\hline \multirow[b]{2}{*}{$\begin{array}{c}\text { Sample } \\
\text { ID }\end{array}$} & \multirow[b]{2}{*}{ Lithology } & \multirow{2}{*}{$\begin{array}{l}\text { Transect } \\
\text { distance } \\
\text { (m) }\end{array}$} & \multicolumn{3}{|c|}{ Relative-humidity oven dried } & \multicolumn{3}{|c|}{$105^{\circ} \mathrm{C}$ oven dried } & \multirow{2}{*}{$\begin{array}{c}\text { Saturated } \\
\text { hydraulic } \\
\text { conductivity } \\
\text { (m/s) }\end{array}$} \\
\hline & & & $\begin{array}{l}\text { Dry buik } \\
\text { density } \\
\left(\mathrm{g} / \mathrm{cm}^{3}\right)\end{array}$ & $\begin{array}{l}\text { Porosity } \\
\left(\mathrm{cm}^{3} / \mathrm{cm}^{3}\right)\end{array}$ & $\begin{array}{l}\text { Particle } \\
\text { density } \\
\left(\mathrm{g} / \mathrm{cm}^{3}\right)\end{array}$ & $\begin{array}{l}\text { Dry buik } \\
\text { density } \\
\left(g / \mathrm{cm}^{3}\right)\end{array}$ & $\begin{array}{l}\text { Porosity } \\
\left(\mathrm{cm}^{3} / \mathrm{cm}^{3}\right)\end{array}$ & $\begin{array}{l}\text { Particie } \\
\text { density } \\
\left(\mathrm{g} / \mathrm{cm}^{3}\right)\end{array}$ & \\
\hline BB58 & til & 66.4 & 2.30 & 0.072 & 2.48 & 2.30 & 0.076 & 2.49 & \\
\hline BB57 & tll & 64.9 & 2.35 & 0.068 & 2.52 & 2.34 & 0.073 & 2.53 & \\
\hline BB56 & tll & 62.8 & 2.34 & 0.066 & 2.50 & 2.33 & 0.073 & 2.51 & \\
\hline BB55 & tll & 60.7 & 2.33 & 0.060 & 2.47 & 2.32 & 0.064 & 2.48 & \\
\hline BB54 & tll & 59.7 & 2.26 & 0.090 & 2.49 & 2.26 & 0.095 & 2.49 & $4.0 \mathrm{E}-13$ \\
\hline BB53 & tll & 57.0 & 2.32 & 0.061 & 2.47 & 2.31 & 0.067 & 2.48 & \\
\hline BB52 & tll & 55.5 & 2.34 & 0.023 & 2.40 & 2.34 & 0.029 & 2.41 & \\
\hline BB51 & tll & 53.6 & 2.32 & 0.059 & 2.47 & 2.32 & 0.066 & 2.48 & \\
\hline BB50 & tll & 50.6 & 2.33 & 0.065 & 2.49 & 2.33 & 0.072 & 2.51 & \\
\hline BB49 & tll & 48.2 & 2.35 & 0.077 & 2.55 & 2.35 & 0.078 & 2.55 & \\
\hline BB48 & tll & 46.3 & 2.07 & 0.170 & 2.50 & 2.07 & 0.173 & 2.50 & \\
\hline BB47 & tll & 44.8 & 2.33 & 0.078 & 2.53 & 2.32 & 0.086 & 2.54 & \\
\hline BB46 & tll & 42.7 & 2.32 & 0.064 & 2.48 & 2.32 & 0.069 & 2.49 & \\
\hline BB45 & tll & 40.5 & 2.18 & 0.123 & 2.48 & 2.17 & 0.129 & 2.50 & \\
\hline BB44 & tll & 38.7 & 2.35 & 0.057 & 2.49 & 2.34 & 0.067 & 2.51 & \\
\hline BB43 & tll & 37.5 & 2.32 & 0.064 & 2.47 & 2.30 & 0.075 & 2.49 & \\
\hline BB42 & tll & 36.6 & 2.32 & 0.062 & 2.48 & 2.32 & 0.069 & 2.49 & \\
\hline BB41C & tll & 35.4 & 2.33 & 0.057 & 2.47 & 2.32 & 0.068 & 2.49 & \\
\hline BB40 & tll & 34.4 & 2.28 & 0.054 & 2.41 & 2.28 & 0.058 & 2.42 & \\
\hline BB39 & tll & 33.5 & 2.28 & 0.078 & 2.48 & 2.27 & 0.088 & 2.49 & \\
\hline BB38 & tll & 32.6 & 1.99 & 0.203 & 2.50 & 1.99 & 0.204 & 2.50 & \\
\hline BB37 & tll & 32.0 & 2.20 & 0.116 & 2.49 & 2.19 & 0.127 & 2.50 & $1.2 \mathrm{E}-10$ \\
\hline BB36 & tll & 31.1 & 2.32 & 0.074 & 2.50 & 2.31 & 0.083 & 2.52 & \\
\hline BB35 & tll & 31.1 & 2.32 & 0.068 & 2.49 & 2.32 & 0.073 & 2.50 & \\
\hline BB34 & tll & 30.2 & 2.28 & 0.102 & 2.54 & 2.27 & 0.110 & 2.55 & \\
\hline BB33 & tll & 29.3 & 2.32 & 0.068 & 2.49 & 2.31 & 0.075 & 2.50 & 4.5E-13 \\
\hline BB32 & tll & 28.0 & 2.33 & 0.084 & 2.55 & 2.33 & 0.088 & 2.55 & \\
\hline BB31 & tll & 26.8 & 2.35 & 0.091 & 2.59 & 2.35 & 0.095 & 2.59 & \\
\hline BB30 & tll & 25.3 & 2.36 & 0.080 & 2.57 & 2.36 & 0.086 & 2.58 & \\
\hline BB29 & tll & 24.4 & 2.34 & 0.073 & 2.52 & 2.33 & 0.083 & 2.54 & \\
\hline BB28 & tll & 23.2 & 1.98 & 0.207 & 2.50 & 1.98 & 0.207 & 2.50 & \\
\hline BB27 & tll & 22.6 & 2.30 & 0.061 & 2.45 & 2.29 & 0.069 & 2.46 & \\
\hline BB26 & tll & 21.6 & 2.34 & 0.076 & 2.53 & 2.33 & 0.083 & 2.54 & \\
\hline BB25 & tll & 21.0 & 2.08 & 0.167 & 2.49 & 2.08 & 0.168 & 2.50 & \\
\hline BB24 & $\mathrm{tm}$ & 20.1 & 2.34 & 0.091 & 2.57 & 2.34 & 0.096 & 2.58 & \\
\hline BB23 & $\mathrm{tm}$ & 19.5 & 2.34 & 0.088 & 2.57 & 2.34 & 0.091 & 2.57 & \\
\hline BB22A & $\mathrm{tm}$ & 18.6 & 2.34 & 0.068 & 2.51 & 2.34 & 0.074 & 2.52 & \\
\hline BB22 & $\mathrm{tm}$ & 18.6 & 2.34 & 0.067 & 2.51 & 2.33 & 0.078 & 2.53 & \\
\hline BB21 & $\mathrm{tm}$ & 18.0 & 2.31 & 0.068 & 2.47 & 2.30 & 0.073 & 2.48 & \\
\hline BB20 & $\mathrm{tm}$ & 17.4 & 2.35 & 0.066 & 2.52 & 2.35 & 0.070 & 2.52 & \\
\hline BB19 & $\operatorname{tm}$ & 16.5 & 2.19 & 0.132 & 2.52 & 2.19 & 0.133 & 2.52 & \\
\hline BB 18 & $\mathrm{tm}$ & 15.8 & 2.36 & 0.086 & 2.59 & 2.36 & 0.090 & 2.59 & \\
\hline
\end{tabular}


Table 1-2. Busted Butte vertical transect physical properties, dry bulk density, porosity, and particle density calculated using relative-humidity oven and $105^{\circ} \mathrm{C}$ oven-dry weights; saturated hydraulic conductivity and sorptivity calculated from imbibition experiments on relative-humidity-dried samples--Continued

\begin{tabular}{|c|c|c|c|c|c|c|c|c|c|}
\hline \multirow[b]{2}{*}{$\begin{array}{l}\text { Sample } \\
\text { ID }\end{array}$} & \multirow[b]{2}{*}{ Lithology } & \multirow{2}{*}{$\begin{array}{c}\text { Transect } \\
\text { distance } \\
\text { (m) }\end{array}$} & \multicolumn{3}{|c|}{ Relative-humidity oven drlod } & \multicolumn{3}{|c|}{$105^{\circ} \mathrm{C}$ oven dried } & \multirow{2}{*}{$\begin{array}{c}\text { Saturated } \\
\text { hydraulic } \\
\text { conductivity } \\
(\mathrm{m} / \mathrm{s})\end{array}$} \\
\hline & & & $\begin{array}{l}\text { Dry bulk } \\
\text { density } \\
\left(g / \mathrm{cm}^{3}\right)\end{array}$ & $\begin{array}{l}\text { Porosity } \\
\left(\mathrm{cm}^{3} / \mathrm{cm}^{3}\right)\end{array}$ & $\begin{array}{l}\text { Particle } \\
\text { density } \\
\left(g / \mathrm{cm}^{3}\right)\end{array}$ & $\begin{array}{l}\text { Dry bulk } \\
\text { density } \\
\left(\mathrm{g} / \mathrm{cm}^{3}\right)\end{array}$ & $\begin{array}{l}\text { Porosity } \\
\left(\mathrm{cm}^{3} / \mathrm{cm}^{3}\right)\end{array}$ & $\begin{array}{l}\text { Particle } \\
\text { density } \\
\left(\mathrm{g} / \mathrm{cm}^{3}\right)\end{array}$ & \\
\hline BB17 & $\mathrm{tm}$ & 15.5 & 2.38 & 0.074 & 2.58 & 2.38 & 0.077 & 2.58 & \\
\hline BB16 & $\mathrm{tm}$ & 14.6 & 2.37 & 0.073 & 2.55 & 2.36 & 0.074 & 2.55 & \\
\hline BB15 & $\mathrm{tm}$ & 13.7 & 2.37 & 0.069 & 2.55 & 2.37 & 0.074 & 2.55 & \\
\hline BB14 & $\mathrm{tm}$ & 12.8 & 2.31 & 0.101 & 2.57 & 2.30 & 0.103 & 2.57 & \\
\hline BB13A & $\mathrm{tm}$ & 12.2 & 2.34 & 0.092 & 2.58 & 2.34 & 0.096 & 2.59 & \\
\hline BB13 & $\mathrm{tm}$ & 12.2 & 2.34 & 0.063 & 2.50 & 2.34 & 0.063 & 2.50 & \\
\hline BB12 & $\operatorname{tm}$ & 11.6 & 2.33 & 0.096 & 2.58 & 2.33 & 0.096 & 2.58 & \\
\hline BB11 & $\mathrm{tm}$ & 11.0 & 2.21 & 0.101 & 2.46 & 2.21 & 0.104 & 2.47 & \\
\hline BB10 & $\mathrm{tm}$ & 10.4 & 2.39 & 0.078 & 2.59 & 2.38 & 0.080 & 2.59 & \\
\hline BB9 & tv & 9.4 & 2.34 & 0.017 & 2.38 & 2.33 & 0.024 & 2.39 & \\
\hline BB8 & tv & 9.1 & 2.35 & 0.012 & 2.38 & 2.35 & 0.019 & 2.39 & \\
\hline BB7 & tv & 6.1 & 2.35 & 0.012 & 2.37 & 2.34 & 0.018 & 2.38 & \\
\hline BB6 & tv & 4.6 & 2.35 & 0.010 & 2.37 & 2.34 & 0.017 & 2.38 & \\
\hline BB5 & tv & 3.4 & 2.34 & 0.014 & 2.37 & 2.34 & 0.020 & 2.38 & \\
\hline BB4 & tv & 1.8 & 2.28 & 0.014 & 2.31 & 2.27 & 0.021 & 2.32 & \\
\hline BB3 & tv & 0.9 & 2.36 & 0.010 & 2.38 & 2.35 & 0.016 & 2.39 & \\
\hline BB2 & tv & 0.0 & 2.30 & 0.012 & 2.33 & 2.30 & 0.017 & 2.34 & \\
\hline BB1 & tv & 0.0 & 2.35 & 0.014 & 2.38 & 2.34 & 0.017 & 2.38 & \\
\hline
\end{tabular}


Table 1-3. Yucca Wash vertical transect physical properties, dry bulk density, porosity, and particle density calculated using relative-humidity oven and $105^{\circ} \mathrm{C}$ oven-dry weights; saturated hydraulic conductivity and sorptivity calculated from imbibition experiments. Estimates of saturated hydraulic conductivity done using regression equations in table 3.

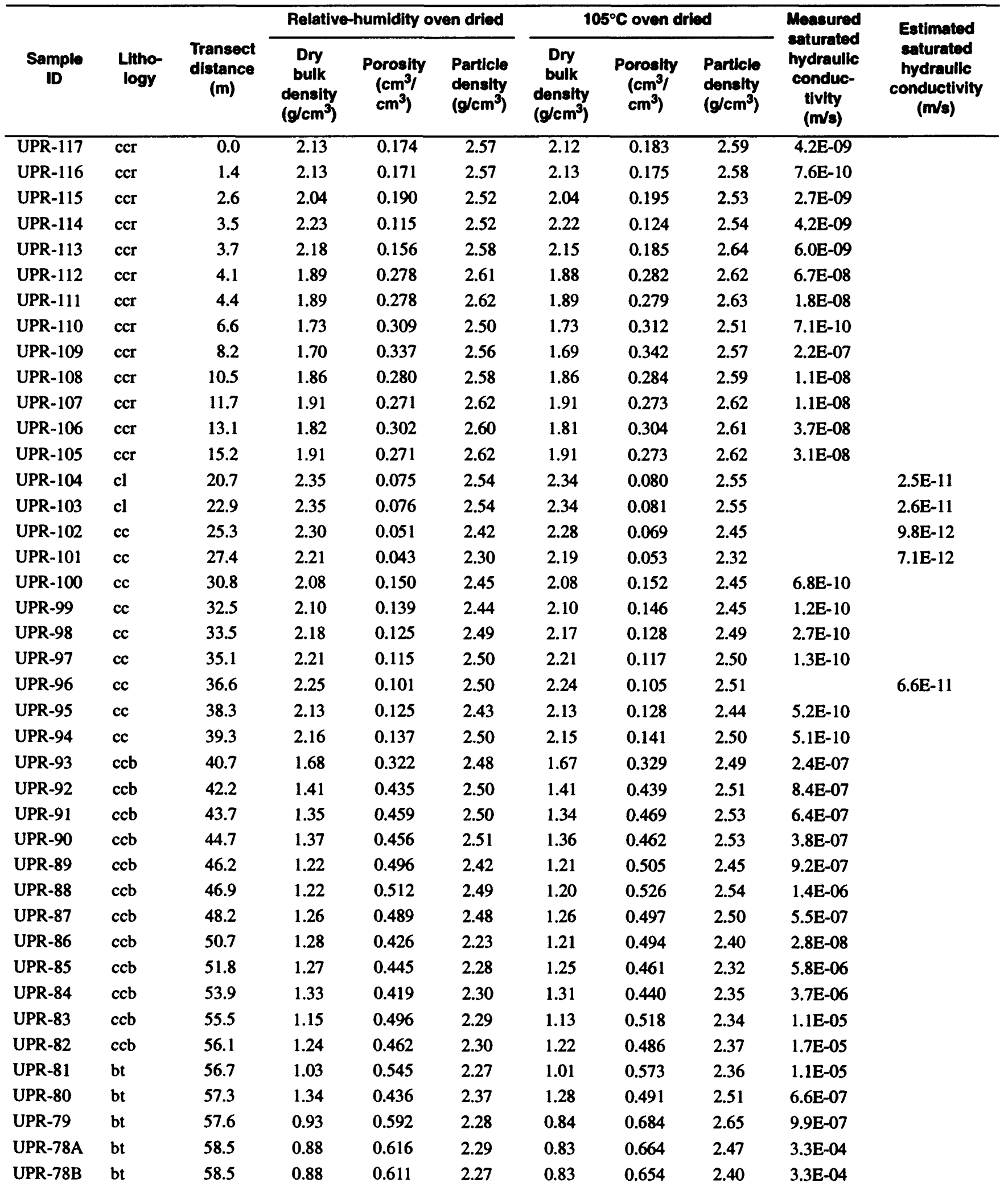


Table 1-3. Yucca Wash vertical transect physical properties, dry bulk density, porosity, and particle density calculated using relative-humidity oven and $105^{\circ} \mathrm{C}$ oven-dry weights; saturated hydraulic conductivity and sorptivity calculated from imbibition experiments. Estimates of saturated hydraulic conductivity done using regression equations in table 3.--Continued

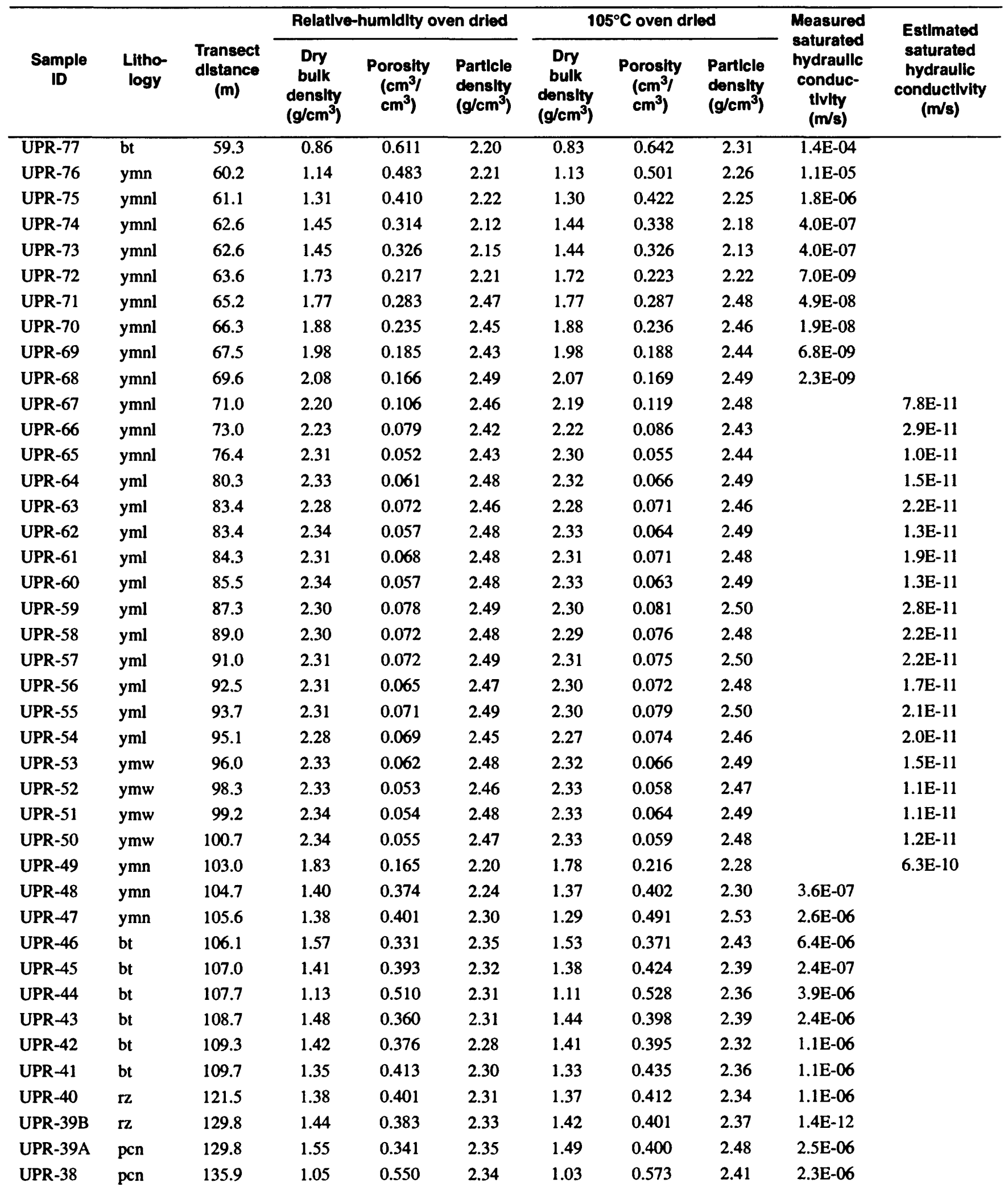


Table 1-3. Yucca Wash vertical transect physical properties, dry bulk density, porosity, and particle density calculated using relative-humidity oven and $105^{\circ} \mathrm{C}$ oven-dry weights; saturated hydraulic conductivity and sorptivity calculated from imbibition experiments. Estimates of saturated hydraulic conductivity done using regression equations in table 3.--Continued

\begin{tabular}{|c|c|c|c|c|c|c|c|c|c|c|}
\hline \multirow[b]{2}{*}{$\begin{array}{c}\text { Sample } \\
\text { ID }\end{array}$} & \multirow[b]{2}{*}{$\begin{array}{l}\text { Litho- } \\
\text { logy }\end{array}$} & \multirow[b]{2}{*}{$\begin{array}{l}\text { Transect } \\
\text { distance } \\
\text { (m) }\end{array}$} & \multicolumn{3}{|c|}{ Relative-humidity oven dried } & \multicolumn{3}{|c|}{$105^{\circ} \mathrm{C}$ oven dried } & \multirow{2}{*}{$\begin{array}{l}\text { Measured } \\
\text { saturated } \\
\text { hydraulic } \\
\text { conduc- } \\
\text { tivity } \\
(\mathrm{m} / \mathrm{s})\end{array}$} & \multirow{2}{*}{$\begin{array}{c}\text { Estimated } \\
\text { saturated } \\
\text { hydraulic } \\
\text { conductivity } \\
(\mathrm{m} / \mathrm{s})\end{array}$} \\
\hline & & & $\begin{array}{c}\text { Dry } \\
\text { bulk } \\
\text { density } \\
\left(\mathbf{g} / \mathrm{cm}^{3}\right)\end{array}$ & $\begin{array}{c}\text { Porosity } \\
\left(\mathrm{cm}^{3}\right) \\
\left.\mathrm{cm}^{3}\right)\end{array}$ & $\begin{array}{l}\text { Particle } \\
\text { density } \\
\left(\mathrm{g} / \mathrm{cm}^{3}\right)\end{array}$ & $\begin{array}{c}\text { Dry } \\
\text { bulk } \\
\text { density } \\
\left(\mathbf{g} / \mathrm{cm}^{3}\right)\end{array}$ & $\begin{array}{c}\text { Porosity } \\
\left(\mathrm{cm}^{3}\right) \\
\left.\mathrm{cm}^{3}\right)\end{array}$ & $\begin{array}{l}\text { Particle } \\
\text { denslty } \\
\left(\mathrm{g} / \mathrm{cm}^{3}\right)\end{array}$ & & \\
\hline UPR-37 & pen & 138.4 & 1.17 & 0.504 & 2.35 & 1.14 & 0.528 & 2.42 & $1.8 \mathrm{E}-06$ & \\
\hline UPR-36 & pen & 140.5 & 1.16 & 0.504 & 2.34 & 1.11 & 0.557 & 2.51 & $1.9 \mathrm{E}-06$ & \\
\hline UPR-35 & pen & 142.3 & 1.18 & 0.498 & 2.34 & 1.15 & 0.523 & 2.41 & $2.5 \mathrm{E}-06$ & \\
\hline UPR-34 & pen & 144.3 & 1.22 & 0.480 & 2.34 & 1.19 & 0.505 & 2.41 & 9.5E-07 & \\
\hline UPR-33 & pen & 145.5 & 1.24 & 0.474 & 2.35 & 1.19 & 0.521 & 2.48 & $3.8 \mathrm{E}-07$ & \\
\hline UPR-32 & pen & 147.4 & 1.24 & 0.468 & 2.34 & 1.22 & 0.491 & 2.40 & $2.0 \mathrm{E}-07$ & \\
\hline UPR-31 & pen & 149.5 & 1.20 & 0.485 & 2.33 & 1.18 & 0.505 & 2.38 & $2.4 \mathrm{E}-07$ & \\
\hline UPR-30 & pen & 151.0 & 1.15 & 0.503 & 2.32 & 1.13 & 0.531 & 2.40 & 5.3E-07 & \\
\hline UPR-29 & pen & 152.6 & 1.30 & 0.433 & 2.30 & 1.27 & 0.462 & 2.37 & $6.3 \mathrm{E}-09$ & \\
\hline UPR-28 & pen & 154.4 & 1.51 & 0.379 & 2.42 & 1.49 & 0.394 & 2.46 & $6.3 \mathrm{E}-09$ & \\
\hline UPR-27 & pcpw & 156.1 & 1.53 & 0.389 & 2.50 & 1.52 & 0.398 & 2.53 & 2.1E-07 & \\
\hline UPR-26 & pcpw & 157.9 & 1.66 & 0.341 & 2.52 & 1.65 & 0.354 & 2.55 & $3.1 \mathrm{E}-08$ & \\
\hline UPR-25 & pcpw & 160.0 & 1.73 & 0.313 & 2.51 & 1.72 & 0.322 & 2.53 & 3.2E-08 & \\
\hline UPR-24 & pcpw & 162.9 & 1.90 & 0.240 & 2.50 & 1.89 & 0.250 & 2.52 & 3.9E-09 & \\
\hline UPR-23 & pcpw & 164.3 & 2.03 & 0.196 & 2.52 & 2.01 & 0.210 & 2.55 & & $7.3 \mathrm{E}-11$ \\
\hline UPR-22 & pcpw & 165.8 & 1.93 & 0.235 & 2.52 & 1.92 & 0.242 & 2.54 & 1.7E-08 & \\
\hline UPR-21 & pcpw & 167.3 & 1.85 & 0.270 & 2.54 & 1.85 & 0.275 & 2.55 & $2.6 \mathrm{E}-08$ & \\
\hline UPR-20 & pcpw & 169.5 & 1.88 & 0.256 & 2.53 & 1.86 & 0.272 & 2.56 & $1.9 \mathrm{E}-09$ & \\
\hline UPR-19 & pcpw & 170.5 & 1.83 & 0.272 & 2.51 & 1.81 & 0.291 & 2.55 & 7.5E-09 & \\
\hline UPR-18 & pcpw & 172.2 & 1.83 & 0.265 & 2.49 & 1.80 & 0.290 & 2.54 & $8.0 \mathrm{E}-09$ & \\
\hline UPR-17 & pcpw & 173.1 & 1.92 & 0.232 & 2.50 & 1.88 & 0.267 & 2.57 & $1.9 \mathrm{E}-09$ & \\
\hline UPR-16 & pcpw & 174.0 & 1.90 & 0.240 & 2.49 & 1.86 & 0.272 & 2.56 & $1.2 \mathrm{E}-09$ & \\
\hline UPR-15 & pcpw & 180.4 & 2.17 & 0.123 & 2.48 & 2.11 & 0.182 & 2.59 & $7.0 \mathrm{E}-11$ & \\
\hline UPR-14 & pcpw & 185.2 & 1.90 & 0.265 & 2.58 & 1.89 & 0.279 & 2.62 & 2.1E-09 & \\
\hline UPR-13 & pcpw & 187.6 & 1.94 & 0.225 & 2.50 & 1.93 & 0.234 & 2.52 & 2.9E-10 & \\
\hline UPR-12 & pcpw & 188.7 & 1.97 & 0.201 & 2.47 & 1.93 & 0.237 & 2.54 & $6.0 \mathrm{E}-11$ & \\
\hline UPR-11 & pcpw & 190.0 & 1.81 & 0.239 & 2.38 & 1.76 & 0.297 & 2.50 & $1.2 \mathrm{E}-10$ & \\
\hline UPR-10 & pen & 193.2 & 1.58 & 0.288 & 2.22 & 1.49 & 0.372 & 2.38 & $1.5 \mathrm{E}-10$ & \\
\hline UPR-9 & pen & 199.0 & 1.60 & 0.266 & 2.17 & 1.50 & 0.357 & 2.34 & $5.0 \mathrm{E}-11$ & \\
\hline UPR-8 & pen & 200.4 & 1.63 & 0.237 & 2.13 & 1.53 & 0.334 & 2.30 & $1.0 \mathrm{E}-10$ & \\
\hline UPR-7 & pen & 201.9 & 1.41 & 0.367 & 2.24 & 1.33 & 0.455 & 2.43 & $1.4 \mathrm{E}-09$ & \\
\hline UPR-6 & pen & 203.5 & 1.39 & 0.382 & 2.25 & 1.31 & 0.463 & 2.44 & $6.6 \mathrm{E}-10$ & \\
\hline UPR-5 & pen & 210.2 & 1.31 & 0.414 & 2.24 & 1.23 & 0.494 & 2.44 & & $1.1 \mathrm{E}-09$ \\
\hline UPR-4 & tn & 210.8 & 1.41 & 0.365 & 2.23 & 1.33 & 0.448 & 2.41 & $3.4 \mathrm{E}-06$ & \\
\hline UPR-3 & tn & 211.7 & 1.66 & 0.359 & 2.59 & 1.64 & 0.376 & 2.64 & $6.9 \mathrm{E}-07$ & \\
\hline UPR-2 & tc & 212.8 & 2.30 & 0.026 & 2.36 & 2.38 & 0.033 & 2.46 & & $1.5 \mathrm{E}-10$ \\
\hline UPR-1 & tc & 212.4 & 2.40 & 0.013 & 2.43 & 2.46 & 0.021 & 2.51 & & $2.9 \mathrm{E}-10$ \\
\hline CRT-7 & tn & 212.0 & 1.66 & 0.230 & 2.16 & 1.58 & 0.316 & 2.31 & $1.0 \mathrm{E}-07$ & \\
\hline CRT-6 & tn & 212.1 & 1.68 & 0.233 & 2.19 & 1.61 & 0.310 & 2.33 & $2.9 \mathrm{E}-08$ & \\
\hline CRT-5 & tn & 212.1 & 1.93 & 0.139 & 2.24 & 1.83 & 0.237 & 2.40 & $4.8 \mathrm{E}-11$ & \\
\hline CRT-3 & tc & 213.1 & 2.41 & 0.007 & 2.43 & 2.40 & 0.021 & 2.45 & & 4.4E-10 \\
\hline
\end{tabular}


Table 1-3. Yucca Wash vertical transect physical properties, dry bulk density, porosity, and particle density calculated using relative-humidity oven and $105^{\circ} \mathrm{C}$ oven-dry weights; saturated hydraulic conductivity and sorptivity calculated from imbibition experiments. Estimates of saturated hydraulic conductivity done using regression equations in table 3.--Continued

\begin{tabular}{|c|c|c|c|c|c|c|c|c|c|c|}
\hline \multirow[b]{2}{*}{$\begin{array}{l}\text { Sample } \\
\text { ID }\end{array}$} & \multirow[b]{2}{*}{$\begin{array}{l}\text { Litho- } \\
\text { logy }\end{array}$} & \multirow[b]{2}{*}{$\begin{array}{l}\text { Transect } \\
\text { dlstance } \\
\text { (m) }\end{array}$} & \multicolumn{3}{|c|}{ Relatlve-humldity oven dried } & \multicolumn{3}{|c|}{$105^{\circ} \mathrm{C}$ oven dried } & \multirow{2}{*}{$\begin{array}{l}\text { Measured } \\
\text { saturated } \\
\text { hydraulic } \\
\text { conduc- } \\
\text { tivity } \\
(\mathrm{m} / \mathrm{s})\end{array}$} & \multirow{2}{*}{$\begin{array}{c}\text { Estlmated } \\
\text { saturated } \\
\text { hydraullic } \\
\text { conductlvity } \\
(\mathrm{m} / \mathrm{s})\end{array}$} \\
\hline & & & $\begin{array}{c}\text { Dry } \\
\text { bulk } \\
\text { density } \\
\left(\mathrm{g} / \mathrm{cm}^{3}\right)\end{array}$ & $\begin{array}{l}\text { Porosity } \\
\left(\mathrm{cm}^{3}{ }^{3}\right. \\
\left.\mathrm{cm}^{3}\right)\end{array}$ & $\begin{array}{l}\text { Partlcle } \\
\text { density } \\
\left(\mathrm{g} / \mathrm{cm}^{3}\right)\end{array}$ & $\begin{array}{c}\text { Dry } \\
\text { bulk } \\
\text { donstyy } \\
\left(g / \mathrm{cm}^{3}\right)\end{array}$ & $\begin{array}{c}\text { Porosity } \\
\left(\mathrm{cm}^{3} /\right. \\
\left.\mathrm{cm}^{3}\right)\end{array}$ & $\begin{array}{l}\text { Particle } \\
\text { density } \\
\left(\mathrm{g} / \mathrm{cm}^{3}\right)\end{array}$ & & \\
\hline CRT-2 & tc & 213.1 & 2.43 & 0.066 & 2.60 & 2.43 & 0.070 & 2.61 & & $2.6 \mathrm{E}-10$ \\
\hline CRT-1 & tc & 216.6 & 2.36 & 0.075 & 2.55 & 2.36 & 0.079 & 2.56 & $5.3 \mathrm{E}-10$ & \\
\hline LPR-32 & tc & 216.6 & 2.49 & 0.013 & 2.53 & 2.49 & 0.017 & 2.53 & $3.8 \mathrm{E}-09$ & \\
\hline LPR-31 & tc & 217.0 & 2.39 & 0.069 & 2.57 & 2.39 & 0.074 & 2.58 & & $3.2 \mathrm{E}-10$ \\
\hline LPR-30 & tr & 219.5 & 2.30 & 0.082 & 2.50 & 2.29 & 0.086 & 2.51 & $4.0 \mathrm{E}-10$ & \\
\hline LPR-29 & $\mathbf{t r}$ & 222.4 & 2.32 & 0.089 & 2.54 & 2.31 & 0.092 & 2.55 & 4.1E-09 & \\
\hline LPR-28 & tr & 224.6 & 2.32 & 0.05 & 2.45 & 2.31 & 0.09 & 2.54 & & 9.5E-12 \\
\hline LPR-27 & tul & 227.7 & 2.1 & 0.15 & 2.47 & 2.09 & 0.19 & 2.58 & & $3.8 \mathrm{E}-10$ \\
\hline LPR-26 & tul & 231.6 & 2.29 & 0.078 & 2.48 & 2.28 & 0.081 & 2.48 & & $2.8 \mathrm{E}-11$ \\
\hline LPR-25 & $\operatorname{tmn}$ & 233.3 & 2.24 & 0.099 & 2.48 & 2.22 & 0.112 & 2.51 & 7.7E-11 & \\
\hline LPR-24 & $\mathrm{tmn}$ & 236.4 & 2.26 & 0.089 & 2.50 & 2.24 & 0.107 & 2.51 & $2.8 \mathrm{E}-12$ & \\
\hline LPR-23 & $\operatorname{tmn}$ & 237.9 & 2.24 & 0.099 & 2.48 & 2.23 & 0.105 & 2.49 & $1.0 \mathrm{E}-12$ & \\
\hline LPR-22 & $\operatorname{tmn}$ & 239.7 & 2.26 & 0.089 & 2.48 & 2.26 & 0.091 & 2.49 & & 4.2E-11 \\
\hline LPR-21 & tll & 241.6 & 2.23 & 0.080 & 2.43 & 2.21 & 0.102 & 2.46 & & $3.1 \mathrm{E}-11$ \\
\hline LPR-19 & tll & 247.3 & 2.31 & 0.067 & 2.47 & $2: 30$ & 0.070 & 2.48 & & $1.9 \mathrm{E}-11$ \\
\hline LPR-18 & tll & 248.9 & 2.32 & 0.062 & 2.47 & 2.32 & 0.066 & 2.48 & & $1.5 \mathrm{E}-11$ \\
\hline LPR-17 & tll & 251.5 & 2.38 & 0.044 & 2.49 & 2.37 & 0.056 & 2.51 & & 7.5E-12 \\
\hline LPR-16 & tll & 254.1 & 2.40 & 0.028 & 2.47 & 2.40 & 0.035 & 2.48 & & $4.0 \mathrm{E}-12$ \\
\hline LPR-15 & tv & 256.8 & 2.42 & 0.023 & 2.48 & 2.41 & 0.032 & 2.49 & $1.4 \mathrm{E}-10$ & \\
\hline LPR-10 & tv & 267.0 & 2.34 & 0.011 & 2.37 & 2.33 & 0.019 & 2.38 & $3.5 \mathrm{E}-11$ & \\
\hline LPR-7 & tv & 273.3 & 2.16 & 0.055 & 2.29 & 2.12 & 0.099 & 2.35 & $2.1 \mathrm{E}-10$ & \\
\hline LPR-6A & Tht & 276.3 & 1.60 & 0.232 & 2.08 & 1.53 & 0.314 & 2.23 & $7.0 \mathrm{E}-11$ & \\
\hline LPR-6B & Tht & 276.3 & 1.64 & 0.204 & 2.06 & 1.52 & 0.313 & 2.21 & $3.5 \mathrm{E}-10$ & \\
\hline LPR-5 & Tht & 279.8 & 1.62 & 0.204 & 2.04 & 1.53 & 0.299 & 2.18 & & $3.9 \mathrm{E}-10$ \\
\hline LPR-4 & Tht & 284.4 & 1.53 & 0.320 & 2.25 & 1.45 & 0.397 & 2.41 & & $3.0 \mathrm{E}-10$ \\
\hline LPR-3B & Tht & 286.8 & 1.50 & 0.301 & 2.15 & 1.40 & 0.359 & 2.18 & $1.0 \mathrm{E}-10$ & \\
\hline LPR-3A & Tht & 286.8 & 1.45 & 0.304 & 2.09 & 1.43 & 0.378 & 2.29 & $6.5 \mathrm{E}-11$ & \\
\hline LPR-2 & Tht & 288.6 & 1.48 & 0.319 & 2.17 & 1.40 & 0.398 & 2.33 & 3.7E-10 & \\
\hline LPR-1 & Tht & 290.2 & 1.42 & 0.306 & 2.05 & 1.34 & 0.387 & 2.19 & $7.1 \mathrm{E}-11$ & \\
\hline
\end{tabular}


Table 1-4. Pagany Wash vertical transect physical properties, dry bulk density, porosity, and particle density calculated using relative-humidity oven and $105^{\circ} \mathrm{C}$ oven-dry weights; saturated hydraulic conductivity and sorptivity caiculated from imbibition experiments on reiative-humidity-dried samples

\begin{tabular}{|c|c|c|c|c|c|c|c|c|c|}
\hline \multirow[b]{2}{*}{$\begin{array}{c}\text { Sample } \\
\text { ID }\end{array}$} & \multirow[b]{2}{*}{ Lithology } & \multirow{2}{*}{$\begin{array}{c}\text { Transect } \\
\text { distance } \\
\text { (m) }\end{array}$} & \multicolumn{3}{|c|}{ Relative-humidity oven driod } & \multicolumn{3}{|c|}{$105^{\circ} \mathrm{C}$ oven dried } & \multirow{2}{*}{$\begin{array}{l}\text { Saturated } \\
\text { hydraulic } \\
\text { conductivity } \\
(\mathrm{m} / \mathrm{s})\end{array}$} \\
\hline & & & $\begin{array}{l}\text { Dry bulk } \\
\text { density } \\
\left(g / \mathrm{cm}^{3}\right)\end{array}$ & $\begin{array}{l}\text { Porosity } \\
\left(\mathrm{cm}^{3} / \mathrm{cm}^{3}\right)\end{array}$ & $\begin{array}{l}\text { Particle } \\
\text { donsilty } \\
\left(g / \mathrm{cm}^{3}\right)\end{array}$ & $\begin{array}{l}\text { Dry bulk } \\
\text { density } \\
\left(g / \mathrm{cm}^{3}\right)\end{array}$ & $\begin{array}{l}\text { Porosity } \\
\left(\mathrm{cm}^{3} / \mathrm{cm}^{3}\right)\end{array}$ & $\begin{array}{l}\text { Particle } \\
\text { density } \\
\left(g / \mathrm{cm}^{3}\right)\end{array}$ & \\
\hline PW20 & cer & 0.0 & 2.30 & 0.091 & 2.53 & 2.30 & 0.092 & 2.53 & $1.2 \mathrm{E}-09$ \\
\hline PW19 & ccr & 0.0 & 2.29 & 0.095 & 2.54 & 2.29 & 0.097 & 2.54 & \\
\hline PW18 & ccr & 0.2 & 2.16 & 0.155 & 2.56 & 2.16 & 0.156 & 2.56 & $3.9 \mathrm{E}-09$ \\
\hline PW17 & ccr & 1.5 & 2.27 & 0.108 & 2.55 & 2.27 & 0.109 & 2.55 & \\
\hline PW16 & cer & 2.1 & 2.20 & 0.128 & 2.52 & 2.20 & 0.129 & 2.52 & \\
\hline PW15 & ccr & 3.0 & 2.18 & 0.132 & 2.51 & 2.18 & 0.134 & 2.52 & \\
\hline PW14 & ccr & 5.8 & 1.93 & 0.238 & 2.53 & 1.93 & 0.239 & 2.53 & \\
\hline PW13 & ccr & 7.6 & 1.92 & 0.243 & 2.53 & 1.91 & 0.246 & 2.54 & \\
\hline PW12 & ccr & 9.4 & 1.93 & 0.245 & 2.55 & 1.92 & 0.246 & 2.55 & \\
\hline PW11 & cer & 11.0 & 1.82 & 0.290 & 2.56 & 1.82 & 0.291 & 2.56 & \\
\hline PW10 & ccr & 11.9 & 1.86 & 0.278 & 2.58 & 1.86 & 0.280 & 2.58 & \\
\hline PW9 & ccr & 13.4 & 1.89 & 0.267 & 2.57 & 1.88 & 0.269 & 2.58 & \\
\hline PW8 & ccr & 15.2 & 1.81 & 0.287 & 2.54 & 1.81 & 0.288 & 2.55 & \\
\hline PW7 & ccr & 16.9 & 1.89 & 0.264 & 2.57 & 1.89 & 0.265 & 2.57 & \\
\hline PW6 & cuc & 18.6 & 2.07 & 0.187 & 2.54 & 2.07 & 0.187 & 2.55 & \\
\hline PW5 & cuc & 19.5 & 1.97 & 0.227 & 2.55 & 1.97 & 0.228 & 2.55 & \\
\hline PW4 & cuc & 21.0 & 2.05 & 0.197 & 2.55 & 2.05 & 0.198 & 2.55 & \\
\hline PW3 & cuc & 22.1 & 2.03 & 0.198 & 2.53 & 2.03 & 0.199 & 2.53 & \\
\hline PW2 & cul & 23.5 & 2.13 & 0.156 & 2.52 & 2.13 & 0.157 & 2.52 & \\
\hline PW1 & cul & 25.0 & 2.13 & 0.157 & 2.52 & 2.12 & 0.159 & 2.52 & \\
\hline
\end{tabular}


Table 1-5. Calico Hills Formation vertical transect physical properties, dry bulk density, porosity, and particle density calculated using relative humidity oven and $105^{\circ} \mathrm{C}$ oven-dry weights; saturated hydraulic conductivity and sorptivity calculated from imbibition experiments on relative-humidity-dried samples

\begin{tabular}{|c|c|c|c|c|c|c|c|c|c|c|}
\hline \multirow[b]{2}{*}{$\begin{array}{l}\text { Sample } \\
\text { ID }\end{array}$} & \multirow[b]{2}{*}{$\begin{array}{l}\text { Litho- } \\
\text { logy }\end{array}$} & \multirow[b]{2}{*}{$\begin{array}{c}\text { Transect } \\
\text { distance } \\
\text { (m) }\end{array}$} & \multicolumn{3}{|c|}{ Relative-humidity oven dried } & \multicolumn{3}{|c|}{$105^{\circ} \mathrm{C}$ oven dried } & \multirow{2}{*}{$\begin{array}{c}\text { Saturated } \\
\text { hydraulic } \\
\text { conduc- } \\
\text { tivity } \\
(\mathrm{m} / \mathrm{s})\end{array}$} & \multirow[b]{2}{*}{$\begin{array}{c}\text { RH-dried } \\
\text { sorptivity } \\
\left(\mathrm{m} / \mathrm{s}^{0.5}\right)\end{array}$} \\
\hline & & & $\begin{array}{c}\text { Dry } \\
\text { bulk } \\
\text { density } \\
\left(\mathrm{g} / \mathrm{cm}^{3}\right)\end{array}$ & $\begin{array}{l}\text { Porosity } \\
\left(\mathrm{cm}^{3} \mathbf{3}\right. \\
\left.\mathrm{cm}^{3}\right)\end{array}$ & $\begin{array}{l}\text { Partlcle } \\
\text { density } \\
\left(\mathbf{g} / \mathrm{cm}^{3}\right)\end{array}$ & $\begin{array}{l}\text { Dry bulk } \\
\text { density } \\
\left(\mathrm{g} / \mathrm{cm}^{3}\right)\end{array}$ & $\begin{array}{l}\text { Porosity } \\
\left(\mathrm{cm}^{3} \mathbf{3}\right. \\
\left.\mathrm{cm}^{3}\right)\end{array}$ & $\begin{array}{l}\text { Particle } \\
\text { density } \\
\left(\mathrm{g} / \mathrm{cm}^{3}\right)\end{array}$ & & \\
\hline$\overline{\mathrm{CH} 64}$ & Thtz & 0.0 & 2.11 & 0.104 & 2.35 & 2.09 & 0.126 & 2.39 & & \\
\hline $\mathrm{CH} 63$ & Thtz & 1.8 & 1.94 & 0.137 & 2.25 & 1.87 & 0.201 & 2.34 & & \\
\hline CH62 & Thtz & 2.7 & 1.99 & 0.083 & 2.17 & 1.89 & 0.178 & 2.30 & & \\
\hline $\mathrm{CH} 61$ & Thtz & 4.6 & $1.80^{\circ}$ & 0.158 & 2.14 & 1.71 & 0.249 & 2.28 & & \\
\hline CH59G & Thtz & 7.9 & 1.61 & 0.215 & 2.05 & 1.52 & 0.302 & 2.18 & & \\
\hline CH59R* & Thtz & 7.9 & 1.60 & 0.231 & 2.08 & 1.51 & 0.317 & 2.21 & & \\
\hline CH58 & Thtz & 9.3 & 1.71 & 0.181 & 2.09 & 1.62 & 0.269 & 2.22 & & \\
\hline CH57 & Thtz & 10.7 & 1.51 & 0.285 & 2.11 & 1.43 & 0.366 & 2.25 & & \\
\hline CH56 & Thtz & 11.9 & 1.68 & 0.215 & 2.14 & 1.59 & 0.300 & 2.28 & & \\
\hline CH55 & Thtz & 13.6 & 1.62 & 0.263 & 2.20 & 1.53 & 0.351 & 2.36 & & \\
\hline CH54 & Thtz & 15.1 & 1.42 & 0.308 & 2.05 & 1.35 & 0.380 & 2.17 & & \\
\hline CH53 & Thtz & 16.9 & 1.56 & 0.278 & 2.15 & 1.47 & 0.360 & 2.30 & & \\
\hline CH52 & Thtz & 18.3 & 1.59 & 0.267 & 2.16 & 1.50 & 0.353 & 2.32 & & \\
\hline $\mathrm{CH} 51$ & Thtz & 19.8 & 1.66 & 0.254 & 2.23 & 1.59 & 0.324 & 2.36 & & \\
\hline $\mathrm{CH} 50$ & Thtz & 22.3 & 1.60 & 0.278 & 2.22 & 1.52 & 0.355 & 2.36 & & \\
\hline $\mathrm{CH} 49$ & Thtz & 23.8 & 1.71 & 0.230 & 2.22 & 1.63 & 0.314 & 2.37 & & \\
\hline $\mathrm{CH} 48$ & Thtz & 25.0 & 1.74 & 0.217 & 2.23 & 1.66 & 0.304 & 2.38 & & \\
\hline $\mathrm{CH} 47$ & Thtz & 26.4 & 1.72 & 0.231 & 2.23 & 1.63 & 0.313 & 2.38 & $2.9 \mathrm{E}-11$ & \\
\hline $\mathrm{CH} 46$ & Thtz & 27.9 & 1.77 & 0.203 & 2.22 & 1.69 & 0.286 & 2.37 & & \\
\hline $\mathrm{CH} 45$ & Thtz & 29.6 & 1.74 & 0.216 & 2.22 & 1.65 & 0.300 & 2.36 & & \\
\hline $\mathrm{CH} 44$ & Thtz & 30.8 & 1.67 & 0.223 & 2.15 & 1.59 & 0.302 & 2.28 & $8.4 \mathrm{E}-11$ & \\
\hline $\mathrm{CH} 43$ & Thtz & 32.3 & 1.54 & 0.303 & 2.21 & 1.46 & 0.380 & 2.36 & & \\
\hline $\mathrm{CH} 42$ & Thtz & 33.5 & 1.62 & 0.260 & 2.19 & 1.55 & 0.334 & 2.33 & & \\
\hline $\mathrm{CH} 4 \mathrm{I}$ & Thtz & 34.9 & 1.58 & 0.291 & 2.22 & 1.51 & 0.362 & 2.36 & & \\
\hline $\mathrm{CH} 40$ & Thtz & 36.4 & 1.56 & 0.294 & 2.21 & 1.50 & 0.354 & 2.32 & $2.1 \mathrm{E}-10$ & \\
\hline CH39 & Thtz & 37.9 & 1.63 & 0.277 & 2.26 & 1.58 & 0.332 & 2.36 & & \\
\hline $\mathrm{CH} 38$ & Thtz & 39.3 & 1.61 & 0.280 & 2.23 & 1.54 & 0.341 & 2.34 & & \\
\hline $\mathrm{CH} 37$ & Thtz & 40.8 & 1.75 & 0.213 & 2.22 & 1.66 & 0.301 & 2.37 & & \\
\hline $\mathrm{CH} 36$ & Thtz & 42.4 & 1.77 & 0.213 & 2.25 & 1.69 & 0.294 & 2.39 & & \\
\hline CH35 & Thtz & 43.9 & 1.72 & 0.223 & 2.21 & 1.64 & 0.301 & 2.34 & & \\
\hline $\mathrm{CH} 34$ & Thtz & 44.8 & 1.73 & 0.218 & 2.22 & 1.65 & 0.298 & 2.36 & & \\
\hline CH35A & Thtz & 44.8 & 1.76 & 0.217 & 2.25 & 1.66 & 0.311 & 2.41 & & \\
\hline CH33 & Thtz & 46.5 & 1.78 & 0.211 & 2.25 & 1.70 & 0.291 & 2.39 & $4.6 \mathrm{E}-12$ & \\
\hline $\mathrm{CH} 32$ & Thtz & 48.0 & 1.72 & 0.229 & 2.24 & 1.65 & 0.308 & 2.38 & & $1.4 \mathrm{E}-05$ \\
\hline $\mathrm{CH} 31 \mathrm{~B}$ & Thtz & 49.7 & 1.65 & 0.255 & 2.22 & 1.58 & 0.329 & 2.35 & & \\
\hline $\mathrm{CH} 31 \mathrm{~A}$ & Thtz & 49.7 & 1.78 & 0.211 & 2.25 & 1.71 & 0.281 & 2.38 & & \\
\hline $\mathrm{CH} 30$ & Thtz & 51.2 & 1.84 & 0.206 & 2.32 & 1.80 & 0.251 & 2.40 & & \\
\hline $\mathrm{CH} 29$ & Thtz & 52.7 & 1.58 & 0.275 & 2.18 & 1.53 & 0.332 & 2.29 & & \\
\hline $\mathrm{CH} 28$ & Thtz & 55.5 & 1.39 & 0.371 & 2.22 & 1.34 & 0.425 & 2.33 & & \\
\hline $\mathrm{CH} 27$ & Thtz & 57.8 & 1.50 & 0.305 & 2.16 & 1.44 & 0.362 & 2.26 & & \\
\hline $\mathrm{CH} 26$ & Thtz & 59.1 & 1.54 & 0.281 & 2.13 & 1.48 & 0.339 & 2.23 & & \\
\hline $\mathrm{CH} 25$ & Thtz & 60.4 & 1.49 & 0.302 & 2.14 & 1.43 & 0.359 & 2.24 & & 3.1E-05 \\
\hline
\end{tabular}


Table 1-5. Calico Hills Formation vertical transect physical properties, dry bulk density, porosity, and particle density calculated using relative humidity oven and $105^{\circ} \mathrm{C}$ oven-dry weights; saturated hydraulic conductivity and sorptivity calculated from imbibition experiments on relative-humidity-dried samples--Continued

\begin{tabular}{|c|c|c|c|c|c|c|c|c|c|c|}
\hline \multirow[b]{2}{*}{$\begin{array}{l}\text { Sample } \\
\text { ID }\end{array}$} & \multirow[b]{2}{*}{$\begin{array}{l}\text { Litho- } \\
\text { logy }\end{array}$} & \multirow[b]{2}{*}{$\begin{array}{l}\text { Transect } \\
\text { distance } \\
\text { (m) }\end{array}$} & \multicolumn{3}{|c|}{ Relative-humidity oven dried } & \multicolumn{3}{|c|}{$105^{\circ} \mathrm{C}$ oven dried } & \multirow{2}{*}{$\begin{array}{l}\text { Saturated } \\
\text { hydraulic } \\
\text { conduc- } \\
\text { tivity } \\
(\mathbf{m} / \mathbf{s})\end{array}$} & \multirow[b]{2}{*}{$\begin{array}{c}\text { RH-dried } \\
\text { sorptivity } \\
\left(\mathrm{m} / \mathrm{s}^{0.5}\right)\end{array}$} \\
\hline & & & $\begin{array}{c}\text { Dry } \\
\text { bulk } \\
\text { density } \\
\left(\mathrm{g} / \mathrm{cm}^{3}\right)\end{array}$ & $\begin{array}{l}\text { Porosity } \\
\left(\mathrm{cm}^{3} /\right. \\
\left.\mathrm{cm}^{3}\right)\end{array}$ & $\begin{array}{l}\text { Particle } \\
\text { density } \\
\left(\mathrm{g} / \mathrm{cm}^{3}\right)\end{array}$ & $\begin{array}{l}\text { Dry bulk } \\
\text { density } \\
\left(\mathrm{g} / \mathrm{cm}^{3}\right)\end{array}$ & $\begin{array}{l}\text { Porosity } \\
\left(\mathrm{cm}^{3} /\right. \\
\left.\mathrm{cm}^{3}\right)\end{array}$ & $\begin{array}{l}\text { Particle } \\
\text { denslty } \\
\left(\mathrm{g} / \mathrm{cm}^{3}\right)\end{array}$ & & \\
\hline $\mathrm{CH} 24$ & Thtz & 61.6 & 1.48 & 0.307 & 2.14 & 1.42 & 0.370 & 2.25 & & \\
\hline $\mathrm{CH} 23$ & Thtz & 63.1 & 1.42 & 0.327 & 2.10 & 1.35 & 0.392 & 2.22 & & \\
\hline $\mathrm{CH} 22$ & Thtz & 64.9 & 1.54 & 0.305 & 2.22 & 1.48 & 0.368 & 2.34 & & \\
\hline $\mathrm{CH} 21$ & Thtz & 65.8 & 1.43 & 0.317 & 2.10 & 1.38 & 0.374 & 2.20 & & $1.4 \mathrm{E}-05$ \\
\hline $\mathrm{CH} 20$ & Thtz & 66.8 & 1.42 & 0.356 & 2.20 & 1.36 & 0.413 & 2.31 & & \\
\hline $\mathrm{CH} 19$ & Thtz & 68.0 & 1.37 & 0.382 & 2.22 & 1.32 & 0.432 & 2.32 & & \\
\hline $\mathrm{CH} 18$ & Thtz & 69.6 & 1.43 & 0.314 & 2.09 & 1.37 & 0.375 & 2.19 & & 2.1E-05 \\
\hline $\mathrm{CH} 17$ & Thtz & 71.0 & 1.52 & 0.301 & 2.17 & 1.46 & 0.362 & 2.28 & & \\
\hline $\mathrm{CH} 16$ & Thtz & 72.5 & 1.56 & 0.293 & 2.21 & 1.50 & 0.356 & 2.33 & & \\
\hline $\mathrm{CH} 15$ & Thtz & 74.2 & 1.50 & 0.304 & 2.15 & 1.44 & 0.365 & 2.26 & & \\
\hline $\mathrm{CH} 14$ & Thtz & 75.6 & 1.44 & 0.371 & 2.29 & 1.38 & 0.430 & 2.42 & & \\
\hline $\mathrm{CH} 13$ & Thtz & 75.7 & 1.57 & 0.293 & 2.22 & 1.51 & 0.357 & 2.34 & & \\
\hline $\mathrm{CH} 12$ & Thtz & 77.1 & 1.75 & 0.222 & 2.25 & 1.69 & 0.287 & 2.37 & & \\
\hline $\mathrm{CH} 11$ & Thtz & 78.6 & 1.54 & 0.312 & 2.23 & 1.48 & 0.371 & 2.35 & & \\
\hline $\mathrm{CH} 10$ & Thtz & 80.2 & 1.47 & 0.339 & 2.23 & 1.42 & 0.392 & 2.34 & & \\
\hline CH9 & Thtz & 81.4 & 1.50 & 0.323 & 2.21 & 1.44 & 0.381 & 2.33 & & \\
\hline $\mathrm{CH} 8$ & Thtz & 83.8 & 1.55 & 0.303 & 2.22 & 1.49 & 0.362 & 2.34 & & \\
\hline $\mathrm{CH} 7$ & Thtz & 86.0 & 1.61 & 0.304 & 2.31 & 1.55 & 0.363 & 2.44 & & \\
\hline $\mathrm{CH} 6$ & Thtz & 87.5 & 1.67 & 0.257 & 2.25 & 1.61 & 0.317 & 2.36 & & \\
\hline CH5 & Thtz & 89.0 & 1.62 & 0.296 & 2.30 & 1.57 & 0.347 & 2.41 & & \\
\hline $\mathrm{CH} 4$ & Thtz & 93.6 & 1.93 & 0.189 & 2.38 & 1.88 & 0.239 & 2.47 & $1.1 \mathrm{E}-10$ & $1.2 \mathrm{E}-05$ \\
\hline $\mathrm{CH} 3$ & Thtz & 94.8 & 1.90 & 0.203 & 2.38 & 1.86 & 0.241 & 2.45 & & \\
\hline $\mathrm{CH} 2$ & $\mathrm{pp}$ & 99.1 & 1.61 & 0.370 & 2.55 & 1.60 & 0.372 & 2.56 & & \\
\hline $\mathrm{CHI}$ & $\mathrm{pp}$ & 101.5 & 2.24 & 0.121 & 2.55 & 2.24 & 0.123 & 2.55 & & \\
\hline
\end{tabular}

* $R$ specifies red alteration of sample, which is about $2 \mathrm{~cm}$ above the sample with green alteration, $G$. 
Table 1-6. Yucca Crest horizontal transect physical properties, dry bulk density, porosity, and particle density calculated using relative-humidity oven and $105^{\circ} \mathrm{C}$ oven-dry weights; saturated hydraulic conductivity and sorptivity calculated from imbibition experiments on relative-humidity-dried samples

\begin{tabular}{|c|c|c|c|c|c|c|c|c|c|}
\hline \multirow[b]{2}{*}{$\begin{array}{c}\text { Sample } \\
\text { ID }\end{array}$} & \multirow[b]{2}{*}{ Lithology } & \multirow[b]{2}{*}{$\begin{array}{l}\text { Transect } \\
\text { dlstance } \\
\text { (m) }\end{array}$} & \multicolumn{3}{|c|}{ Relative-humidity oven dried } & \multicolumn{3}{|c|}{$105^{\circ} \mathrm{C}$ oven dried } & \multirow{2}{*}{$\begin{array}{c}\text { Saturated } \\
\text { hydraullc } \\
\text { conductlvity } \\
(\mathrm{m} / \mathrm{s})\end{array}$} \\
\hline & & & $\begin{array}{l}\text { Dry bulk } \\
\text { density } \\
\left(g / \mathrm{cm}^{3}\right)\end{array}$ & $\begin{array}{l}\text { Porosity } \\
\left(\mathrm{cm}^{3} / \mathrm{cm}^{3}\right)\end{array}$ & $\begin{array}{l}\text { Partlcle } \\
\text { density } \\
\left(g / \mathrm{cm}^{3}\right)\end{array}$ & $\begin{array}{l}\text { Dry bulk } \\
\text { density } \\
\left(\mathrm{g} / \mathrm{cm}^{3}\right)\end{array}$ & $\begin{array}{c}\text { Porosity } \\
\left(\mathrm{cm}^{3} / \mathrm{cm}^{3}\right)\end{array}$ & $\begin{array}{l}\text { Partlcle } \\
\text { density } \\
\left(g / \mathrm{cm}^{3}\right)\end{array}$ & \\
\hline $1 Y$ & cuc & 0.0 & 1.96 & 0.234 & 2.56 & 1.96 & 0.235 & 2.56 & $4.0 \mathrm{E}-08$ \\
\hline $2 Y$ & cuc & 0.0 & 2.21 & 0.115 & 2.49 & 2.20 & 0.123 & 2.51 & \\
\hline $3 Y$ & cuc & 152.4 & 1.87 & 0.282 & 2.60 & 1.87 & 0.284 & 2.61 & \\
\hline $5 Y$ & cuc & 304.8 & 2.04 & 0.182 & 2.49 & 2.03 & 0.186 & 2.50 & \\
\hline $6 Y$ & cuc & 304.8 & 2.02 & 0.191 & 2.50 & 2.02 & 0.193 & 2.51 & 7.7E-09 \\
\hline $7 Y$ & cuc & 457.2 & 1.98 & 0.228 & 2.56 & 1.98 & 0.229 & 2.56 & \\
\hline $8 Y$ & cuc & 457.2 & 1.95 & 0.237 & 2.56 & 1.95 & 0.238 & 2.56 & \\
\hline $9 Y$ & cuc & 609.6 & 2.12 & 0.139 & 2.46 & 2.11 & 0.139 & 2.46 & \\
\hline $13 Y$ & cuc & 914.4 & 1.93 & 0.247 & 2.56 & 1.93 & 0.247 & 2.56 & \\
\hline $14 Y$ & cuc & $1,066.8$ & 2.24 & 0.102 & 2.49 & 2.23 & 0.105 & 2.50 & \\
\hline $15 Y$ & cuc & $1,219.2$ & 1.86 & 0.273 & 2.55 & 1.86 & 0.273 & 2.55 & \\
\hline $16 Y$ & cuc & $1,219.2$ & 1.84 & 0.281 & 2.56 & 1.84 & 0.283 & 2.57 & \\
\hline $17 Y$ & cuc & $1,371.6$ & 1.94 & 0.240 & 2.56 & 1.94 & 0.241 & 2.56 & \\
\hline $18 Y$ & cuc & $1,371.6$ & 1.90 & 0.233 & 2.48 & 1.90 & 0.234 & 2.48 & \\
\hline $19 Y$ & cuc & $1,524.0$ & 2.02 & 0.208 & 2.55 & 2.02 & 0.208 & 2.55 & \\
\hline $20 Y$ & cuc & $1,676.4$ & 1.89 & 0.262 & 2.57 & 1.89 & 0.263 & 2.57 & \\
\hline $21 Y$ & cuc & $1,828.8$ & 2.02 & 0.212 & 2.57 & 2.02 & 0.212 & 2.57 & \\
\hline $22 Y$ & cuc & $1,981.2$ & 2.08 & 0.192 & 2.57 & 2.07 & 0.195 & 2.57 & \\
\hline $30 Y$ & cuc & $3,200.4$ & 1.89 & 0.264 & 2.56 & 1.89 & 0.265 & 2.57 & 1.4E-07 \\
\hline $31 Y$ & cuc & $3,352.8$ & 1.94 & 0.248 & 2.58 & 1.94 & 0.249 & 2.58 & \\
\hline $32 Y$ & cuc & $3,505.2$ & 1.94 & 0.250 & 2.59 & 1.94 & 0.250 & 2.59 & \\
\hline $33 Y$ & cuc & $3,657.6$ & 1.90 & 0.263 & 2.57 & 1.90 & 0.264 & 2.58 & \\
\hline $34 Y$ & cuc & $3,810.0$ & 1.98 & 0.196 & 2.47 & 1.98 & 0.198 & 2.47 & 8.0E-09 \\
\hline $35 Y$ & cuc & $3,962.4$ & 1.82 & 0.301 & 2.60 & 1.81 & 0.303 & 2.60 & \\
\hline $36 Y$ & cuc & $4,114.8$ & 1.87 & 0.281 & 2.60 & 1.87 & 0.282 & 2.61 & \\
\hline $37 Y$ & cuc & $4,267.2$ & 1.83 & 0.280 & 2.54 & 1.83 & 0.280 & 2.55 & \\
\hline $38 Y$ & cuc & $4,419.6$ & 1.95 & 0.222 & 2.51 & 1.95 & 0.223 & 2.51 & 3.7E-08 \\
\hline $39 Y$ & cuc & $4,572.0$ & 1.93 & 0.249 & 2.57 & 1.93 & 0.252 & 2.58 & \\
\hline $40 Y$ & cuc & $4,572.0$ & 1.80 & 0.306 & 2.60 & 1.80 & 0.307 & 2.60 & \\
\hline $41 Y$ & cuc & $4,724.4$ & 2.02 & 0.197 & 2.52 & 2.02 & 0.198 & 2.52 & \\
\hline $42 Y$ & cuc & $4,724.4$ & 1.92 & 0.244 & 2.54 & 1.91 & 0.250 & 2.55 & \\
\hline $43 Y$ & cuc & $4,876.8$ & 1.89 & 0.264 & 2.56 & 1.88 & 0.264 & 2.56 & $9.8 \mathrm{E}-08$ \\
\hline $44 Y$ & cuc & $4,876.8$ & 1.87 & 0.265 & 2.54 & 1.87 & 0.265 & 2.54 & \\
\hline $45 \mathrm{Y}$ & cuc & $5,029.2$ & 1.95 & 0.241 & 2.57 & 1.95 & 0.242 & 2.58 & \\
\hline
\end{tabular}


Table 1-7. Shardy base horizontal transect physical properties, dry bulk density, porosity, and particle density calculated using relative-humidity oven-dry weights and saturated hydraulic conductivity

\begin{tabular}{|c|c|c|c|c|c|c|}
\hline \multirow[b]{2}{*}{ Sample ID } & \multirow[b]{2}{*}{ Lithology } & \multirow{2}{*}{$\begin{array}{l}\text { Transect } \\
\text { distance } \\
\text { (m) }\end{array}$} & \multicolumn{3}{|c|}{ Relative-humidity oven dried } & \multirow{2}{*}{$\begin{array}{c}\text { Saturated } \\
\text { hydraullc } \\
\text { conductivity } \\
(\mathrm{m} / \mathrm{s})\end{array}$} \\
\hline & & & $\begin{array}{l}\text { Dry bulk } \\
\text { density } \\
\left(g / \mathrm{cm}^{3}\right)\end{array}$ & $\begin{array}{l}\text { Porosity } \\
\left(\mathrm{cm}^{3} / \mathrm{cm}^{3}\right)\end{array}$ & $\begin{array}{l}\text { Particle density } \\
\left(\mathrm{g} / \mathrm{cm}^{3}\right)\end{array}$ & \\
\hline $0+00$ & $\mathrm{ccb}$ & 0.0 & 1.42 & 0.391 & 2.33 & $1.8 \mathrm{E}-06$ \\
\hline $1+00$ & $\mathrm{ccb}$ & 30.5 & 1.57 & 0.334 & 2.35 & 7.3E-08 \\
\hline $1+43$ & $\mathrm{ccb}$ & 43.6 & 1.37 & 0.412 & 2.34 & $5.3 \mathrm{E}-06$ \\
\hline $2+05$ & $\mathbf{c c b}$ & 62.5 & 1.32 & 0.430 & 2.32 & 9.3E-06 \\
\hline $2+45$ & $c c b$ & 74.7 & 1.39 & 0.410 & 2.35 & $3.1 E-06$ \\
\hline $2+90$ & $\mathrm{ccb}$ & 88.4 & 1.26 & 0.452 & 2.29 & $9.0 \mathrm{E}-06$ \\
\hline $3+45$ & $c c b$ & 105.2 & 1.36 & 0.411 & 2.30 & $5.3 \mathrm{E}-06$ \\
\hline $3+65$ & $\mathrm{ccb}$ & 111.3 & 1.47 & 0.374 & 2.35 & $2.8 \mathrm{E}-06$ \\
\hline $3+70$ & $\mathrm{ccb}$ & 112.8 & 1.33 & 0.428 & 2.32 & $6.9 E-06$ \\
\hline $3+90$ & $\mathrm{ccb}$ & 118.9 & 1.51 & 0.354 & 2.33 & $1.2 \mathrm{E}-06$ \\
\hline $4+20$ & ccb & 128.0 & 1.38 & 0.408 & 2.32 & $9.6 \mathrm{E}-06$ \\
\hline $4+60$ & ccb & 140.2 & 1.40 & 0.397 & 2.33 & $3.4 \mathrm{E}-06$ \\
\hline $5+00$ & ccb & 152.4 & 1.33 & 0.431 & 2.34 & $6.7 E-06$ \\
\hline $5+75$ & $\mathrm{ccb}$ & 175.3 & 1.35 & 0.418 & 2.33 & 8.3E-06 \\
\hline $5+90$ & $c c b$ & 179.8 & 1.33 & 0.432 & 2.34 & $2.7 E-06$ \\
\hline $6+10$ & $c c b$ & 185.9 & 1.39 & 0.406 & 2.34 & $7.1 \mathrm{E}-06$ \\
\hline $6+45$ & $c c b$ & 196.6 & 1.39 & 0.404 & 2.33 & $2.5 \mathrm{E}-06$ \\
\hline $6+70$ & ccb & 204.2 & 1.53 & 0.355 & 2.37 & $8.4 E-07$ \\
\hline $7+20$ & $c c b$ & 219.5 & 1.27 & 0.451 & 2.31 & $7.2 \mathrm{E}-06$ \\
\hline $7+50$ & $c c b$ & 228.6 & 1.41 & 0.400 & 2.35 & $3.0 \mathrm{E}-06$ \\
\hline $8+40$ & $c c b$ & 256.0 & 1.38 & 0.409 & 2.34 & $4.5 \mathrm{E}-06$ \\
\hline $8+60$ & $c c b$ & 262.1 & 1.32 & 0.438 & 2.35 & 8.8E-06 \\
\hline $8+85$ & $\mathrm{ccb}$ & 269.7 & 1.35 & 0.429 & 2.36 & $2.3 E-06$ \\
\hline $8+90$ & $c c b$ & 271.3 & 1.41 & 0.409 & 2.38 & $1.5 E-06$ \\
\hline $9+00$ & $c c b$ & 274.3 & 1.27 & 0.461 & 2.36 & $5.4 E-06$ \\
\hline $9+80$ & ccb & 298.7 & 1.31 & 0.427 & 2.28 & $5.0 \mathrm{E}-06$ \\
\hline $10+00$ & ccb & 304.8 & 1.31 & 0.435 & 2.33 & 8.7E-06 \\
\hline $10+20$ & $\mathrm{ccb}$ & 310.9 & 1.30 & 0.443 & 2.34 & 8.7E-06 \\
\hline $10+40$ & $c c b$ & 317.0 & 1.53 & 0.355 & 2.37 & $1.4 \mathrm{E}-07$ \\
\hline $10+65$ & $\mathrm{ccb}$ & 324.6 & 1.29 & 0.449 & 2.34 & $3.9 \mathrm{E}-06$ \\
\hline $11+05$ & $\mathrm{ccb}$ & 336.8 & 1.29 & 0.449 & 2.34 & $4.9 E-06$ \\
\hline $11+25$ & $c c b$ & 342.9 & 1.29 & 0.454 & 2.35 & $5.2 \mathrm{E}-06$ \\
\hline $11+45$ & $c c b$ & 349.0 & 1.27 & 0.459 & 2.35 & $2.5 E-06$ \\
\hline $11+65$ & $c c b$ & 355.1 & 1.35 & 0.423 & 2.34 & $2.3 E-06$ \\
\hline $11+90$ & ccb & 362.7 & 1.47 & 0.373 & 2.34 & 3.7E-07 \\
\hline $12+20$ & $\mathrm{ccb}$ & 371.9 & 1.62 & 0.313 & 2.37 & \\
\hline $12+35$ & $\mathrm{ccb}$ & 376.4 & 1.76 & 0.261 & 2.37 & $2.2 E-10$ \\
\hline $12+80$ & $\mathrm{ccb}$ & 390.1 & 1.53 & 0.353 & 2.37 & 4.1E-07 \\
\hline $13+00$ & ccb & 396.2 & 1.34 & 0.429 & 2.35 & $3.6 \mathrm{E}-06$ \\
\hline $13+20$ & $c c b$ & 402.3 & 1.30 & 0.446 & 2.34 & $2.1 \mathrm{E}-06$ \\
\hline $13+70$ & $\mathrm{ccb}$ & 417.6 & 1.34 & 0.432 & 2.37 & $3.2 \mathrm{E}-06$ \\
\hline $13+90$ & $\mathrm{ccb}$ & 423.7 & 1.29 & 0.451 & 2.34 & 4.7E-06 \\
\hline $14+10$ & $\mathrm{ccb}$ & 429.8 & 1.37 & 0.417 & 2.35 & $4.6 \mathrm{E}-07$ \\
\hline
\end{tabular}


Table 1-7. Shardy base horizontal transect physical properties, dry bulk density, porosity, and particle density calculated using relative-humidity oven-dry weights and saturated hydraulic conductivity--Continued

\begin{tabular}{|c|c|c|c|c|c|c|}
\hline \multirow[b]{2}{*}{ Sample ID } & \multirow[b]{2}{*}{ Lithology } & \multirow{2}{*}{$\begin{array}{c}\text { Transect } \\
\text { distance } \\
(\mathrm{m})\end{array}$} & \multicolumn{3}{|c|}{ Relative-humidity oven dried } & \multirow{2}{*}{$\begin{array}{c}\text { Saturated } \\
\text { hydraulic } \\
\text { conductivity } \\
(\mathbf{m} / \mathbf{s})\end{array}$} \\
\hline & & & $\begin{array}{l}\text { Dry bulk } \\
\text { density } \\
\left(g / \mathrm{cm}^{3}\right)\end{array}$ & $\begin{array}{l}\text { Porosity } \\
\left(\mathrm{cm}^{3} / \mathrm{cm}^{3}\right)\end{array}$ & $\begin{array}{l}\text { Particle density } \\
\left(g^{\prime} \mathrm{cm}^{3}\right)\end{array}$ & \\
\hline $14+30$ & ccb & 435.9 & 1.34 & 0.429 & 2.34 & $9.4 \mathrm{E}-07$ \\
\hline $14+50$ & ccb & 442.0 & 1.44 & 0.377 & 2.31 & 7.3E-07 \\
\hline $14+70$ & $\mathrm{ccb}$ & 448.1 & 1.40 & 0.400 & 2.33 & $4.5 \mathrm{E}-06$ \\
\hline $14+95$ & $\mathbf{c c b}$ & 455.7 & 1.32 & 0.432 & 2.33 & 7.3E-06 \\
\hline $15+15$ & ccb & 461.8 & 1.42 & 0.388 & 2.32 & $5.2 \mathrm{E}-06$ \\
\hline $15+40$ & ccb & 469.4 & 1.86 & 0.222 & 2.39 & $4.8 \mathrm{E}-11$ \\
\hline $15+70$ & ccb & 478.5 & 1.70 & 0.283 & 2.37 & $1.6 \mathrm{E}-08$ \\
\hline $16+20$ & ccb & 493.8 & 1.58 & 0.334 & 2.37 & $1.1 \mathrm{E}-07$ \\
\hline $16+40$ & ccb & 499.9 & 1.53 & 0.352 & 2.36 & $5.2 \mathrm{E}-07$ \\
\hline $16+65$ & ccb & 507.5 & 1.53 & 0.348 & 2.35 & $1.2 \mathrm{E}-07$ \\
\hline $16+85$ & ccb & 513.6 & 1.35 & 0.426 & 2.36 & 2.7E-06 \\
\hline $17+05$ & ccb & 519.7 & 1.43 & 0.393 & 2.35 & 4.5E-06 \\
\hline $17+25$ & ccb & 525.8 & 1.35 & 0.430 & 2.36 & 3.3E-06 \\
\hline $20+85$ & ccb & 635.5 & 1.35 & 0.411 & 2.28 & $5.3 \mathrm{E}-06$ \\
\hline $21+05$ & ccb & 641.6 & 1.40 & 0.393 & 2.30 & $5.9 \mathrm{E}-06$ \\
\hline $21+40$ & ccb & 652.3 & 1.44 & 0.391 & 2.36 & 3.1E-07 \\
\hline $21+75$ & ccb & 662.9 & 1.32 & 0.434 & 2.34 & $5.4 \mathrm{E}-06$ \\
\hline $21+95$ & ccb & 669.0 & 1.32 & 0.434 & 2.33 & $8.7 \mathrm{E}-06$ \\
\hline $22+15$ & ccb & 675.1 & 1.37 & 0.397 & 2.28 & $2.9 \mathrm{E}-06$ \\
\hline $22+60$ & ccb & 688.8 & 1.35 & 0.414 & 2.31 & 8.4E-06 \\
\hline $22+80$ & ccb & 694.9 & 1.35 & 0.413 & 2.30 & $1.0 \mathrm{E}-05$ \\
\hline $23+00$ & ccb & 701.0 & 1.32 & 0.421 & 2.28 & $6.5 \mathrm{E}-06$ \\
\hline
\end{tabular}


Table 1-8. Topopah Spring Tuff vitric caprock horizontal transect physical properties, dry bulk density, porosity, and particle density calculated using relative-humidity oven and $105^{\circ} \mathrm{C}$ oven-dry weights; saturated hydraulic conductivity and sorptivity calculated using imbibition experiments on relative-humidity-dried samples. Transect distance is zero at borehole USW-UZ6s, and positive is north.

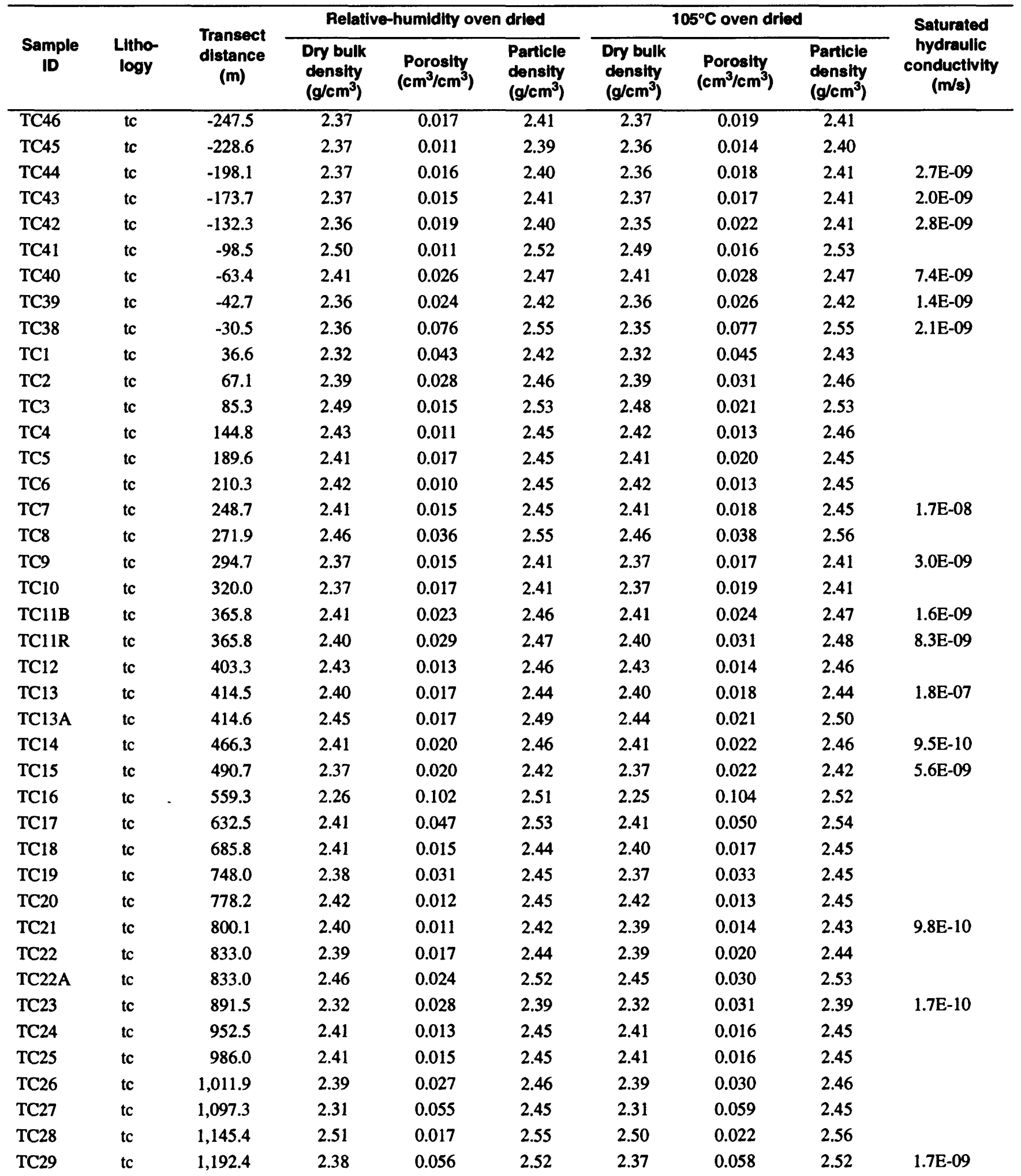


Table 1-8. Topopah Spring Tuff vitric caprock horizontal transect physical properties, dry bulk density, porosity, and particle density calculated using relative-humidity oven and $105^{\circ} \mathrm{C}$ oven-dry weights; saturated hydraulic conductivity and sorptivity calculated using imbibition experiments on relative-humidity-dried samples. Transect distance is zero at borehole USW-UZ6s, and positive is north.--Continued

\begin{tabular}{|c|c|c|c|c|c|c|c|c|c|}
\hline \multirow[b]{2}{*}{$\begin{array}{c}\text { Sample } \\
\text { ID }\end{array}$} & \multirow[b]{2}{*}{$\begin{array}{l}\text { Litho- } \\
\text { logy }\end{array}$} & \multirow[b]{2}{*}{$\begin{array}{l}\text { Transect } \\
\text { distance } \\
(m)\end{array}$} & \multicolumn{3}{|c|}{ Relatlve-humidity oven drlod } & \multicolumn{3}{|c|}{$105^{\circ} \mathrm{C}$ oven dried } & \multirow{2}{*}{$\begin{array}{c}\text { Saturated } \\
\text { hydraulic } \\
\text { conductivlty } \\
(\mathrm{m} / \mathrm{s})\end{array}$} \\
\hline & & & $\begin{array}{l}\text { Dry bulk } \\
\text { density } \\
\left(g / \mathrm{cm}^{3}\right)\end{array}$ & $\begin{array}{l}\text { Porosity } \\
\left(\mathrm{cm}^{3} / \mathrm{cm}^{3}\right)\end{array}$ & $\begin{array}{l}\text { Particle } \\
\text { density } \\
\left(g / \mathrm{cm}^{3}\right)\end{array}$ & $\begin{array}{l}\text { Dry bulk } \\
\text { density } \\
\left(9 / \mathrm{cm}^{3}\right)\end{array}$ & $\begin{array}{l}\text { Porosity } \\
\left(\mathrm{cm}^{3} / \mathrm{cm}^{3}\right)\end{array}$ & $\begin{array}{l}\text { Particle } \\
\text { density } \\
\left(g / \mathrm{cm}^{3}\right)\end{array}$ & \\
\hline TC30 & tc & $1,255.8$ & 2.40 & 0.059 & 2.55 & 2.40 & 0.061 & 2.55 & \\
\hline TC31 & tc & $1,345.7$ & 2.42 & 0.021 & 2.47 & 2.42 & 0.023 & 2.47 & $7.0 \mathrm{E}-10$ \\
\hline TC32 & tc & $1,365.5$ & 2.51 & 0.011 & 2.54 & 2.51 & 0.016 & 2.55 & \\
\hline TC33 & tc & $1,443.2$ & 2.50 & 0.026 & 2.56 & 2.49 & 0.028 & 2.57 & \\
\hline TC34 & tc & $1,446.9$ & 2.36 & 0.023 & 2.41 & 2.35 & 0.026 & 2.42 & \\
\hline TC35 & tc & $1,492.0$ & 2.37 & 0.030 & 2.45 & 2.37 & 0.032 & 2.45 & 2.7E-09 \\
\hline TC36 & tc & $1,524.0$ & 2.39 & 0.015 & 2.42 & 2.38 & 0.018 & 2.43 & \\
\hline TC37B & tc & $1,575.8$ & 2.43 & 0.021 & 2.48 & 2.43 & 0.025 & 2.49 & 2.7E-09 \\
\hline TC37R & tc & $1,575.8$ & 2.40 & 0.014 & 2.43 & 2.40 & 0.016 & 2.44 & \\
\hline
\end{tabular}




\section{APPENDIX II: MOISTURE-RETENTION MEASUREMENTS FOR SUBSAMPLES OF 41 OUTCROP TRANSECT CORES}


Appendix II. Moisture-retention measurements for subsamples of 41 outcrop transect core. Data are listed as volumetric water content (VWC) versus the absolute value of water potential (BARS)

\begin{tabular}{|c|c|c|c|c|c|c|c|c|c|}
\hline \multicolumn{2}{|c|}{ PW198 } & \multicolumn{2}{|c|}{ TPC528 } & \multicolumn{2}{|c|}{ TPC35s } & \multicolumn{2}{|c|}{ TPC27s } & \multicolumn{2}{|c|}{ TPC15s } \\
\hline VWC & BARS & VWC & BARS & VWC & BARS & VWC & BARS & VWC & BARS \\
\hline 0.105 & 0.1 & 0.108 & 0.1 & 0.081 & 0.1 & 0.115 & 0.1 & 0.08 & 0.1 \\
\hline 0.094 & 1.4 & 0.095 & 2.7 & 0.071 & 2.8 & 0.105 & 2.8 & 0.07 & 2.8 \\
\hline 0.076 & 2.8 & 0.089 & 2.8 & 0.063 & 4.1 & 0.071 & 8.3 & 0.07 & 4.8 \\
\hline 0.056 & 4.2 & 0.071 & 5.5 & 0.058 & 9.8 & 0.089 & 8.4 & 0.06 & 9.8 \\
\hline 0.051 & 5.6 & 0.078 & 7.0 & 0.050 & 12.5 & 0.058 & 12.4 & 0.05 & 21.0 \\
\hline 0.069 & 5.6 & 0.060 & 8.3 & 0.046 & 19.6 & 0.065 & 16.8 & 0.05 & 29.4 \\
\hline 0.044 & 6.9 & 0.067 & 8.3 & 0.040 & 34.8 & 0.040 & 27.7 & 0.04 & 43.3 \\
\hline 0.038 & 20.7 & 0.053 & 15.1 & 0.035 & 59.0 & 0.033 & 44.7 & 0.04 & 69.0 \\
\hline 0.031 & 56.1 & 0.046 & 29.2 & 0.031 & 95.3 & 0.022 & 110.3 & 0.03 & 138.7 \\
\hline 0.029 & 102.8 & 0.040 & 43.3 & 0.027 & 134.4 & 0.015 & 290.2 & 0.03 & 201.2 \\
\hline 0.018 & 428.1 & 0.035 & 64.8 & 0.022 & 249.9 & 0.008 & 680.8 & 0.02 & 264.9 \\
\hline 0.014 & 489.1 & 0.025 & 194.8 & 0.016 & 437.2 & 0.006 & 838.2 & 0.01 & 569.8 \\
\hline 0.007 & $1,124.6$ & 0.019 & 369.2 & 0.012 & 656.5 & 0.005 & $1,302.0$ & 0.01 & 733.9 \\
\hline 0.005 & $1,439.6$ & 0.006 & $1,342.7$ & 0.006 & $1,315.3$ & 0.005 & $1,522.7$ & 0.01 & $1,114.0$ \\
\hline 0.004 & $1,648.4$ & 0.004 & $1,648.4$ & 0.005 & $1,635.9$ & 0.007 & & & $1,300.0$ \\
\hline \multicolumn{2}{|c|}{ TPC98 } & \multicolumn{2}{|c|}{ TPC58 } & \multicolumn{2}{|c|}{ TPC2s } & \multicolumn{2}{|c|}{ TPC18 } & \multicolumn{2}{|c|}{ BT27Hs } \\
\hline VWC & BARS & VWC & BARS & VWC & BARS & VWC & BARS & VWC & BARS \\
\hline 0.032 & 0.1 & 0.035 & 0.1 & 0.042 & 0.1 & 0.120 & 0.1 & 0.21 & 0.1 \\
\hline 0.029 & 20.8 & 0.030 & 101.0 & 0.038 & 9.7 & 0.110 & 4.1 & 0.20 & 4.2 \\
\hline 0.022 & 90.0 & 0.027 & 201.0 & 0.035 & 54.8 & 0.102 & 12.5 & 0.19 & 4.1 \\
\hline 0.018 & 372.0 & 0.024 & 568.0 & 0.031 & 240.0 & 0.095 & 22.5 & 0.18 & 4.2 \\
\hline 0.008 & $1,319.0$ & 0.023 & 627.1 & 0.029 & 310.0 & 0.089 & 49.3 & 0.16 & 7.0 \\
\hline 0.008 & $1,042.0$ & 0.020 & $1,098.0$ & 0.026 & 373.0 & 0.085 & 66.8 & 0.14 & 26.3 \\
\hline \multirow[t]{9}{*}{0.006} & $1,572.0$ & 0.019 & $1,058.3$ & 0.021 & 466.0 & 0.078 & 73.0 & 0.13 & 48.0 \\
\hline & & 0.015 & $2,158.1$ & & & 0.074 & 76.3 & 0.10 & 203.2 \\
\hline & & & & & & 0.066 & 105.7 & 0.09 & 255.1 \\
\hline & & & & & & 0.063 & 137.4 & 0.04 & $2,592.1$ \\
\hline & & & & & & 0.057 & 199.6 & & \\
\hline & & & & & & 0.044 & 477.7 & & \\
\hline & & & & & & 0.037 & 617.2 & & \\
\hline & & & & & & 0.028 & $1,010.2$ & & \\
\hline & & & & & & 0.026 & $1,218.3$ & & \\
\hline \multicolumn{2}{|c|}{ BT26Hs } & \multicolumn{2}{|c|}{ BT25Hs } & \multicolumn{2}{|c|}{ BT24Hs } & \multicolumn{2}{|c|}{ BT23-1Hs } & \multicolumn{2}{|c|}{ ВT22Hs } \\
\hline VWC & BARS & VWC & BARS & VWC & BARS & VwC & BARS & VWC & BARS \\
\hline 0.235 & 0.1 & 0.346 & 0.1 & 0.406 & 0.1 & 0.411 & 0.1 & 0.43 & 0.1 \\
\hline 0.224 & 1.4 & 0.321 & 1.4 & 0.388 & 1.4 & 0.392 & 1.4 & 0.40 & 1.4 \\
\hline 0.215 & 2.8 & 0.229 & 1.4 & 0.364 & 1.4 & 0.326 & 4.2 & 0.33 & 1.4 \\
\hline 0.175 & 4.2 & 0.219 & 2.8 & 0.331 & 2.8 & 0.237 & 1.4 & 0.28 & 1.4 \\
\hline 0.175 & 8.4 & 0.193 & 4.2 & 0.268 & 1.4 & 0.176 & 1.4 & 0.20 & 2.8 \\
\hline 0.114 & 26.2 & 0.184 & 2.8 & 0.186 & 4.2 & 0.126 & 4.2 & 0.15 & 5.6 \\
\hline 0.082 & 130.3 & 0.175 & 8.4 & 0.127 & 4.2 & 0.104 & 4.2 & 0.13 & 8.3 \\
\hline \multirow[t]{3}{*}{0.038} & 990.6 & 0.097 & 35.2 & 0.105 & 8.4 & 0.093 & 9.8 & 0.06 & 124.7 \\
\hline & & 0.024 & $2,953.2$ & 0.056 & 46.6 & 0.055 & 48.0 & 0.04 & 917.0 \\
\hline & & & & 0.015 & $2,943.7$ & 0.019 & $2,727.2$ & & \\
\hline
\end{tabular}


Appendix II. Moisture-retention measurements for subsamples of 41 outcrop transect core. Data are listed as volumetric water content (VWC) versus the absolute value of water potential (BARS)--Continued

\begin{tabular}{|c|c|c|c|c|c|c|c|c|c|}
\hline \multicolumn{2}{|c|}{ BT18Hs } & \multicolumn{2}{|c|}{ BT17s } & \multicolumn{2}{|c|}{ BT11s } & \multicolumn{2}{|c|}{ BT3Vs } & \multicolumn{2}{|c|}{ BT2s } \\
\hline VwC & BARS & VWC & BARS & vwC & BARS & VwC & BARS & VwC & BARS \\
\hline 0.442 & 0.1 & 0.442 & 0.1 & 0.628 & 0.1 & 0.381 & 0.1 & 0.06 & 0.1 \\
\hline 0.420 & 1.4 & 0.414 & 2.8 & 0.572 & 1.4 & 0.327 & 1.4 & 0.05 & 1.4 \\
\hline 0.370 & 1.4 & 0.372 & 2.8 & 0.516 & 1.4 & 0.259 & 1.4 & 0.04 & 1.4 \\
\hline 0.361 & 1.4 & 0.347 & 2.8 & 0.463 & 4.2 & 0.158 & 1.4 & 0.04 & 5.6 \\
\hline 0.288 & 2.8 & 0.183 & 2.8 & 0.322 & 4.2 & 0.101 & 2.8 & 0.03 & 12.5 \\
\hline 0.174 & 4.2 & 0.150 & 7.0 & 0.194 & 5.6 & 0.096 & 5.6 & 0.02 & 384.0 \\
\hline 0.151 & 5.6 & 0.134 & 12.6 & 0.073 & 43.7 & 0.064 & 7.0 & 0.02 & 428.0 \\
\hline 0.136 & 8.4 & 0.090 & 69.8 & 0.012 & $2,281.5$ & 0.021 & 123.2 & 0.01 & 489.0 \\
\hline 0.076 & 43.7 & 0.022 & $2,723.8$ & & & 0.006 & $1,071.2$ & 0.01 & 376.1 \\
\hline \multirow[t]{2}{*}{0.022} & $2,863.4$ & & & & & & & 0.01 & 877.3 \\
\hline & & & & & & & & 0.01 & $1,261.8$ \\
\hline \multicolumn{2}{|c|}{ BT1s } & \multicolumn{2}{|c|}{ TS58s } & \multicolumn{2}{|c|}{ TS56s } & \multicolumn{2}{|c|}{ TS54s } & \multicolumn{2}{|c|}{ TS50s } \\
\hline vwC & BARS & VwC & BARS & VwC & BARS & vwC & BARS & VwC & BARS \\
\hline 0.045 & 0.1 & 0.124 & 0.1 & 0.184 & 0.1 & 0.120 & 0.1 & 0.18 & 0.1 \\
\hline 0.037 & 1.4 & 0.109 & 1.4 & 0.156 & 2.8 & 0.104 & 2.8 & 0.14 & 2.8 \\
\hline 0.024 & 8.3 & 0.089 & 2.8 & 0.141 & 1.4 & 0.083 & 2.8 & 0.13 & 2.8 \\
\hline 0.023 & 22.4 & 0.084 & 2.8 & 0.132 & 2.8 & 0.076 & 5.5 & 0.11 & 2.8 \\
\hline 0.017 & 450.0 & 0.057 & 4.2 & 0.121 & 1.4 & 0.071 & 2.8 & 0.09 & 4.2 \\
\hline \multirow[t]{6}{*}{0.010} & 747.0 & 0.046 & 12.5 & 0.112 & 1.4 & 0.052 & 11.1 & 0.04 & 12.6 \\
\hline & & 0.038 & 38.0 & 0.086 & 5.6 & 0.046 & 5.6 & 0.02 & 171.4 \\
\hline & & 0.022 & 343.5 & 0.078 & 4.2 & 0.041 & 15.4 & 0.00 & $1,052.0$ \\
\hline & & 0.015 & 553.8 & 0.069 & 8.4 & 0.034 & 68.3 & 0.03 & 313.7 \\
\hline & & & & 0.051 & 21.0 & 0.018 & 340.9 & 0.01 & $2,360.1$ \\
\hline & & & & 0.024 & 138.4 & 0.010 & 488.9 & & \\
\hline \multicolumn{2}{|c|}{ TS47s } & \multicolumn{2}{|c|}{ TS40s } & \multicolumn{2}{|c|}{ TS32s } & \multicolumn{2}{|c|}{ TS29s } & \multicolumn{2}{|c|}{ TS26s } \\
\hline VwC & BARS & VwC & BARS & vwC & BARS & vwC & BARS & VWC & BARS \\
\hline 0.185 & 0.1 & 0.156 & 0.1 & 0.115 & 0.1 & 0.140 & 0.1 & 0.13 & 0.1 \\
\hline 0.158 & 4.1 & 0.139 & 1.4 & 0.092 & 5.5 & 0.124 & 4.1 & 0.12 & 1.4 \\
\hline 0.132 & 4.2 & 0.131 & 1.4 & 0.085 & 6.8 & 0.112 & 4.1 & 0.10 & 4.2 \\
\hline 0.125 & 5.5 & 0.120 & 4.2 & 0.076 & 8.4 & 0.106 & 4.2 & 0.09 & 2.8 \\
\hline 0.107 & 4.8 & 0.110 & 4.1 & 0.067 & 22.2 & 0.079 & 8.4 & 0.08 & 4.2 \\
\hline 0.074 & 5.6 & 0.092 & 4.1 & 0.051 & 55.2 & 0.074 & 5.6 & 0.06 & 4.2 \\
\hline 0.067 & 7.0 & 0.070 & 8.3 & 0.044 & 90.2 & 0.069 & 5.6 & 0.05 & 9.8 \\
\hline 0.040 & 21.7 & 0.070 & 8.4 & 0.028 & 363.8 & 0.063 & 8.3 & 0.04 & 48.0 \\
\hline 0.022 & 98.8 & 0.042 & 29.5 & 0.007 & $2,305.2$ & 0.045 & 30.9 & 0.02 & 265.1 \\
\hline \multirow[t]{2}{*}{0.006} & $1,697.8$ & 0.013 & 410.8 & & & 0.027 & 131.8 & 0.01 & 682.4 \\
\hline & & 0.007 & $1,709.0$ & & & 0.010 & $1,013.7$ & & \\
\hline
\end{tabular}


Appendix II. Moisture-retention measurements for subsamples of 41 outcrop transect core. Data are listed as volumetric water content (VWC) versus the absolute value of water potential (BARS)--Continued

\begin{tabular}{|c|c|c|c|c|c|c|c|c|c|}
\hline \multicolumn{2}{|c|}{ BB68s } & \multicolumn{2}{|c|}{ BB64s } & \multicolumn{2}{|c|}{ BB45s } & \multicolumn{2}{|c|}{ BB31s } & \multicolumn{2}{|c|}{ BB16s } \\
\hline vwC & BARS & VWC & BARS & VWC & BARS & vwC & BARS & VWC & BARS \\
\hline 0.078 & 0.1 & 0.192 & 0.1 & 0.141 & 0.1 & 0.099 & 0.1 & 0.07 & 0.1 \\
\hline 0.072 & 4.1 & 0.184 & 1.4 & 0.132 & 4.1 & 0.076 & 4.1 & 0.06 & 5.5 \\
\hline 0.057 & 29.2 & 0.174 & 4.2 & 0.112 & 4.1 & 0.067 & 5.5 & 0.05 & 12.4 \\
\hline 0.052 & 40.6 & 0.172 & 4.1 & 0.105 & 5.5 & 0.061 & 5.5 & 0.05 & 13.9 \\
\hline 0.046 & 50.9 & 0.168 & 1.4 & 0.095 & 4.2 & 0.051 & 7.0 & 0.03 & 75.3 \\
\hline 0.038 & 77.6 & 0.166 & 4.2 & 0.087 & 18.0 & 0.043 & 12.4 & 0.03 & 113.0 \\
\hline 0.031 & 175.3 & 0.136 & 2.8 & 0.064 & 48.0 & 0.032 & 52.3 & 0.03 & 180.0 \\
\hline 0.020 & 541.2 & 0.106 & 7.0 & 0.052 & 84.6 & 0.018 & 595.7 & 0.02 & 350.0 \\
\hline \multirow[t]{3}{*}{0.000} & & 0.070 & 20.9 & 0.031 & 313.7 & 0.004 & $2,306.3$ & 0.02 & 388.6 \\
\hline & & 0.039 & 104.5 & 0.013 & $2,360.1$ & & & 0.01 & $2,096.0$ \\
\hline & & 0.005 & $2,524.9$ & & & & & & \\
\hline \multicolumn{2}{|c|}{ BB13As } & \multicolumn{2}{|c|}{ BB5s } & \multicolumn{2}{|c|}{ CH60s } & \multicolumn{2}{|c|}{ CH47s } & \multicolumn{2}{|c|}{ CH44s } \\
\hline vwC & BARS & vwC & BARS & vwC & BARS & vwC & BARS & vwC & BARS \\
\hline 0.079 & 0.1 & 0.022 & 0.1 & 0.357 & 0.1 & 0.322 & 0.1 & 0.34 & 0.1 \\
\hline 0.071 & 5.6 & 0.021 & 13.8 & 0.319 & 1.4 & 0.300 & 1.4 & 0.32 & 1.4 \\
\hline 0.056 & 8.3 & 0.018 & 361.0 & 0.273 & 1.4 & 0.286 & 2.8 & 0.29 & 1.4 \\
\hline 0.050 & 9.6 & 0.014 & 477.0 & 0.224 & 1.4 & 0.266 & 5.6 & 0.26 & 2.8 \\
\hline 0.034 & 16.6 & 0.012 & 677.0 & 0.219 & 4.2 & 0.260 & 4.2 & 0.26 & 1.4 \\
\hline 0.018 & 126.2 & 0.009 & $1,263.0$ & 0.181 & 11.2 & 0.236 & 24.9 & 0.22 & 7.0 \\
\hline 0.016 & 260.2 & 0.008 & $1,582.0$ & 0.176 & 18.2 & 0.188 & 91.9 & 0.16 & 102.3 \\
\hline 0.011 & 728.1 & 0.006 & $1,861.1$ & 0.151 & 39.4 & 0.119 & 873.4 & 0.11 & 890.8 \\
\hline \multirow[t]{2}{*}{0.008} & $1,591.2$ & & & 0.071 & $2,966.0$ & & & 0.02 & 388.6 \\
\hline & & & & 0.013 & $2,360.1$ & & & 0.01 & $2,096.0$ \\
\hline \multicolumn{2}{|c|}{ CH40s } & & & & & & & & \\
\hline vwc & BARS & & & & & & & & \\
\hline 0.401 & 0.1 & & & & & & & & \\
\hline 0.370 & 1.4 & & & & & & & & \\
\hline 0.324 & 2.8 & & & & & & & & \\
\hline 0.312 & 2.8 & & & & & & & & \\
\hline 0.266 & 4.2 & & & & & & & & \\
\hline 0.277 & 4.2 & & & & & & & & \\
\hline 0.269 & 7.0 & & & & & & & & \\
\hline 0.238 & 11.1 & & & & & & & & \\
\hline 0.156 & 94.8 & & & & & & & & \\
\hline 0.106 & 883.4 & & & & & & & & \\
\hline
\end{tabular}




\section{APPENDIX III: GRAPHS OF MOISTURE-RETENTION DATA AND CURVE FITS FOR SUBSAMPLES OF 41 OUTCROP TRANSECT CORES}



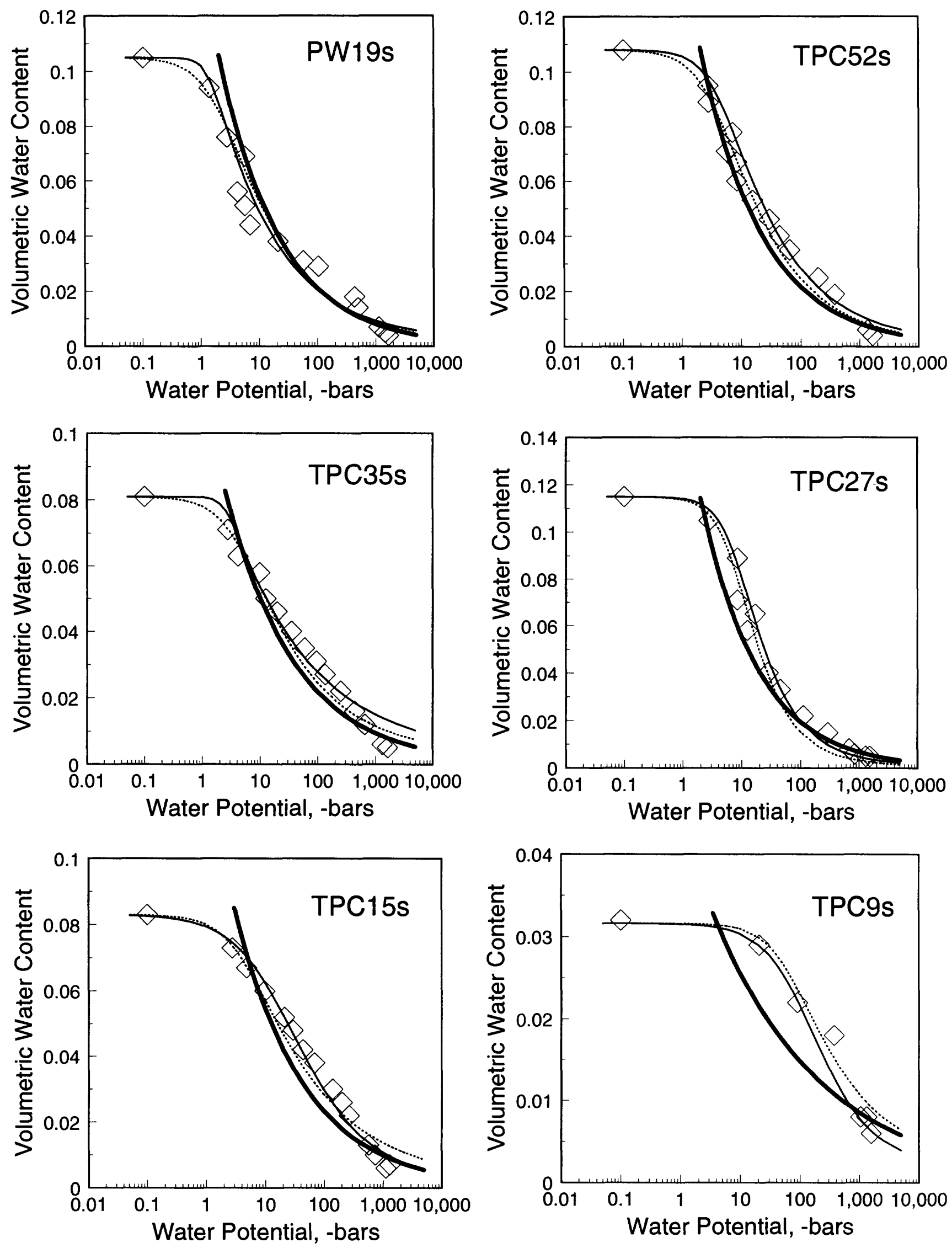

Appendix III. Points are measured data; explanation for models: narrow solid line is van Genuchten using a calculated $m$ value, dotted line is van Genuchten using an estimated $m$ value, and thick solid line is Brooks and Corey. 

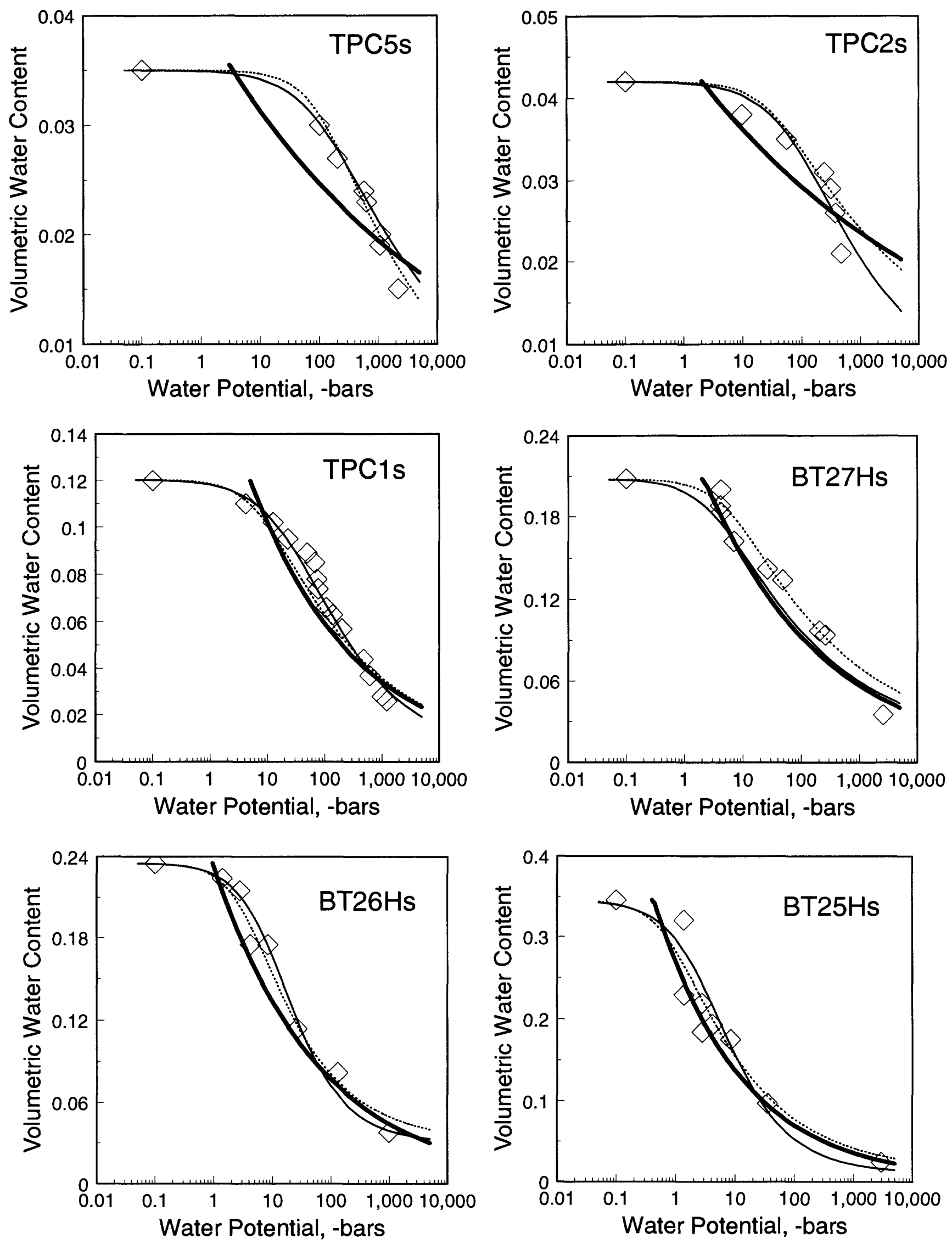

Appendix III. Points are measured data; explanation for models: narrow solid line is van Genuchten using a calculated $m$ value, dotted line is van Genuchten using an estimated $m$ value, and thick solid line is Brooks and Corey.--Continued 

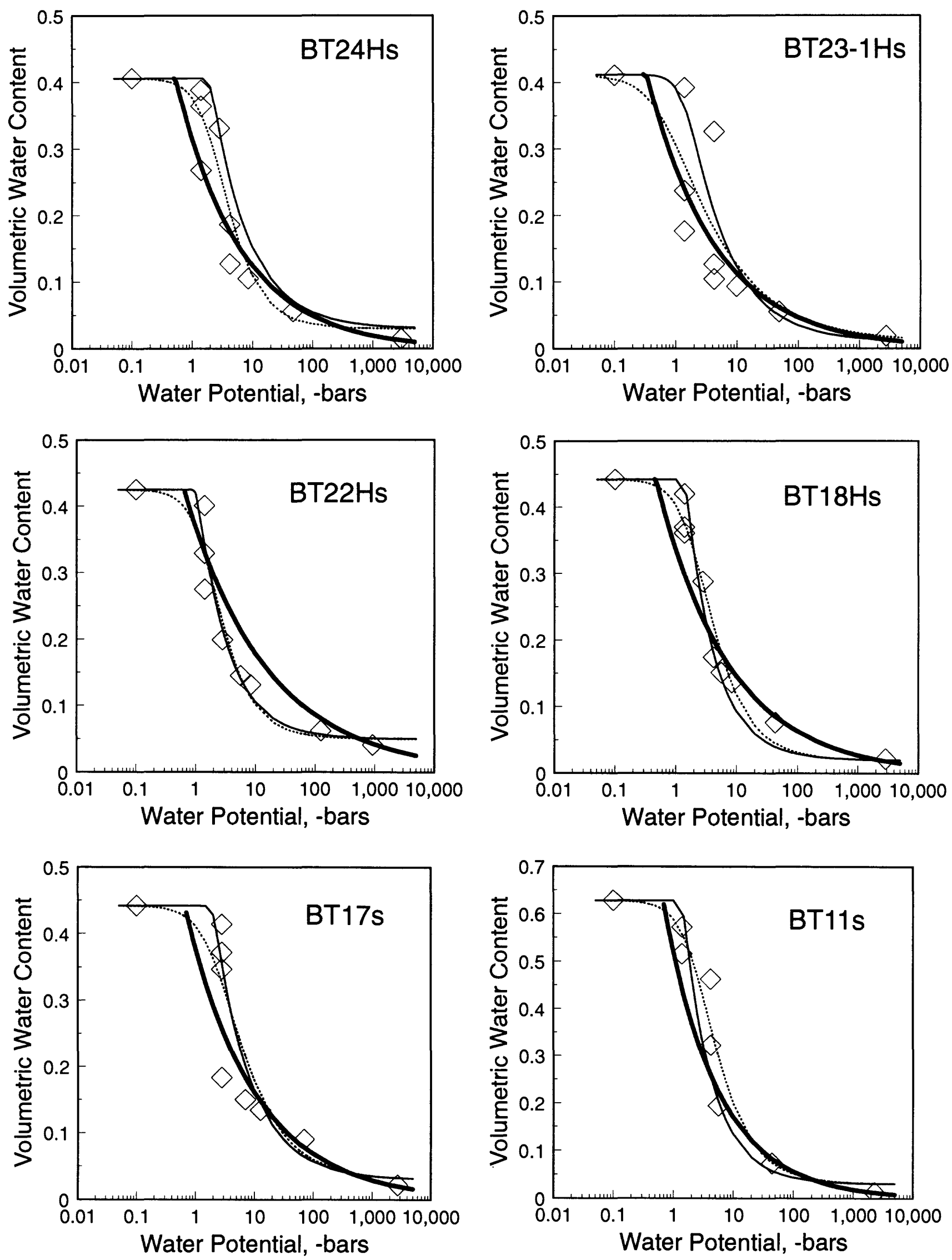

Appendix III. Points are measured data; explanation for models: narrow solid line is van Genuchten using a calculated $m$ value, dotted line is van Genuchten using an estimated $m$ value, and thick solid line is Brooks and Corey.--Continued 

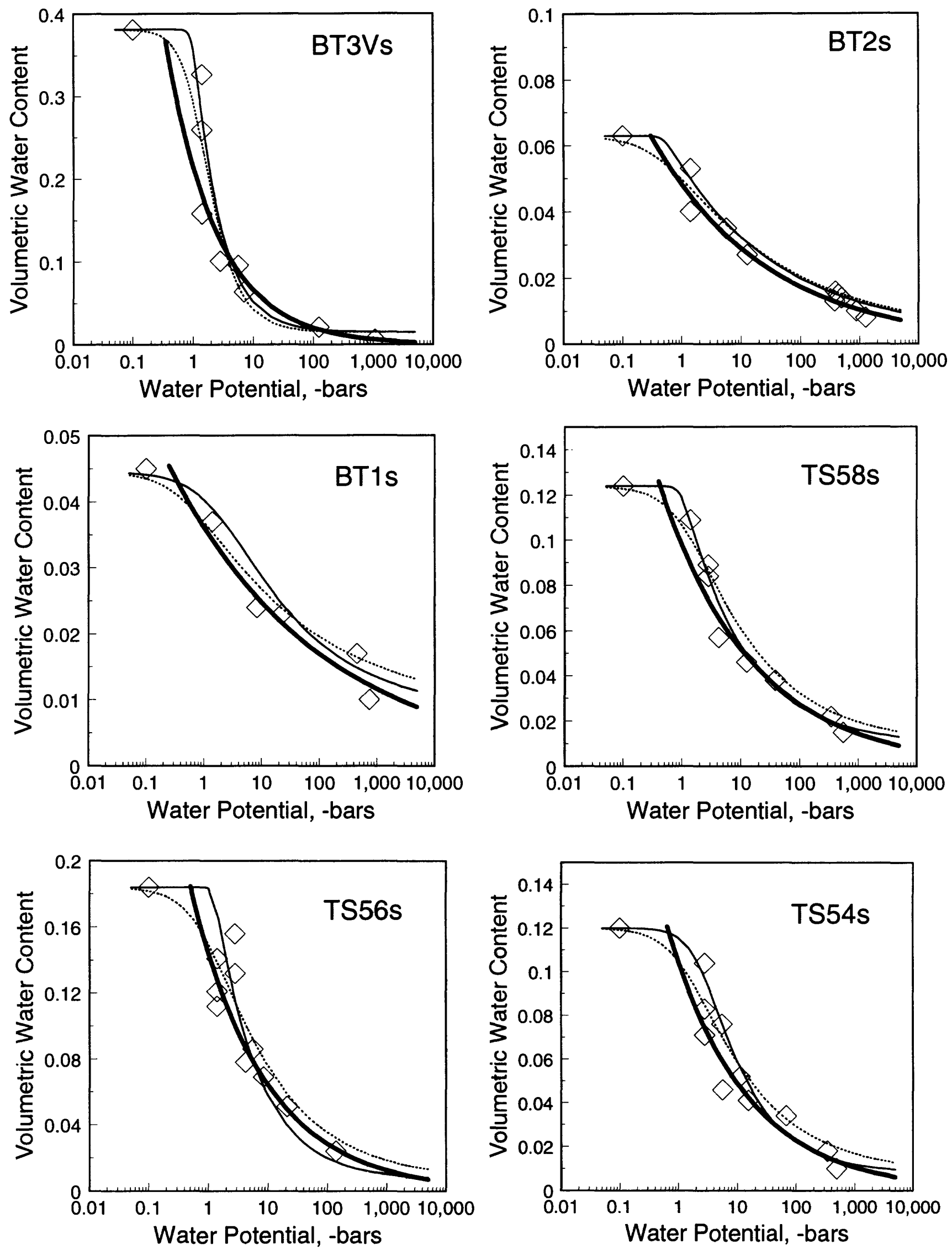

Appendix III. Points are measured data; explanation for models: narrow solid line is van Genuchten using a calculated $m$ value, dotted line is van Genuchten using an estimated $m$ value, and thick solid line is Brooks and Corey.--Continued 

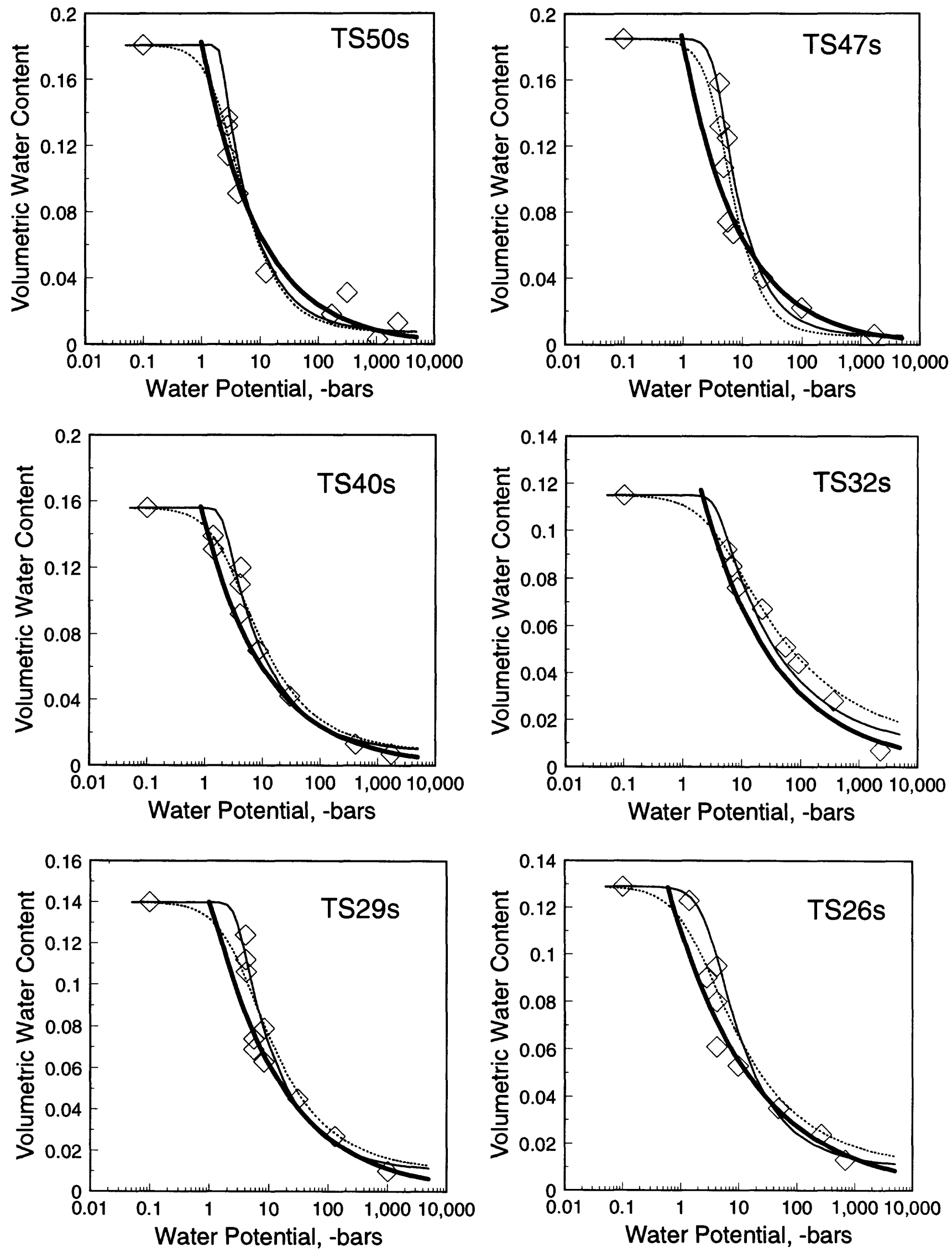

Appendix III. Points are measured data; explanation for models: narrow solid line is van Genuchten using a calculated $m$ value, dotted line is van Genuchten using an estimated $m$ value, and thick solid line is Brooks and Corey.---Continued 

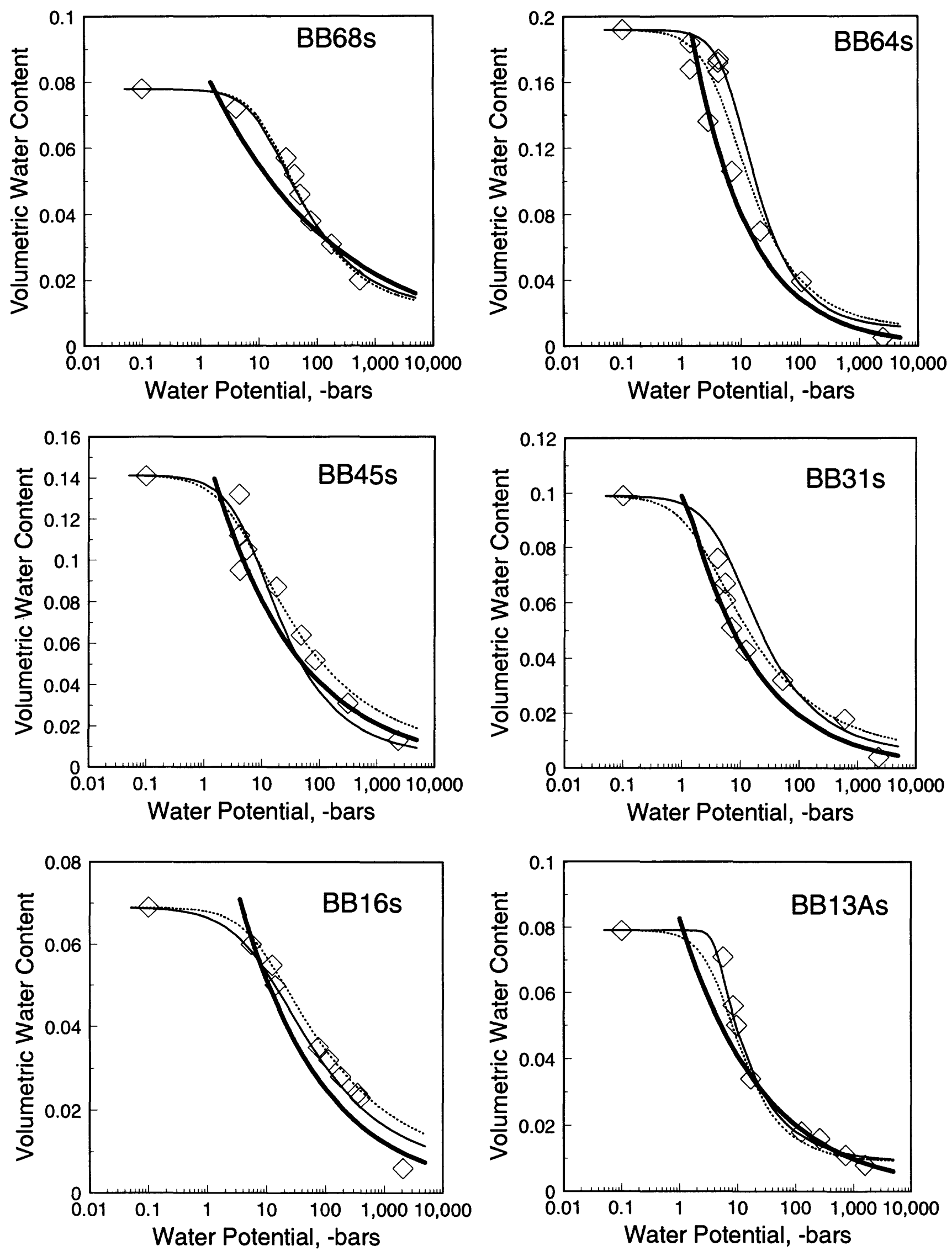

Appendix III. Points are measured data; explanation for models: narrow solid line is van Genuchten using a calculated $m$ value, dotted line is van Genuchten using an estimated $m$ value, and thick solid line is Brooks and Corey.--Continued 

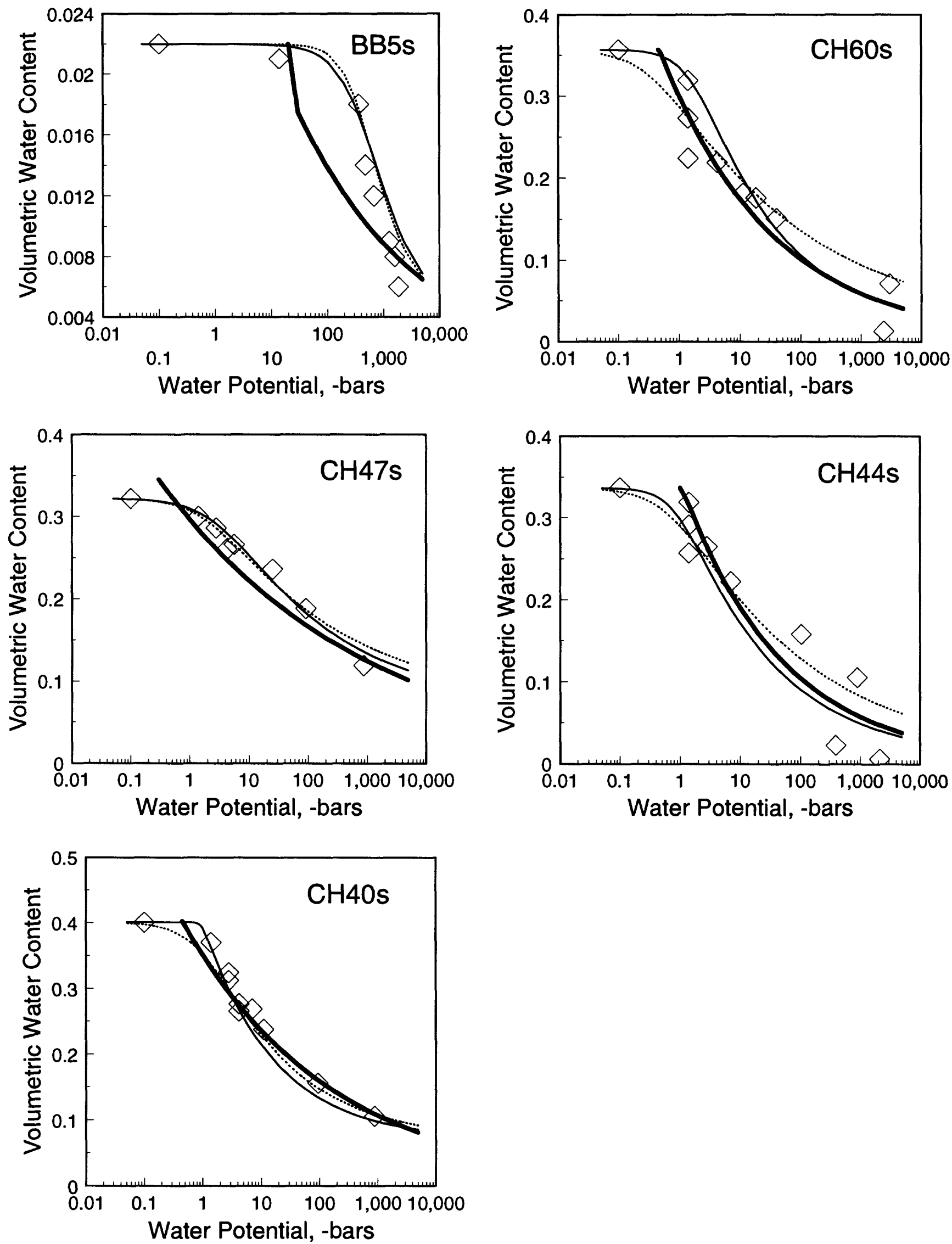

Appendix III. Points are measured data; explanation for models: narrow solid line is van Genuchten using a calculated $m$ value, dotted line is van Genuchten using an estimated $m$ value, and thick solid line is Brooks and Corey.--Continued 